\title{
\#USGS
}

X

Prepared in cooperation with Everglades National Park and Big Cypress National Preserve

\section{Fre History of Everglades National Park and Big Cypress National Preserve, Southern Florida}

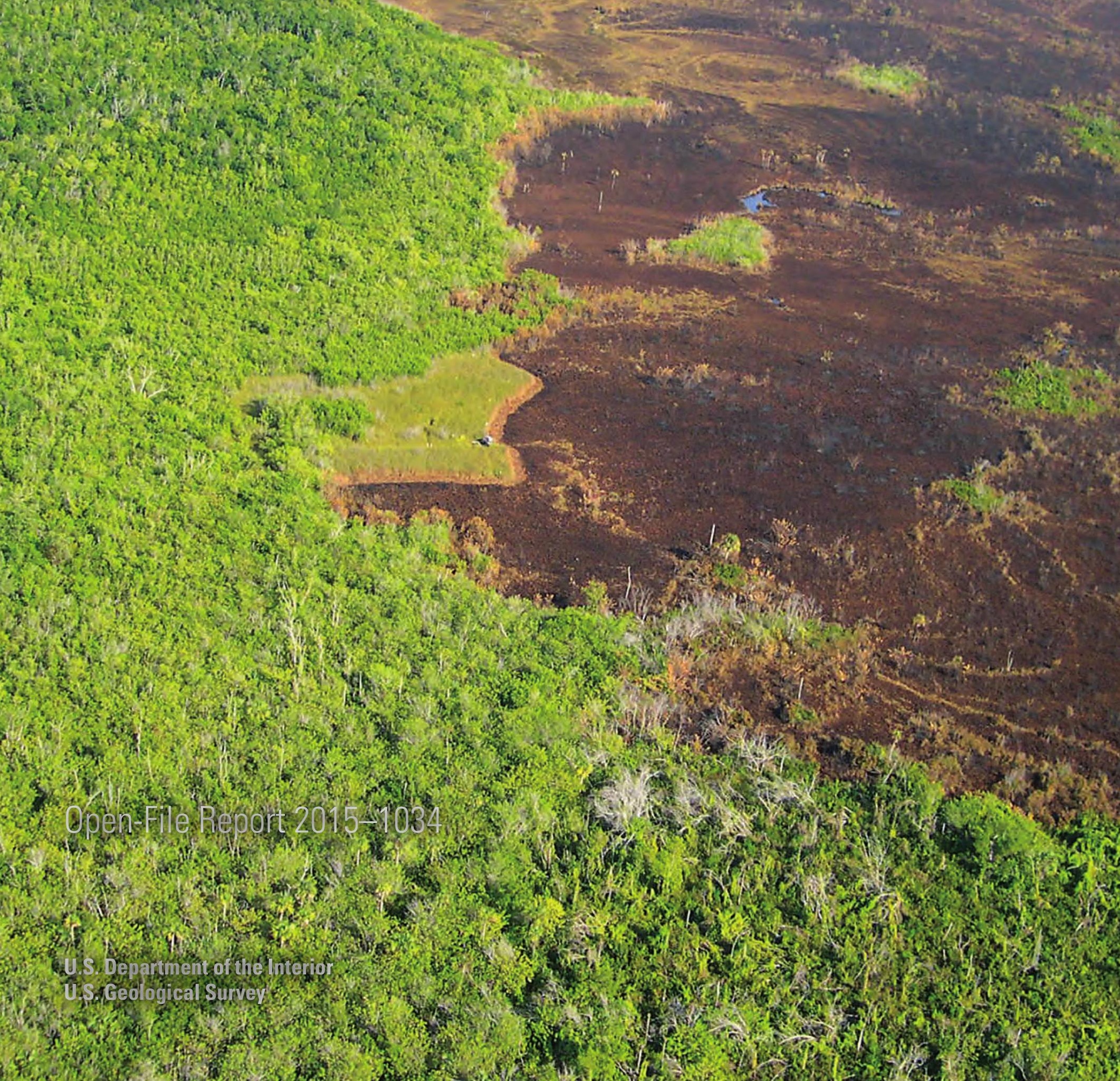


Cover: An oblique aerial photograph of a part of the fire scar left by the Harney River Prescribed Fire \#1 (Everglades National Park fire \#09003), which burned from January 12 to 23, 2009. The fire covered 3,491 acres. It was set for marsh management purposes and to control invasive plants, such as Brazilian pepper (Schinus terebinthifolius) and Old World climbing fern (Lygodium microphyllum). Photograph taken by Thomas J. Smith III, January 14, 2009. 


\section{Fire History of Everglades National Park and Big Cypress National Preserve, Southern Florida}

By Thomas J. Smith III, Ann M. Foster, and John W. Jones

Prepared in cooperation with Everglades National Park and Big Cypress National Preserve

Open-File Report 2015-1034

U.S. Department of the Interior

U.S. Geological Survey 


\section{U.S. Department of the Interior \\ SALLY JEWELL, Secretary}

\section{U.S. Geological Survey \\ Suzette M. Kimball, Acting Director}

U.S. Geological Survey, Reston, Virginia: 2015

For more information on the USGS—-the Federal source for science about the Earth, its natural and living resources, natural hazards, and the environment-visit http://www.usgs.gov or call 1-888-ASK-USGS

For an overview of USGS information products, including maps, imagery, and publications, visit $h t t p: / / w w w . u s g s . g o v / p u b p r o d$

To order this and other USGS information products, visit $h$ ttp://store.usgs.gov

Suggested citation:

Smith, T.J., III, Foster, A.M., and Jones, J.W., 2015, Fire history of Everglades National Park and Big Cypress National Preserve, southern Florida: U.S. Geological Survey Open-File Report 2015-1034, 86 p., http://dx.doi.org/10.3133/ofr20151034.

ISSN 2331-1258 (online)

Any use of trade, product, or firm names is for descriptive purposes only and does not imply endorsement by the U.S. Government.

Although this report is in the public domain, permission must be secured from the individual copyright owners to reproduce any copyrighted material contained within this report. 


\section{Contents}

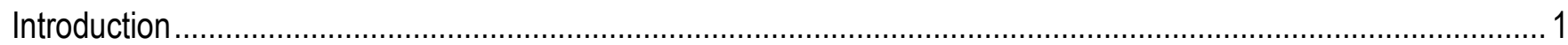

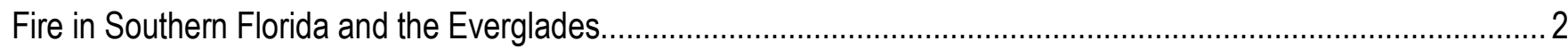

Fire Management in Everglades National Park and the Big Cypress National Preserve ..................................... 4

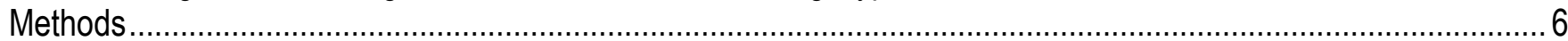

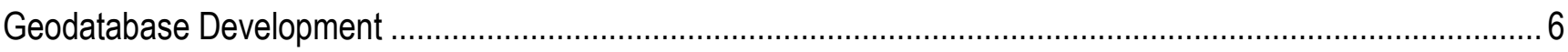

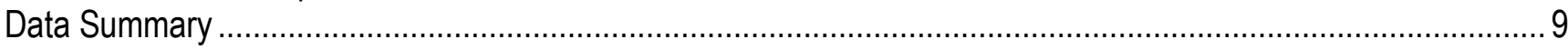

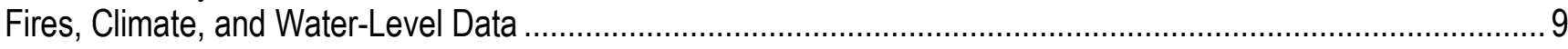

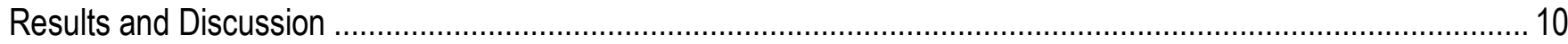

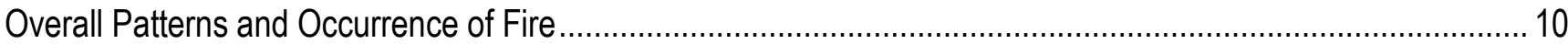

Everglades National Park ……..................................................................................................... 10

Big Cypress National Preserve........................................................................................................ 14

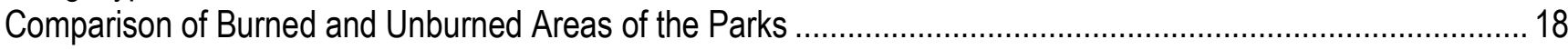

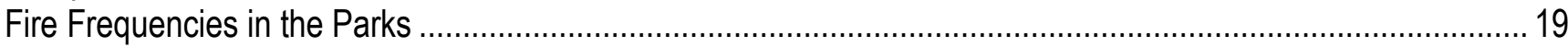

Fires, Climate, and Water Level in Everglades National Park.................................................................... 21

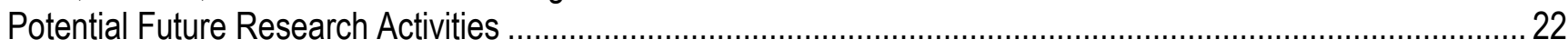

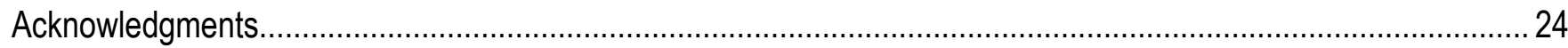

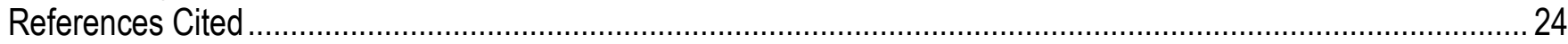

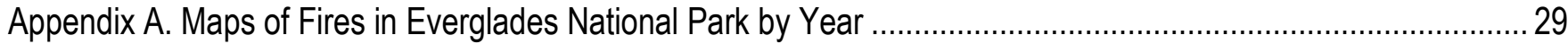

Appendix B. Maps of Fires in Big Cypress National Preserve by Year ..................................................................... 61

Appendix C. Proposed National Park Service Spatial Data Standards for Fire History.............................................78

Appendix D. Fire Project Information and Data Entry Protocol ....................................................................... 84

\section{Figures}

Figure 1. Map showing Everglades National Park and Big Cypress National Preserve, southern Florida ............... 3

Figure 2. Aerial photograph showing fire burning on Cape Sable, southern Florida, 1928 ................................. 4

Figure 3. Examples of methods used to delineate fire perimeters; $(A)$ hand drawn on U.S. Department of the Interior fire reporting form (X's represent the fire ignition points), $(B)$ hand drawn on quadrangle (U.S. Geological Survey 7.5-minute topographic map), (C) controlled burn mapped in great detail by fire management staff at BICY using Global Positioning System, and $(D)$ digitized from a remotely sensed image ............................................. 5

Figure 4. Examples of fires represented as rectangles or circles, north of Lostmans Key, southern Florida .......... 7 Figure 5. Graph showing yearly time series for numbers of "Inside" Suppressed, Natural, and Prescribed fires for Everglades National Park, southern Florida, 1948-2010 ……............................................ 10

Figure 6. Graph showing yearly time series for numbers of "Outside" Suppressed, Natural, and Prescribed fires for Everglades National Park, southern Florida, 1948-2010 .................................................... 11

Figure 7. Graph showing yearly time series of acres burned for "Inside" Suppressed, Natural, and Prescribed fires for Everglades National Park, southern Florida, 1948-2010 .................................................. 12

Figure 8. Graph showing yearly time series of acres burned for "Outside" Suppressed, Natural, and Prescribed fires for Everglades National Park, southern Florida, 1948-2010 .................................................. 12

Figure 9. Graph showing yearly time series of total fires for "Inside" Suppressed, Natural, and Prescribed fires for Big Cypress National Preserve, southern Florida, 1978-2010 .............................................. 14

Figure 10. Graph showing yearly time series of total fires for "Outside" Suppressed, Natural, and Prescribed fires for Big Cypress National Preserve, southern Florida, 1978-2010 ............................................ 15

Figure 11. Graph showing yearly time series of acres burned for "Inside" Suppressed, Natural, and Prescribed fires for Big Cypress National Preserve, southern Florida, 1978-2010. 
Figure 12. Graph showing yearly time series of acres burned for "Outside" Suppressed, Natural, and Prescribed fires for Big Cypress National Preserve, southern Florida, 1978-2010.

Figure 13. Maps showing unburned areas of Big Cypress National Preserve (BICY; left) and

Everglades National Park, (EVER; right), southern Florida, based on combined fire history data

from BICY (1978-2010) and ENP (1948-2010)

Figure 14. Maps showing total fire frequency based on data from fire management staff at Big Cypress

National Preserve, 1978-2010 (left) and Everglades National Park, 1948-2010 (right), southern Florida ....

Figure 15. Maps showing total fire frequency by type based on data provided by fire management staff at

Big Cypress National Preserve, 1978-2010, southern Florida .

Figure 16. Maps showing total fire frequency by type based on data provided by fire management staff at

Everglades National Park, 1948-2010, southern Florida...

Figure 17. Graph showing total number of fires compared to March-June water levels at Everglades Depth

Estimation Network station P33, Everglades National Park, 1948-2010, southern Florida

Figure 18. Graph showing total area burned compared to March-June water levels at Everglades Depth

Estimation Network station P33, Everglades National Park, 1948-2010, southern Florida....

Figure 19. Landsat Thematic Mapper satellite images showing study area in 2000 before the fires (upper left), in 2004 immediately following the fires (upper right), in 2011 providing evidence for lack of vegetation

recovery (lower left) 23

\section{Tables}

Table 1. Percentage of fire scar locations and (or) presence that were verified through visual inspection of Landsat satellite imagery by year, southern Florida, 1994-2004

Table 2. Sample of information on scar visibility and location determined from visual comparison of database fire polygons and Landsat satellite imagery, southern Florida

Table 3. Summary statistics for all fires documented by staff at Everglades National Park, southern Florida, 1948-2010.

Table 4. Summary statistics for fires, by type, recorded by staff at Everglades National Park, southern Florida, 1948-2010.

Table 5. Summary statistics for fires, by type, recorded by staff at Big Cypress National Preserve, southern Florida, 1978-2010

Table 6. Summary statistics for fires, by type, for Big Cypress National Preserve, southern Florida, 1978-2010. 


\title{
Conversion Factors, Datums, and Abbreviations and Acronyms
}

\section{Conversion Factors}

Inch/Pound to SI

\begin{tabular}{lcl}
\hline & \multicolumn{1}{c}{ Bultiply } & \multicolumn{1}{c}{ To obtain } \\
\hline acre & Area & \\
acre & 4,047 & square meter $\left(\mathrm{m}^{2}\right)$ \\
\hline
\end{tabular}

SI to Inch/Pound

\begin{tabular}{llll}
\hline & Multiply & By & To obtain \\
\hline & Length & \\
\hline meter $(\mathrm{m})$ & 3.281 & foot $(\mathrm{ft})$ & \\
$\operatorname{meter}(\mathrm{m})$ & 1.094 & yard $(\mathrm{yd})$ & \\
kilometer $(\mathrm{km})$ & 0.6214 & mile $(\mathrm{mi})$ & \\
\hline
\end{tabular}

\section{Datums}

Vertical coordinate information is referenced to the North American Vertical Datum of 1988 (NAVD 88). Horizontal coordinate information is referenced to the insert North American Datum of 1983 (NAD 83).

\author{
Abbreviations and Acronyms \\ BICY Big Cypress National Preserve \\ DI Department of the Interior \\ EVER Everglades National Park \\ GPS Global Positioning System \\ NINO-3 El-Nino-3 \\ NPS National Park Service \\ quad quadrangle (U.S. Geological Survey 7.5-minute topographic map) \\ SOI Southern Oscillation Index \\ RAWS Remote Automated Weather Stations \\ $R^{2} \quad$ coefficient of determination \\ USGS U. S. Geological Survey \\ WFR Wildland Fire Report
}





\title{
Fire History of Everglades National Park and Big Cypress National Preserve, Southern Florida
}

\author{
By Thomas J. Smith III, Ann M. Foster, and John W. Jones
}

\section{Introduction}

Fire occurs naturally in the environment on most continents, including Africa (Ryan and Williams, 2011), Asia (Kauhanen, 2008), Australia (Kutt and Woinarski, 2007), Europe (Eshel and others, 2000), South America (Fidelis and others, 2010), and North America (Van Auken, 2000). Antarctica appears to be the only continent that has no reported natural fires, although fire is common in grasslands of Patagonia and on islands in the Subantarctic region (Gonzalez and others, 2005; McGlone and others, 2007).

Natural fires also have occurred over thousands of years, and the frequencies of these natural fires have changed (Power and others, 2008). This has resulted in altered ecosystems at landscape scales. Recent evidence suggests that the treeless desert pastures of Tibet once were forests and woodlands, and charcoal deposits indicate that fire was more frequent in the past (Miehe and others, 2006). Human cultural development has been influenced by changes in natural fire frequencies. Zong and others (2007) reported that human suppression of fires in coastal areas of China allowed the development of rice paddy cultivation and, thus, increased the size of human populations.

In addition to its almost world-wide occurrence, fire plays a role in a wide variety of ecosystem types. Grassland, savanna, steppe, woodland, forest, and wetland ecosystems all have fire as part of their natural ecology (Veblen and Lorenz, 1988; Chokkalingam and others, 2007; Miller and others, 2009, Keith and others, 2010; Staver and others, 2011). Fires affect these ecosystems in various ways, the most obvious of which is the direct effect on plant biomass (for example, Van Wilgen, 1982; Mack and others, 2008). However, fire has many other effects on ecosystems. Plant species richness, diversity, and functional types can change in response to fire (Peterson and Reich, 2008). All properties of the surface soils (such as bulk density, particle size distribution, $\mathrm{pH}$, and organic carbon and nitrogen content) can be altered by the frequency and severity of fire (Boerner and others, 2009). Faunal communities will respond to fire, with some species increasing (Fuhlendorf and others, 2006) and other species decreasing, after the fire (Vasconcelos and others, 2009). The position of the ecotone between differing ecosystems also is influenced by fire occurrence (Heisler and others, 2003; Briggs and others, 2005; Smith and others, 2013). 
Fire has been used as a management tool in various ecosystems around the world. Prairies, grasslands, and savannas are fire-maintained ecosystems where fire is used to deter invasion by shrubs and trees (Grant and others, 2009; Scheintaub and others, 2009). Similarly, fire plays an important role in woodlands and forests by influencing species composition and succession such, as the use of fire in coniferous forests to prevent encroachment by hardwoods (Phillippe and others, 2011). Fire also has been used to manage wetland ecosystems for more than 50 years (Lynch, 1941; Frost, 1995). Uses have included returning marshes to early successional states, increasing forage for wildlife (Lynch, 1941). In all fire-influenced ecosystems, prescribed burns are routinely used to reduce fuel loads, reducing the possibility of catastrophic fires.

\section{Fire in Southern Florida and the Everglades}

Fire has always been an integral part of the ecosystems of southern Florida, especially in the Everglades (Robertson, 1962; Wade and others, 1980; Cohen, 1984) (fig. 1). Botanists and ornithologists who explored the area in the early 1900s commented on fires. Small (1916) reported what he considered to be catastrophic fires burning from Madiera Hammock all the way to Cape Sable, a distance almost 25 miles. He stated: “... we saw miles of hammock and rolling clouds of black smoke skyward. This calamity was not confined to the neighborhood of Madiera Bay but in the Cape Sable region three or four vast forest fires were seen." Following a subsequent trip to southwestern Florida near Everglades City Small (1923) reported: "The long drought had turned a large part of the vegetation into tinder, and prairies, pinelands, hammocks and cypress strands were food for terrific conflagrations." Holt and Sutton (1926) reported extensive fires burning in the Cape Sable marshes during their ornithological explorations of the winter of 1924. A fire is clearly visible burning in the Cape Sables marshes in a 1928 aerial photograph (fig. 2). Beard (1938) conducted wildlife surveys during the mid1930s in the region that would become Everglades National Park. He reported: "The Everglades park area was badly burned during the winter of 1937-8, and there was no time during the drier part of the year that one could not see smoke somewhere on the horizon." 


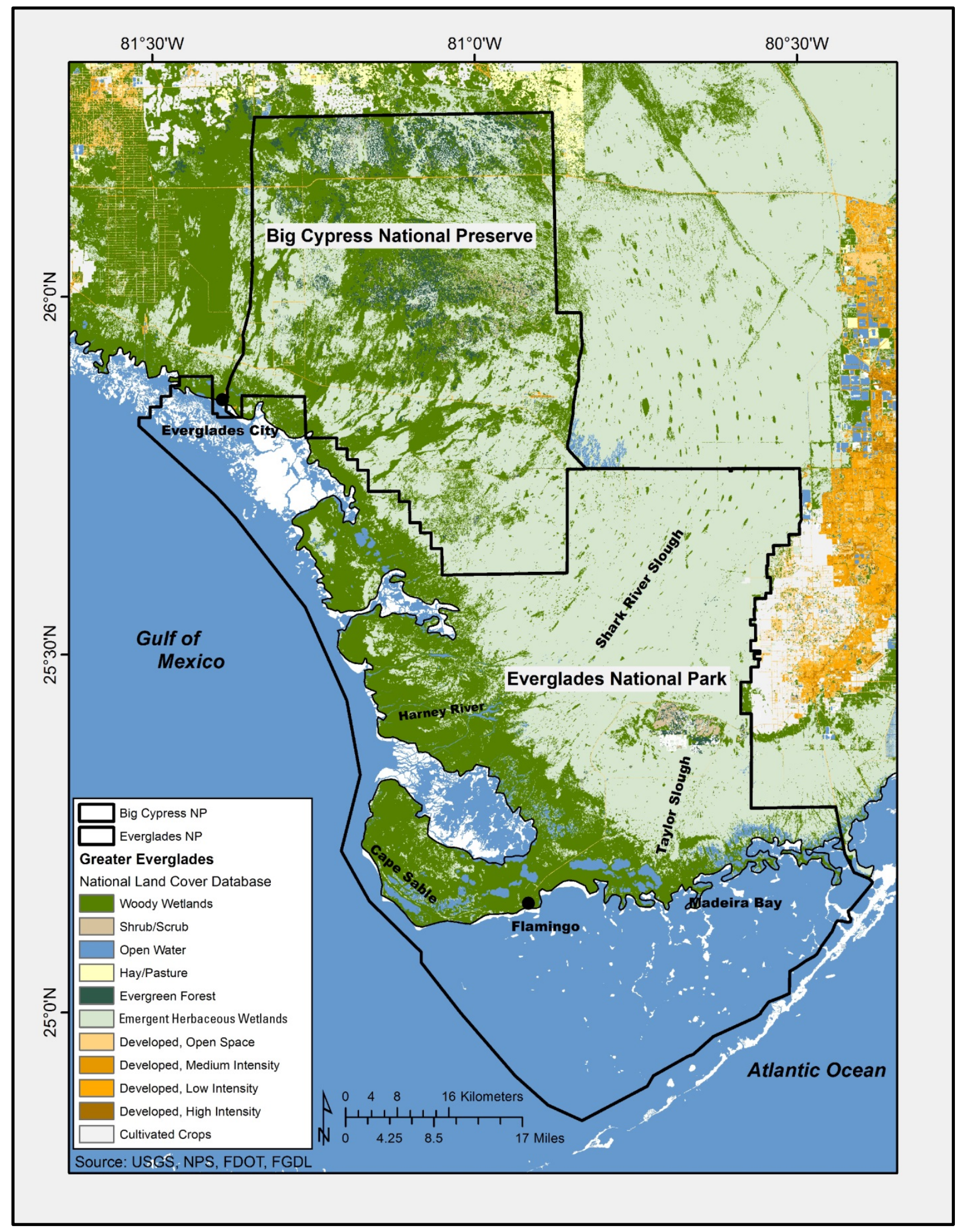

Figure 1. Map showing Everglades National Park and Big Cypress National Preserve, southern Florida. 


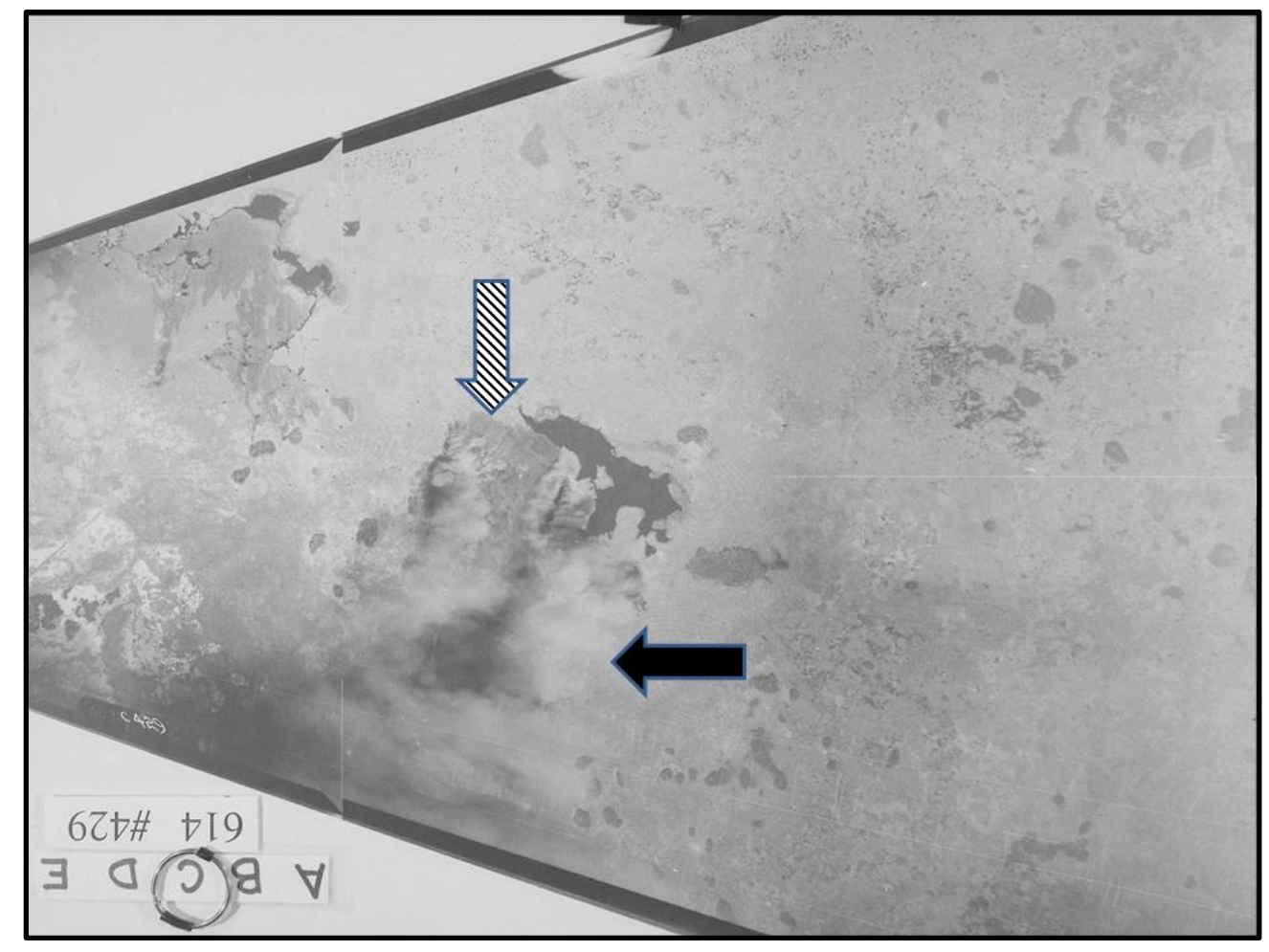

Figure 2. Aerial photograph showing fire burning on Cape Sable, southern Florida, 1928. Smoke is indicated by the solid black arrow and the fire boundary is indicated by the striped arrow. The photograph was taken March 29, 1928 by the U.S. Army Air Corps.

Early ecologists of the region thought that man, both aboriginal and immigrant, was the primary cause for fires in the Everglades (Small, 1924, 1930; Beard, 1938; Egler, 1952). Many of the fires reported from 1900 to 1945 were related to man, owing to the extensive drainage of the northern Everglades coupled with drought, especially in the 1930s (Beard, 1938; Phillips, 1940; Dovell, 1942). Robertson (1953), in the first review of fire in Everglades National Park, showed that lightning was a causative factor for many fires. He noted that, during 18 months in 1951-52, about 53 percent of all fires in Everglades National Park were caused by lightning. A 2007 study using the fire history database of Everglades National Park showed that lightning fires are a common occurrence in the park (Slocum and others, 2007).

\section{Fire Management in Everglades National Park and the Big Cypress National Preserve}

Over the past several decades, the staffs of Everglades National Park (EVER) and Big Cypress National Preserve (BICY) have acquired a substantial amount of wildfire history data in the form of paper records and tabular data (Klukas, 1973; Bancroft, 1976; Taylor 1980, 1981). Over the years, multiple methods were used to delineate fire perimeters: (1) hand drawn on U.S. Department of the Interior fire reporting forms, (2) hand drawn on 1:24,000 scale U.S. Geological Survey (USGS) topographic quadrangle (quad) sheets, (3) demarcated using Global Positioning System (GPS) technology (DeVries and others, 1992), or (4) digitized from remotely sensed images (fig. 3). The 
significant role of wildfire on the landscape makes the availability of these data in a readily usable format vital for many park planning and operational functions, including ongoing fire management activities and fire ecology studies, as well as for addressing various resource management issues related to the Comprehensive Everglades Restoration Plan. In this report, we document how these data have been incorporated in a user friendly spatial database and present an initial analysis of fire in EVER and BICY.
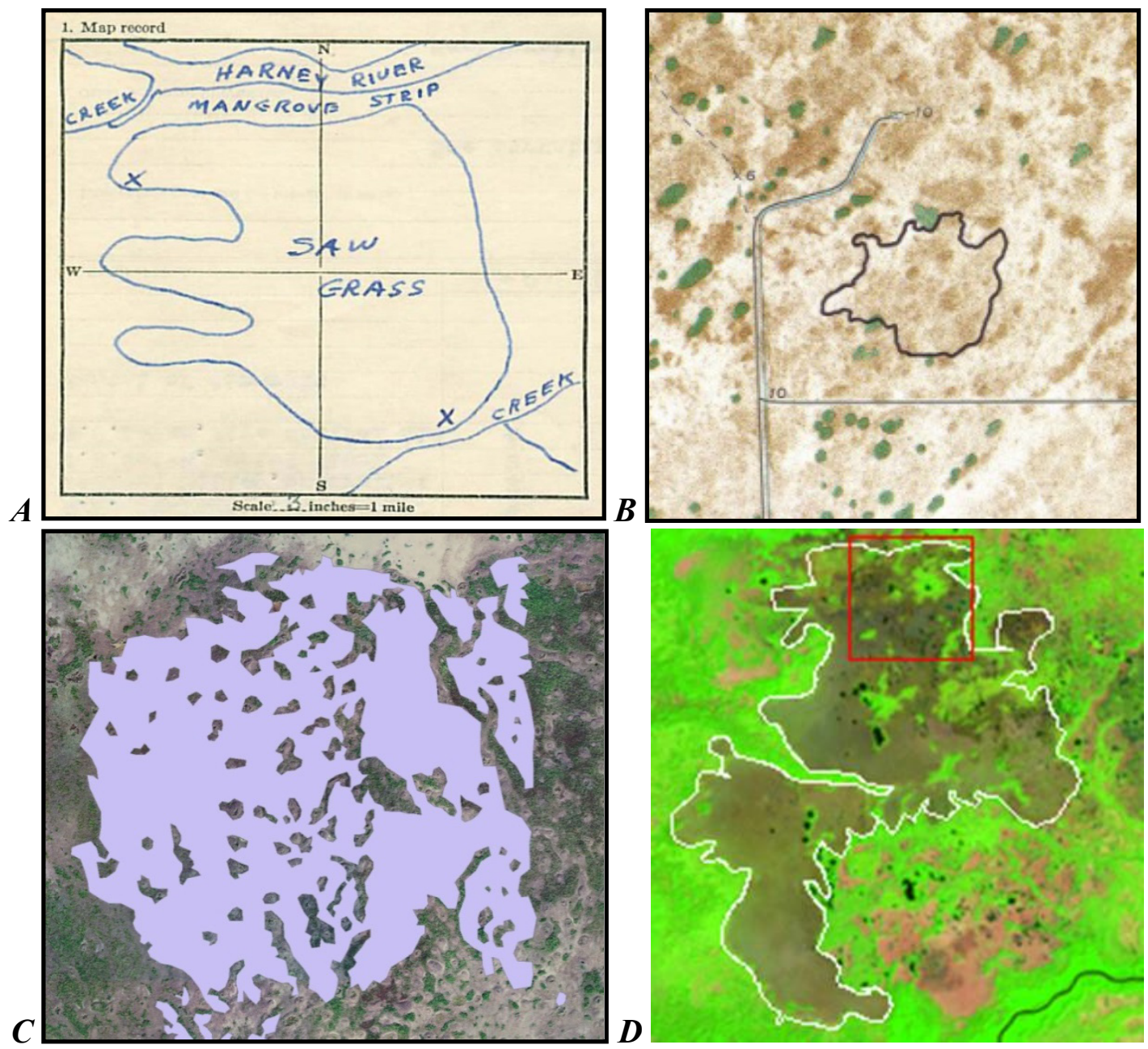

Figure 3. Examples of methods used to delineate fire perimeters; $(A)$ hand drawn on U.S. Department of the Interior fire reporting form (X's represent the fire ignition points), $(B)$ hand drawn on quadrangle (U.S. Geological Survey 7.5-minute topographic map), (C) controlled burn mapped in great detail by fire management staff at BICY using Global Positioning System, and $(D)$ digitized from a remotely sensed image. 


\section{Methods}

\section{Geodatabase Development}

The fire history geodatabases are a collection of data detailing the location and attributes of fires that have occurred in Everglades National Park and Big Cypress National Preserve. These databases were created using 1948-2010 fire records for EVER and 1978-2010 fire records for BICY. The geodatabases originally were created in 2003. Attributes for the geodatabases were based on the Proposed National Park Service Fire GIS Data Standards (April 2003), as provided by the Southeast Regional Fire GIS Specialist and predate the National Wildfire Coordinating Group data standards. Subsequent updates by both the USGS and the National Park Service (NPS) maintained this format. As identified by Everglades National Park fire specialists, 19 additional attributes were added to the standards. These attributes are account number, fire cost, coordinates, 9 weather attributes, fire danger rating, staffing class, 3 fire behavior attributes, and the water level at the Everglades Depth Estimation Network station NP 44 for all years. These attributes were not available for many fires, especially those fires that occurred early in the history of Everglades National Park and Big Cypress National Preserve.

Hard copies of paper fire records recorded on DI-1201, DI-1202, and Wildland Fire Report (WFR) Forms were obtained from EVER and BICY, and taken to the Gainesville, Florida, laboratory. Information was interpreted from the forms to assign the attributes associated with the fires in the geodatabases. The interpretation process was systematized by first examining the DI-1201/2/WFR form and assigning a corresponding field in the database to the fields in the form. Where none to one correspondence existed, or it was not possible to interpret the attribute data in the DI-1201/2/WFR form due to lack of an instructional manual, those data were not included in the geodatabase. The design of the form changed over time, and access to the form instructions for earlier versions was not available. Therefore, the consistency of the data changed as the ability to interpret the forms changed with the versions of the forms. Weather data that were not included in the fire reports were obtained from the Western Regional Climate Center Remote Automated Weather Stations (RAWS) USA Climate Archive (http://www.raws.dri.edu/index.html).

Spatial data about the fires were derived from various sources, including hand-drawn maps in the paper fire records, hand-drawn mylar maps, and digital-data layers. The databases were organized into ESRI ArcGIS ${ }^{\mathrm{TM}}$ feature datasets. Each feature dataset includes a polygon feature class that includes a comprehensive table of spatial records extracted from the fire records and a point feature class that includes records of fire ignition or fire centroid points. In cases where no map existed, coordinate information was used in the fire reports to create a spatial record according to a strict set of criteria. This was often true for the numerous small fires (for example, $<1.0$ acre) in the databases.

The databases were checked to ensure that all fires had both a point and a perimeter. The points were used to determine whether the fire was classified as "inside" or "outside" of EVER or BICY boundaries. It was not unusual for a part of an "inside" fire to burn outside of EVER or BICY. Conversely, an "outside" fire may have crossed a boundary and burned areas inside the park or preserve perimeter. Boundaries also changed as additional land was acquired. The classification of inside or outside the park was based on the location of a boundary at the time of the fire. 
Fire perimeter polygons were constructed using the maps associated with the fire reporting forms. In some cases, digital perimeters were available. When digital perimeters were available, they were compared to the paper maps associated with the fire reporting forms and checked for accuracy. Where conflicts in information were apparent, the map in the fire report was assumed to be the most correct information source and the final information was taken from the map. In some cases, the perimeter shape was correct but spatially displaced. This was most apparent when the fire occurred along man-made features in the landscape such as roads or trails. In these cases, the placement of the polygons was changed and noted in the comments field of the geodatabase. The total area burned for each fire then was calculated using ArcGIS ${ }^{\mathrm{TM}}$.

When a fire did not have a map demarcating a perimeter, standard shapes were used as proxies for the fire perimeters. Circles were used when the burned acreage estimate from the fire reporting form was less than 1.0 acre in size. Rectangles were used for estimated burned acreages larger than 1.0 acre and were sized to equal the acreage reported (fig. 4). These circle and rectangle fire "perimeters" were positioned geographically based on information obtained from the fire narrative.

All fires were categorized into three types: Natural, Prescribed, and Suppressed. Natural fires were those started by natural means, in most cases by lightning strikes. Prescribed fires were those set by a park fire team for environmental management purposes. A second purpose of prescribed fires is to reduce hazardous fuels to provide increased protection for the wildland-urban interface. Suppressed fires were those caused by humans that were not for management purposes and were either accidental (for example, an escaped campfire) or intentional (that is, arson) in nature. A fourth fire type was encountered occasionally in the database. These were reported as "prescribed natural" or "natural prescribed" in the fire narratives. In all cases, these were naturally caused fires that were determined to be no threat to life or property when discovered, so they were allowed to burn out with no suppression activity. These fires were classed as "natural" in the database.

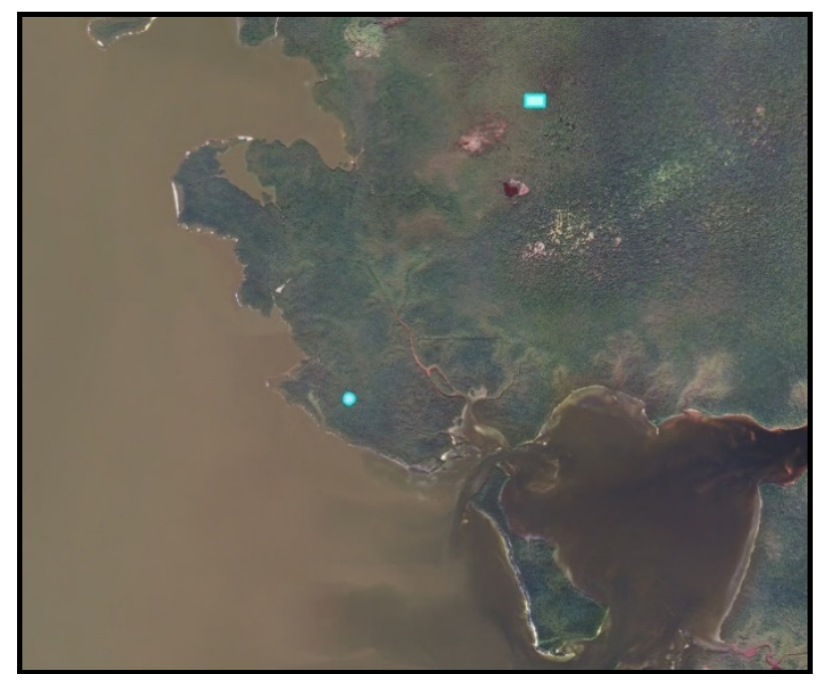

Figure 4. Examples of fires represented as rectangles or circles, north of Lostmans Key, southern Florida. The rectangle is the 3-acre Wood Key Cove fire (number 59008). The circle is the Jimmie's Hammock fire (number 54002). The background image is a true color DOQQ from 2006. 
Fire perimeters from 1994-2004 were visually compared against Landsat archive satellite imagery as part of research on the use of satellite data to map Everglades fire history. Cloud-free satellite images following the occurrence of each fire were inspected, noting fire scars large enough to be visible in Landsat imagery (that is, 3 or more acres in size) that were in the wrong location. Only a small percentage of polygons were misplaced, verifying that the reporting-form polygons were accurate (table 1). The placement of the polygons then was corrected in the geodatabase. Fires for which no scar was apparent in the imagery also were documented (table 2). All locational errors were noted in the database.

Table 1. Percentage of fire scar locations and (or) presence that were verified through visual inspection of Landsat satellite imagery by year, southern Florida, 1994-2004.

\begin{tabular}{|c|c|}
\hline Year & $\begin{array}{c}\text { Percentage of } \\
\text { verified polygons }\end{array}$ \\
\hline 1994 & 86 \\
\hline 1995 & 91 \\
\hline 1996 & 93 \\
\hline 1997 & 91 \\
\hline 1998 & 100 \\
\hline 1999 & 95 \\
\hline 2000 & 94 \\
\hline 2001 & 93 \\
\hline 2002 & 96 \\
\hline 2003 & 98 \\
\hline 2004 & 98 \\
\hline
\end{tabular}

Table 2. Sample of information on scar visibility and location determined from visual comparison of database fire polygons and Landsat satellite imagery, southern Florida.

\begin{tabular}{|c|c|c|c|c|}
\hline Fire date & $\begin{array}{l}\text { Wrong } \\
\text { location }\end{array}$ & No scar visible & Image date & Acres \\
\hline 1994_10_11 & NA & $\mathrm{X}$ & 1994_11_11_TM5 & 1,960 \\
\hline 1994_07_05 & NA & $\mathrm{X}$ & 1994_11_11_TM5 & 1,000 \\
\hline 1994_07_06 & NA & NA & 1994_11_11_TM5 & 3,500 \\
\hline 1995_07_08 & $\mathrm{X}$ & NA & 1996_02_18_TM5 & 387 \\
\hline 1996_07_31 & NA & $\mathrm{X}$ & 1997_01_03_TM5 & 53 \\
\hline 1996_08_23 & $\mathrm{X}$ & NA & 1997_01_03_TM5 & 878 \\
\hline
\end{tabular}




\section{Data Summary}

The total number of fires for EVER and BICY were calculated for each year for all inside and outside fires by type. Total area burned was calculated from the GIS polygon data for the same categories.

\section{Fires, Climate, and Water-Level Data}

Previous research has indicated that both number of fires and area burned for natural and suppressed fires were related to climate signals such as the El-Nino-Southern Oscillation (ENSO; Beckage and others, 2003; Beckage and Platt, 2003). Numerous other climate teleconnection indices also have been developed, including the Southern Oscillation Index (SOI; Troup, 1965; Trenberth, 1984), the Atlantic Multidecadal Oscillation (AMO; Schlesinger and Ramankutty, 1994), the North Atlantic Oscillation (NAO; Barnston and Livezey, 1987), El-Nino-3 (NINO-3; Trenberth, 1997), and the Pacific Decadal Oscillation (PDO; Mantua and others, 1997). Monthly data for these indices were obtained from the "Climate Indices" Web site of the National Oceanic and Atmospheric Administration Earth System Research Laboratory (http://www.esrl.noaa.gov/psd/data/climateindices/). Water-level data for the Everglades Depth Estimation Network station P33 (hereafter referred to as "P33") were obtained from Everglades National Park. The P33 water-level data were detrended because they show a steady rise in water levels over time, as is seen for many Everglades National Park stations (Karamperidou and others, 2013). Yearly values for, number of fires and area burned (for natural and suppressed inside fires only), climate indices, and P33 water levels were calculated for "water years" (October 1 through September 30). Additionally, for the climate indices and P33 water levels, mean values were calculated for the March-June period of each year, following Beckage and Platt (2003) and Beckage and others (2003). This period is the end of the dry season, so vegetation is particularly susceptible to catching fire.

The number of fires and the area burned for Natural and Natural plus Suppressed fires were related to the climate indices and P33 water levels using simple linear regression. Prescribed fires are for direct management action and are not related to climate variables. These analyses were done for EVER only because most BICY fires are prescribed and are not related to climate. 


\section{Results and Discussion}

\section{Overall Patterns and Occurrence of Fire}

\section{Everglades National Park}

From 1948 to 2010, a total of 2,588 fires were reported in EVER. Of this total, 1,784 fires were Inside, with 533 fires classified as Suppressed, 513 fires classified as Natural, and 738 fires classified as Prescribed. A total of 804 Outside fires were reported for EVER over this time period. For Outside fires, 701 fires were classified as Suppressed, 89 fires were classified as Natural, and 14 fires were classified as Prescribed. The numbers and types of Inside (fig. 5) and Outside (fig. 6) fires also varied greatly between years. These data are summarized in table3.

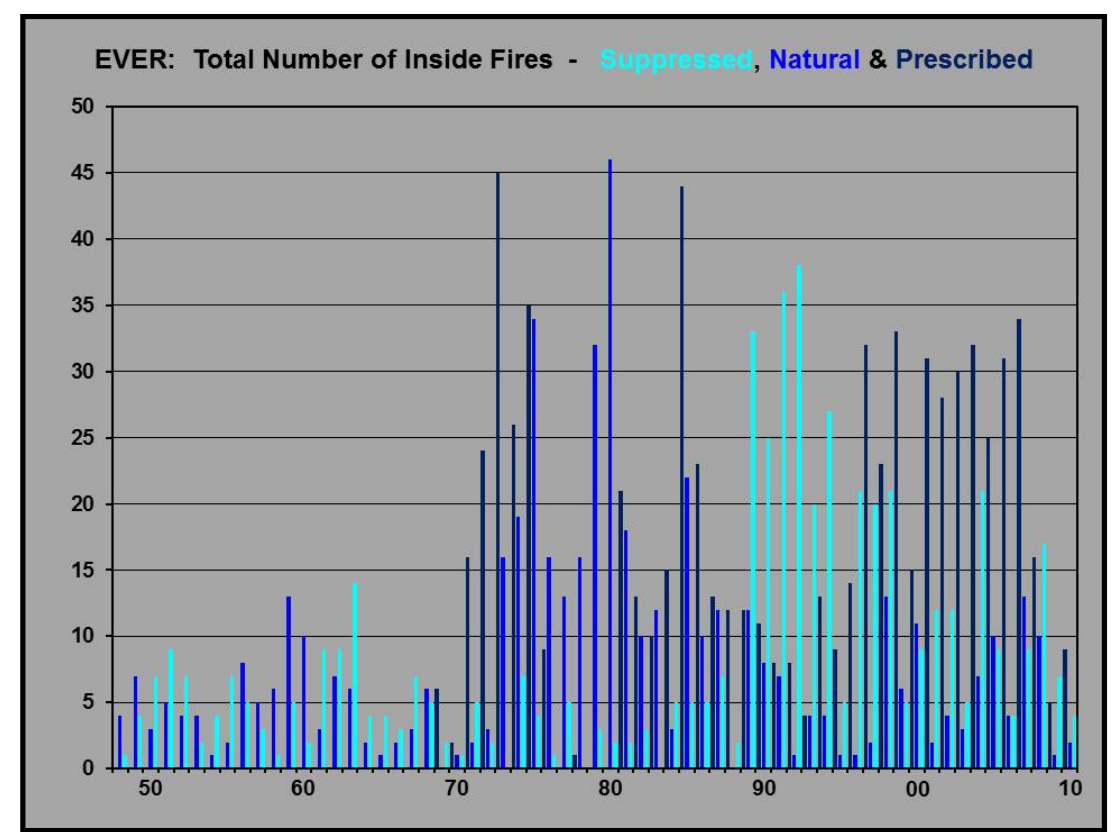

Figure 5. Graph showing yearly time series for numbers of "Inside" Suppressed, Natural, and Prescribed fires for Everglades National Park, southern Florida, 1948-2010. 


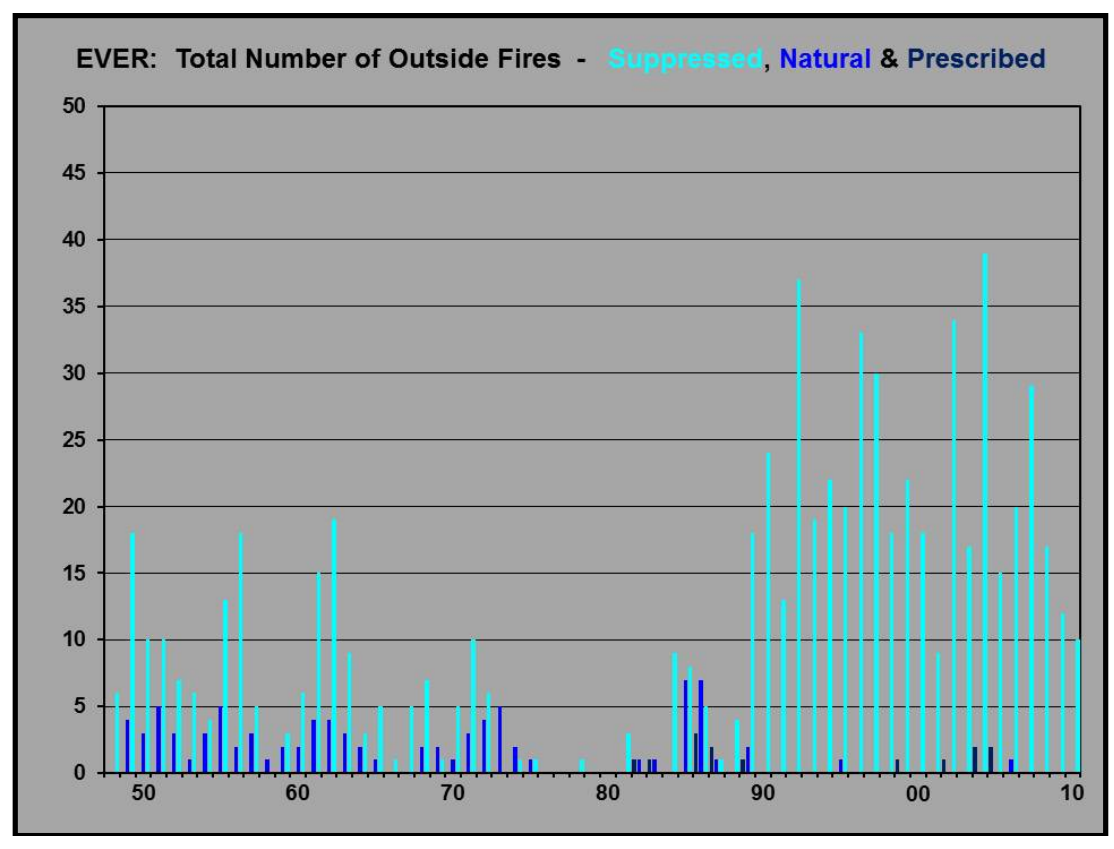

Figure 6. Graph showing yearly time series for numbers of "Outside" Suppressed, Natural, and Prescribed fires for Everglades National Park, southern Florida, 1948-2010.

Table 3. Summary statistics for all fires documented by staff at Everglades National Park, southern Florida, 19482010. Statistics are defined as follows, SUM is the summation over all years in the database for that grouping (for example, Total, Inside, Number). MIN and MAX are the minimum and maximum for a grouping. AVE is the average for a grouping. STDEV, SKEW and KURT are the standard eviation, skewness, and kurtosis for the groupings.

\begin{tabular}{|l|r|r|r|r|r|r|}
\hline \multirow{3}{*}{ Statistic } & \multicolumn{5}{|c|}{ Total } \\
\cline { 2 - 7 } & \multicolumn{2}{|c|}{ Inside } & \multicolumn{2}{c|}{ Outside } & \multicolumn{2}{c|}{ Combined } \\
\cline { 2 - 7 } & Number & \multicolumn{1}{|c|}{ Acres } & Number & Acres & Number & Acres \\
\hline SUM & 1,784 & $1,032,802$ & 804 & 775,643 & 2,588 & $1,808,445$ \\
\hline MIN & 0 & 0 & 0 & 0 & 0 & 0 \\
\hline MAX & 73 & 110,772 & 41 & 192,073 & 73 & 192,073 \\
\hline AVE & 28.3 & 16,393 & 12.8 & 12,312 & 20.5 & 14,352 \\
\hline STDEV & 19.7 & 20,666 & 10.0 & 29,994 & 17.1 & 25,735 \\
\hline SKEW & 0.5 & 2.5 & 0.8 & 4.2 & 1.0 & 3.8 \\
\hline KURT & -0.9 & 7.5 & 0.2 & 21.4 & 0.3 & 19.6 \\
\hline
\end{tabular}

A total of 1,808,445 acres have burned in EVER over the period of record, with many areas (for example the pinelands) burning multiple times. Of this acreage, 1,032,802 acres were Inside, with 493,340 acres classified as Suppressed, 103,307 acres classified as Natural, and 436,156 acres classified as Prescribed. For fires classified as Outside, the total was 775,643 acres burned, with 649,701 acres classified as Suppressed, 108,956 acres classified as Natural, and 16,986 acres classified as Prescribed. 
As with total numbers of fires, there was great year-to-year variation in acres burned (figs. 7 and 8 ). These data are summarized in table 4.

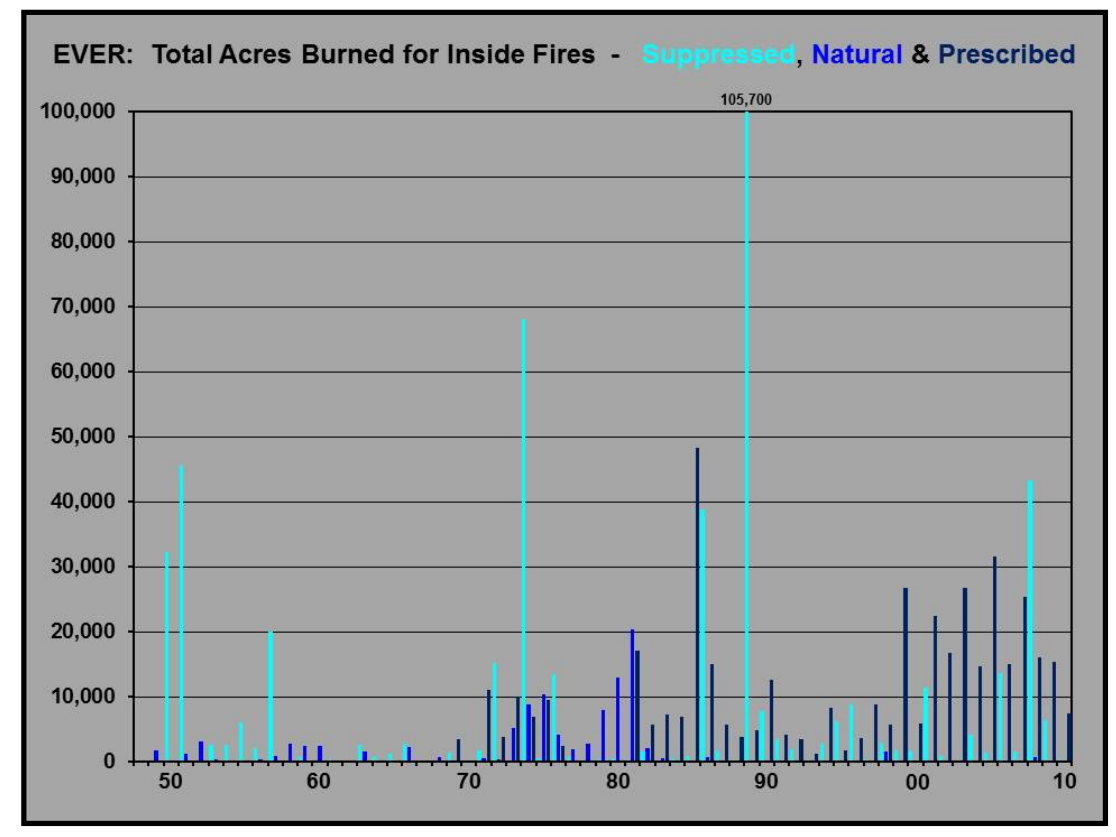

Figure 7. Graph showing yearly time series of acres burned for "Inside" Suppressed, Natural, and Prescribed fires for Everglades National Park, southern Florida, 1948-2010.

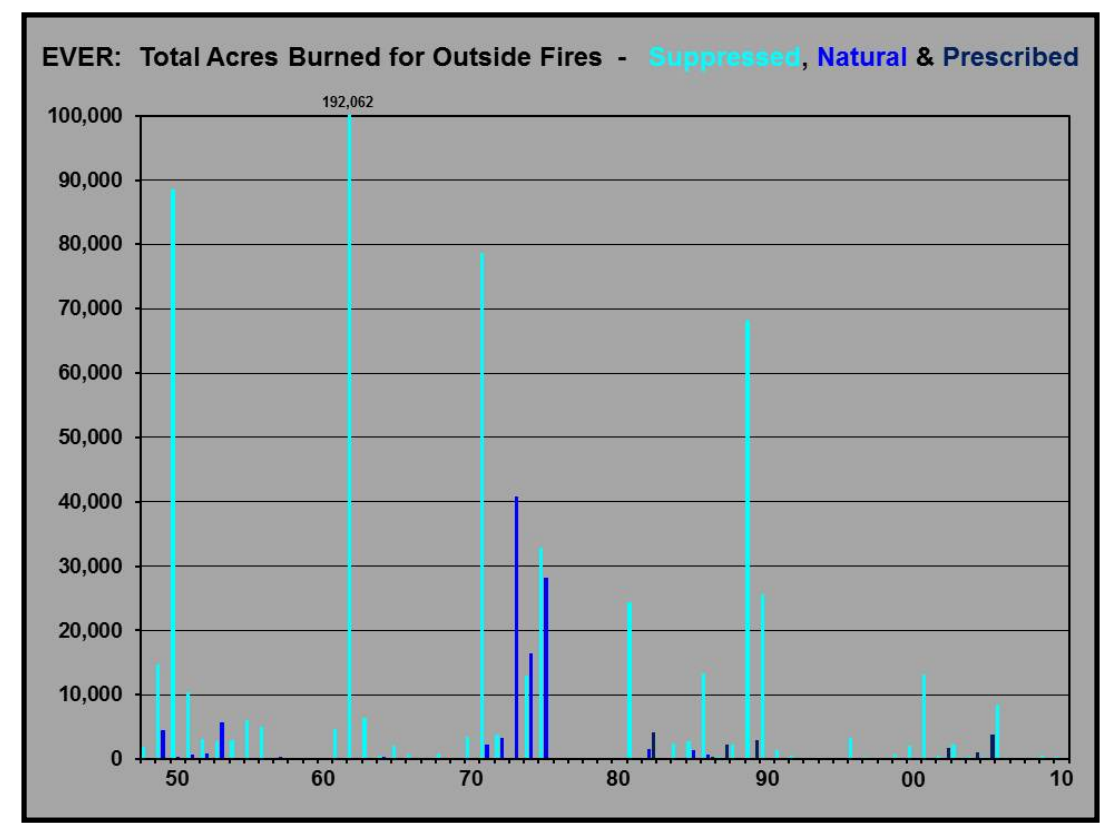

Figure 8. Graph showing yearly time series of acres burned for "Outside" Suppressed, Natural, and Prescribed fires for Everglades National Park, southern Florida, 1948-2010. 
Table 4. Summary statistics for fires, by type, recorded by staff at Everglades National Park, southern Florida, 1948-2010.

\begin{tabular}{|c|c|c|c|c|c|c|}
\hline \multirow{2}{*}{ Statistic } & \multicolumn{2}{|c|}{ Inside } & \multicolumn{2}{|c|}{ Outside } & \multicolumn{2}{|c|}{ Total } \\
\hline & Number & Acres & Number & Acres & Number & Acres \\
\hline \multicolumn{7}{|c|}{ Suppressed } \\
\hline SUM & 533 & 493,340 & 701 & 649,701 & 1,234 & $1,143,040$ \\
\hline MIN & 0 & 0 & 0 & 0 & 0 & 0 \\
\hline MAX & 38 & 105,700 & 39 & 192,063 & 39 & 192,063 \\
\hline AVE & 8.5 & 7,831 & 11.1 & 10,313 & 9.8 & 9,072 \\
\hline STDEV & 8.8 & 17,948 & 10.2 & 29,060 & 9.6 & 24,087 \\
\hline SKEW & 1.8 & 3.7 & 1.0 & 4.7 & 1.3 & 4.9 \\
\hline KURT & 2.8 & 15.7 & 0.3 & 25.8 & 1.1 & 29.4 \\
\hline \multicolumn{7}{|c|}{ Natural } \\
\hline SUM & 513 & 103,307 & 89 & 108,956 & 602 & 212,264 \\
\hline MIN & 0 & 0 & 0 & 0 & 0 & 0 \\
\hline MAX & 46 & 20,431 & 7 & 40,797 & 46 & 40,797 \\
\hline AVE & 8.1 & 1,640 & 1.4 & 1,729 & 4.8 & 1,685 \\
\hline STDEV & 8.5 & 3,534 & 1.8 & 6,506 & 7.0 & 5,215 \\
\hline SKEW & 2.3 & 3.5 & 1.4 & 4.9 & 3.1 & 5.2 \\
\hline KURT & 6.8 & 14.2 & 1.3 & 25.4 & 12.3 & 31.4 \\
\hline \multicolumn{7}{|c|}{ Prescribed } \\
\hline SUM & 738 & 436,156 & 14 & 16,986 & 752 & 453,141 \\
\hline MIN & 0 & 0 & 0 & 0 & 0 & 0 \\
\hline MAX & 45 & 48,287 & 3 & 4,170 & 45 & 48,287 \\
\hline AVE & 11.7 & 6,923 & 0.2 & 270 & 6.0 & 3,563 \\
\hline STDEV & 13.9 & 9,596 & 0.6 & 864 & 10.8 & 7,563 \\
\hline SKEW & 0.9 & 2.0 & 3.0 & 3.5 & 1.9 & 3.1 \\
\hline KURT & -0.3 & 5.0 & 8.8 & 11.7 & 2.8 & 11.6 \\
\hline
\end{tabular}




\section{Big Cypress National Preserve}

Although the BICY fire program began in 1978, 30 years after the program in EVER started, BICY has had more fires than EVER. During 1978-2010, a total of 2,642 fires were reported for BICY. Of this total, 2,366 fires were Inside, with 1,257 fires classified as Suppressed, 523 fires classified as Natural, and 586 fires classified as Prescribed. A total of 276 Outside fires were reported for BICY over this time period. For Outside fires, 200 fires were classified as Suppressed, 66 fires were classified as Natural, and 10 fires were classified as Prescribed. As with EVER, the numbers and types of Inside (fig. 9) and Outside (fig. 10) fires varied greatly between years. These data are summarized in table 5.

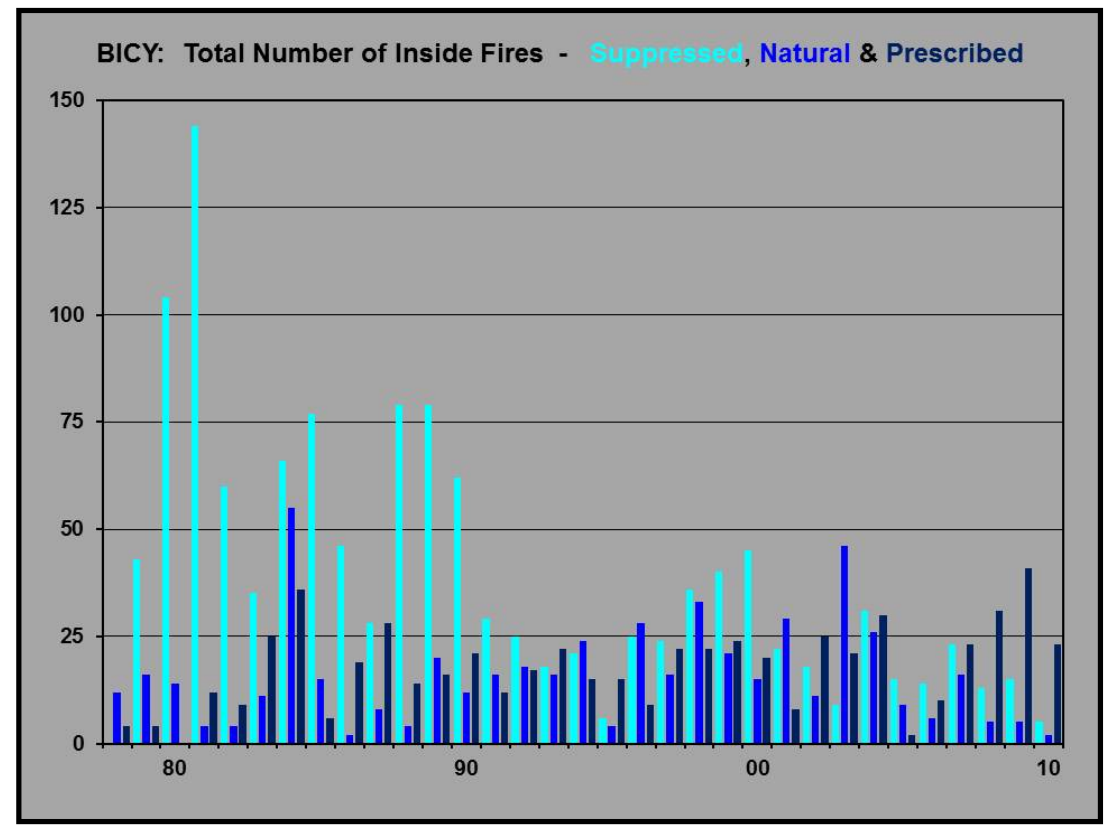

Figure 9. Graph showing yearly time series of total fires for "Inside" Suppressed, Natural, and Prescribed fires for Big Cypress National Preserve, southern Florida, 1978-2010. 


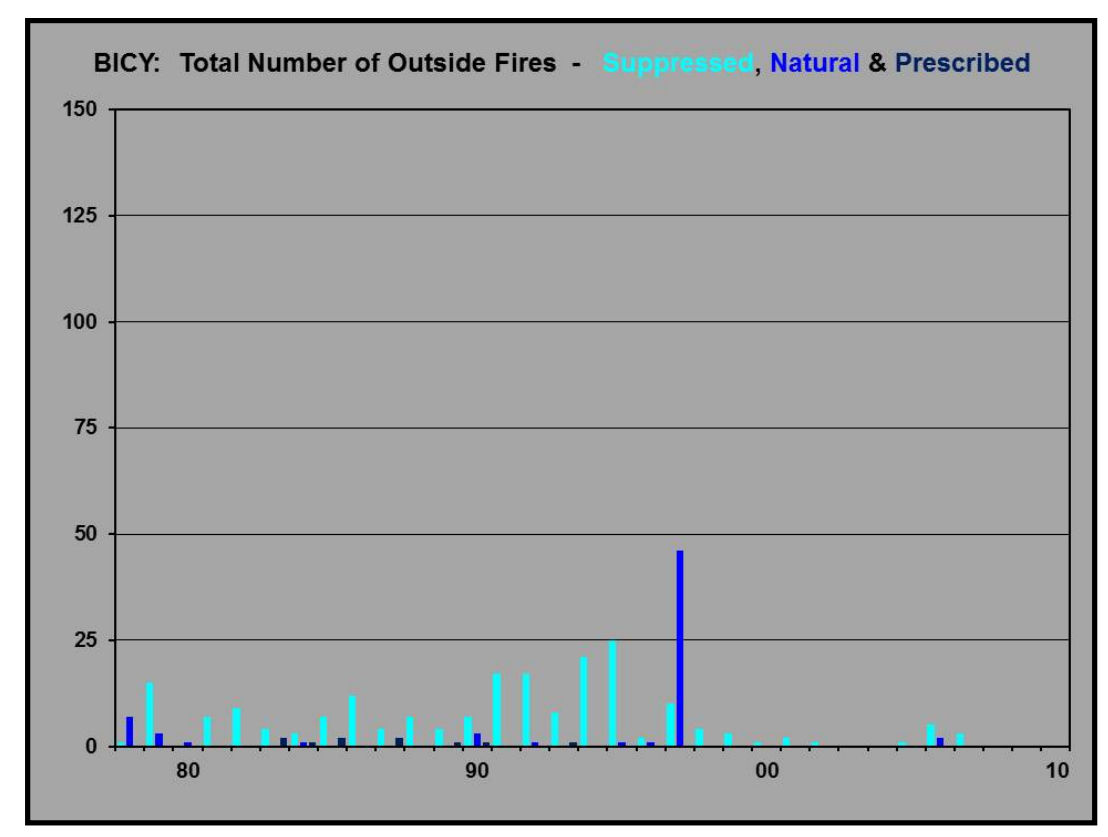

Figure 10. Graph showing yearly time series of total fires for "Outside" Suppressed, Natural, and Prescribed fires for Big Cypress National Preserve, southern Florida, 1978-2010.

Table 5. Summary statistics for fires, by type, recorded by staff at Big Cypress National Preserve, southern Florida, 1978-2010.

\begin{tabular}{|l|r|r|r|r|r|r|}
\hline \multirow{3}{*}{ Statistic } & \multicolumn{6}{|c|}{ Totals } \\
\cline { 2 - 8 } & \multicolumn{2}{|c|}{ Inside } & \multicolumn{2}{c|}{ Outside } & \multicolumn{2}{c|}{ Combined } \\
\cline { 2 - 7 } & Number & Acres & Number & Acres & Number & \multicolumn{1}{c|}{ Acres } \\
\hline SUM & 2,366 & $1,411,899$ & 276 & 194,473 & 2,642 & $1,606,373$ \\
\hline MIN & 0 & 0 & 0 & 0 & 0 & 0 \\
\hline MAX & 144 & 83,017 & 46 & 163,552 & 144 & 163,552 \\
\hline AVE & 23.9 & 14,261 & 2.8 & 1,964 & 13.3 & 8,113 \\
\hline STDEV & 22.4 & 20,330 & 6.4 & 16,465 & 19.6 & 19,454 \\
\hline SKEW & 2.6 & 1.5 & 4.2 & 9.8 & 3.0 & 4.0 \\
\hline KURT & 9.3 & 1.5 & 22.4 & 97.6 & 12.8 & 22.4 \\
\hline
\end{tabular}

A total of 1,606,373 acres have burned in BICY during the period of record. As with EVER, many areas have burned multiple times. Of the total burned acreage, 1,411,899 acres were Inside, with 371,411 acres classified as Suppressed, 11,109 acres classified as Natural, and 1,029,369 acres classified as Prescribed. For fires classified as Outside, the total was 194,473 acres burned, with 190,939 acres classified Suppressed, 975 acres classified as Natural, and 2,560 acres classified as Prescribed. As with total numbers of fires, there was much year-to-year variation in acres burned (figs. 11 and 12). These data are summarized in table 6 . 


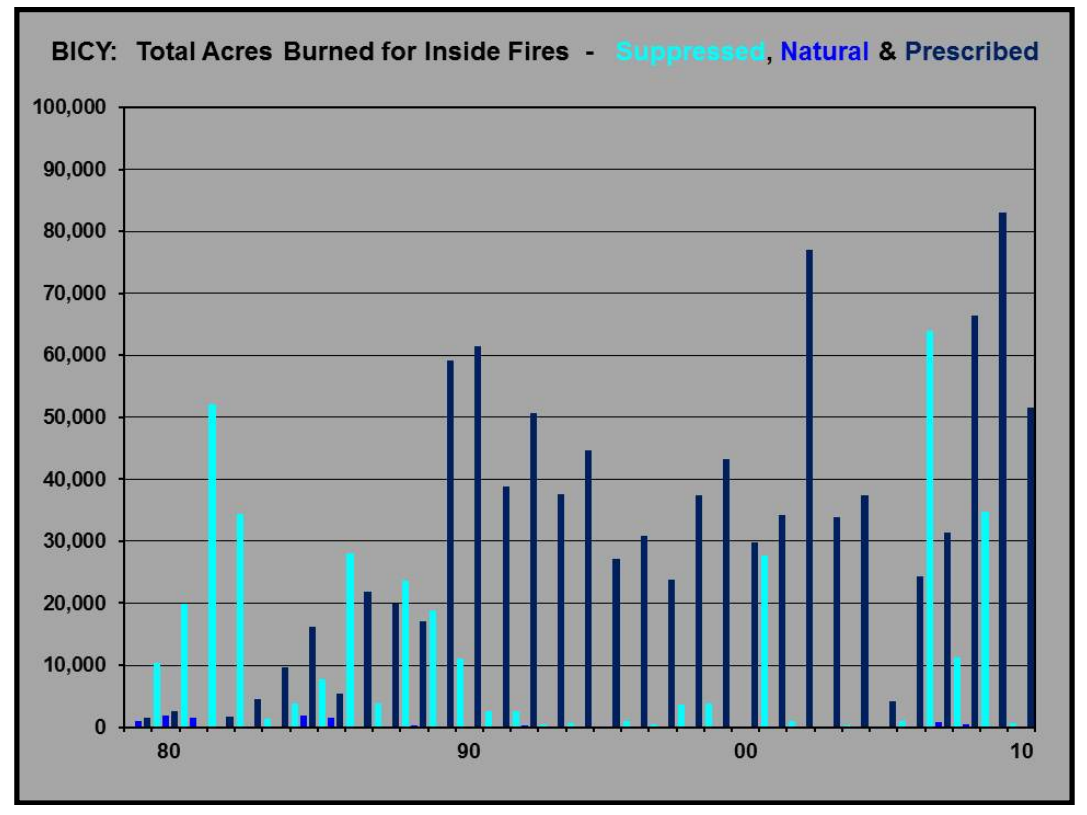

Figure 11. Graph showing yearly time series of acres burned for "Inside" Suppressed, Natural, and Prescribed fires for Big Cypress National Preserve, southern Florida, 1978-2010.

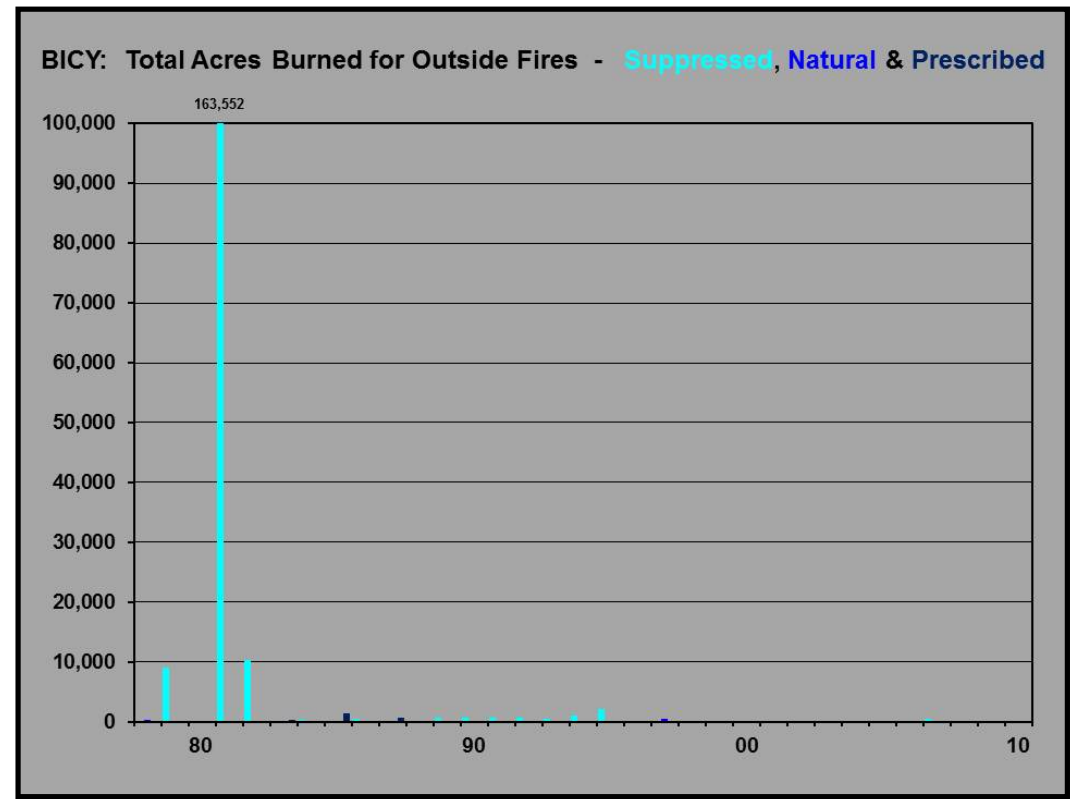

Figure 12. Graph showing yearly time series of acres burned for "Outside" Suppressed, Natural, and Prescribed fires for Big Cypress National Preserve, southern Florida, 1978-2010. 
Table 6. Summary statistics for fires, by type, for Big Cypress National Preserve, southern Florida, 1978-2010.

\begin{tabular}{|c|c|c|c|c|c|c|}
\hline \multirow{2}{*}{ Statistic } & \multicolumn{2}{|c|}{ Inside } & \multicolumn{2}{|c|}{ Outside } & \multicolumn{2}{|c|}{ Total } \\
\hline & Number & Acres & Number & Acres & Number & Acres \\
\hline \multicolumn{7}{|c|}{ Suppressed } \\
\hline SUM & 1,257 & 371,421 & 200 & 190,939 & 1,457 & 562,360 \\
\hline MIN & 0 & 0 & 0 & 0 & 0 & 0 \\
\hline MAX & 144 & 64,020 & 25 & 163,552 & 144 & 163,552 \\
\hline AVE & 38.1 & 1,1255 & 6.1 & 5,786 & 22.1 & 8,521 \\
\hline STDEV & 31.4 & 16,206 & 6.5 & 228,417 & 27.7 & 23,118 \\
\hline SKEW & 1.6 & 1.8 & 1.4 & 5.7 & 2.2 & 5.2 \\
\hline KURT & 3.0 & 3.0 & 1.4 & 32.5 & 5.8 & 31.8 \\
\hline \multicolumn{7}{|c|}{ Natural } \\
\hline SUM & 523 & 11,109 & 66 & 975 & 589 & 12,084 \\
\hline MIN & 2 & 7 & 0 & 0 & 0 & 0 \\
\hline MAX & 55 & 1,931 & 46 & 382 & 64 & 1,931 \\
\hline AVE & 15.8 & 337 & 2.0 & 29.5 & 8.9 & 183.1 \\
\hline STDEV & 12.2 & 554.9 & 8.0 & 87.1 & 12.4 & 423.4 \\
\hline SKEW & 1.5 & 2.1 & 5.5 & 3.1 & 1.9 & 3.1 \\
\hline KURT & 2.8 & 3.0 & 30.8 & 9.6 & 3.5 & 9.3 \\
\hline \multicolumn{7}{|c|}{ Prescribed } \\
\hline SUM & 586 & $1,029,369$ & 10 & 2,560 & 596 & $1,031,929$ \\
\hline MIN & 0 & 0 & 0 & 0 & 0 & 0 \\
\hline MAX & 41 & 83,017 & 2 & 1,427 & 41 & 83,017 \\
\hline AVE & 17.8 & 31,193 & 0.3 & 77.6 & 9.0 & 15,635 \\
\hline STDEV & 9.8 & 22,315 & 0.6 & 264.5 & 11.2 & 22,157 \\
\hline SKEW & 0.2 & 0.5 & 2.0 & 4.6 & 1.0 & 1.3 \\
\hline KURT & -0.2 & -0.3 & 2.7 & 22.7 & -0.2 & 0.9 \\
\hline
\end{tabular}




\section{Comparison of Burned and Unburned Areas of the Parks}

There are areas in both EVER and BICY where no fires have been recorded (fig. 13). The deepwatered, central area of Shark Slough is one such area. This region has never burned, even in the extreme drought years of 1982-83. Taylor Slough is another region with few or no fires. A third region includes the numerous coastal marshes among the mangrove forests along the southwestern coast of EVER. It is unclear why these marshes have not burned, as many of them have vegetation types, such as sawgrass (Cladium jamaicense), that burn elsewhere in the park. Early in EVER's history it is reasonable to suspect that some fires in these regions were simply missed by Park staff. The mangrove and marsh habitat on the southwestern coast of Everglades National Park is particularly remote and difficult to access. Another hypothesis is that these regions have different soil and sediment types and, therefore, are more resistant to fire.
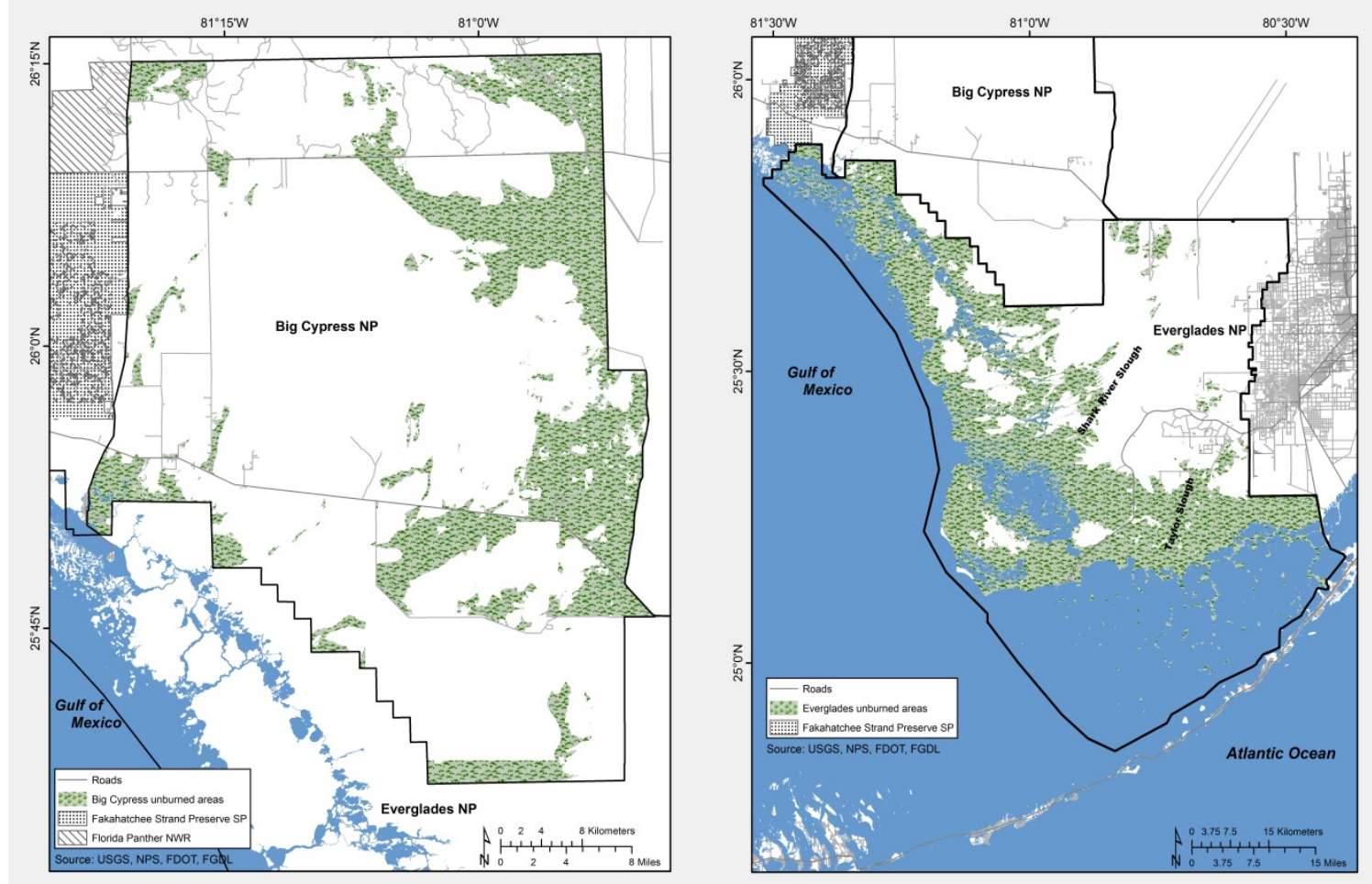

Figure 13. Maps showing unburned areas of Big Cypress National Preserve (BICY; left) and Everglades National Park, (EVER; right), southern Florida, based on combined fire history data from BICY (1978-2010) and ENP (1948-2010). 


\section{Fire Frequencies in the Parks}

Maps of total frequency of fires at both parks (fig. 14) during the study years were produced. Additionally, maps of fire frequency by type at each park (figs. 15 and 16) were created. Many areas in BICY have burned 10 or more times over the period of record. In EVER, some areas have burned 15 or more times. Most of these areas are in the pinelands, which historically were burned to prevent hardwood encroachment and, therefore, maintain the ecosystem as pine forest.

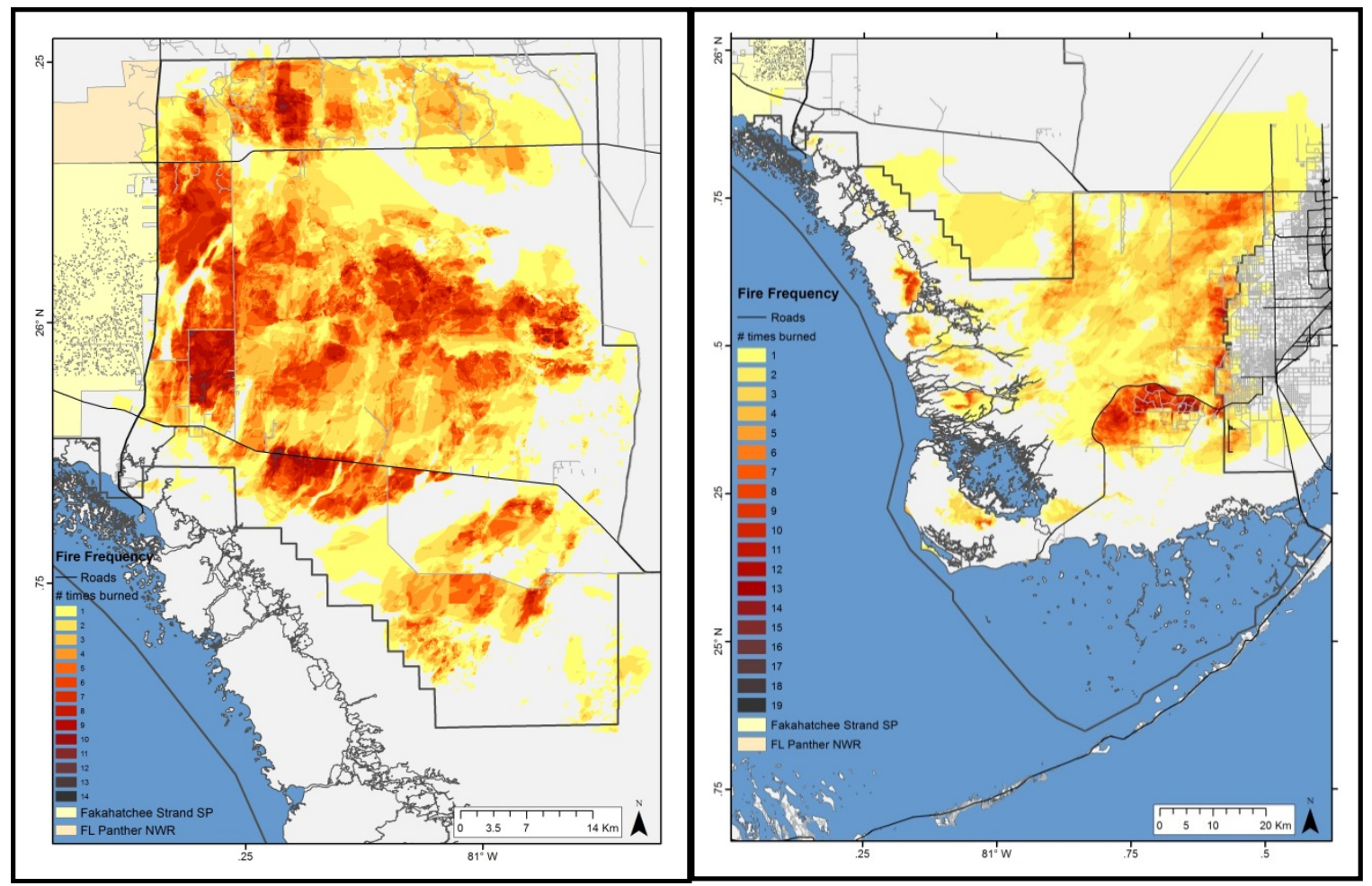

Figure 14. Maps showing total fire frequency based on data from fire management staff at Big Cypress National Preserve, 1978-2010 (left) and Everglades National Park, 1948-2010 (right), southern Florida. 


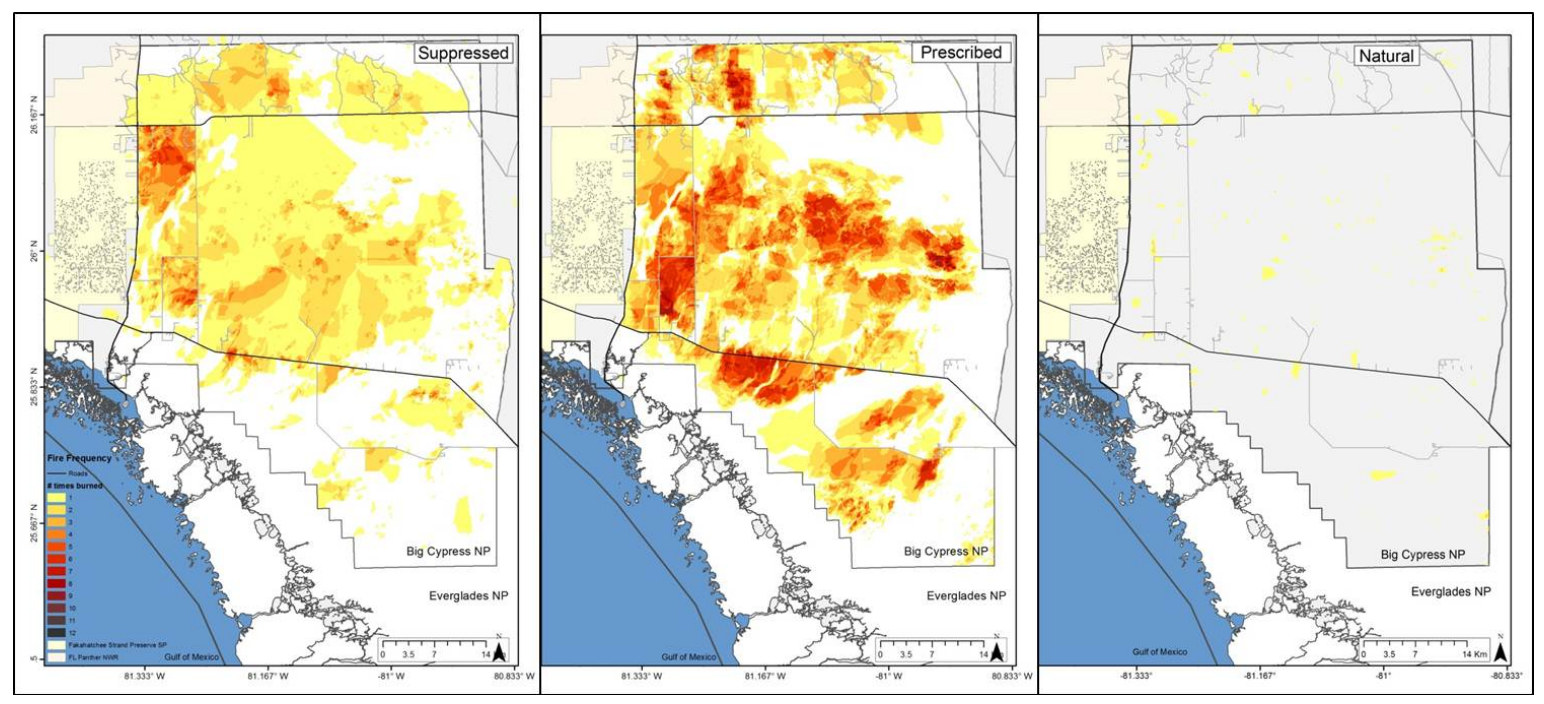

Figure 15. Maps showing total fire frequency by type based on data provided by fire management staff at Big Cypress National Preserve, 1978-2010, southern Florida.
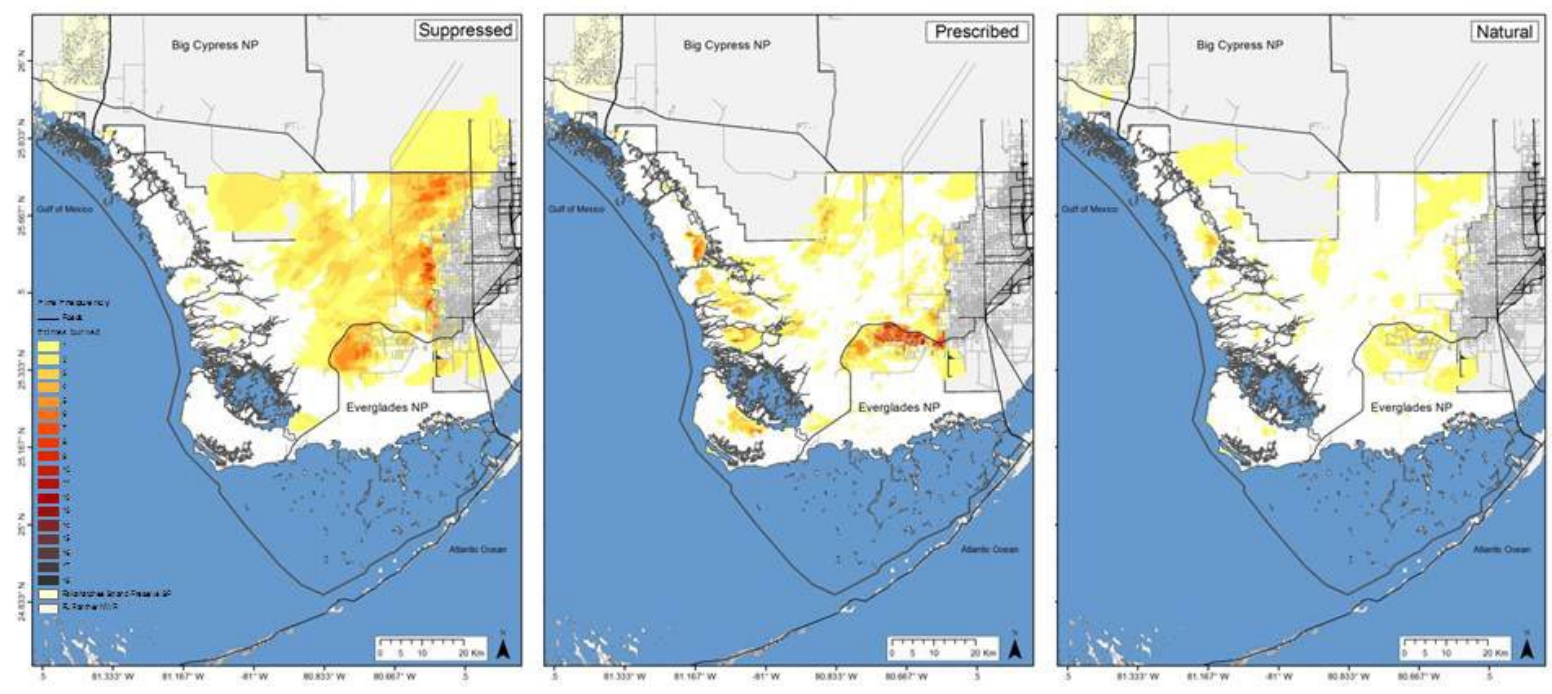

Figure 16. Maps showing total fire frequency by type based on data provided by fire management staff at Everglades National Park, 1948-2010, southern Florida. 


\section{Fires, Climate, and Water Level in Everglades National Park}

No relations between the number of fires and area burned were indicated as a function of the climate indices. For Natural fires only, there were no significant relations. However, for Natural plus Suppressed fires, the total number of fires was significantly and inversely related to March-June water levels at P33 (fig. 17). As water levels rise, the number of fires decreases. Although significant, the amount of variation explained was low $\left(\mathrm{R}^{2}=0.07, \mathrm{~F}_{1,55}=4.04, \mathrm{p}<0.05\right)$. Additionally, the amount of area burned for Natural plus Suppressed fires (natural log transformed) was more strongly, and inversely related to water levels (fig. $18 ; \mathrm{R}^{2}=0.24, \mathrm{~F}_{1,55}=19.96, \mathrm{p}<0.001$ ).

The results of this study contrast with the results of Beckage and others (2003). Beckage and others (2003) found significant negative correlations between the number of fires and area burned for NINO-3, and significant, positive correlations between the number of fires and area burned and the SOI. We found no significant relation between these climate indices and the number of fires or area burned. This discrepancy in findings probably is a result of the dataset that Beckage and others (2003) used. They used an older version of the fire history geodatabase than the version used in this study, and their version had numerous errors.

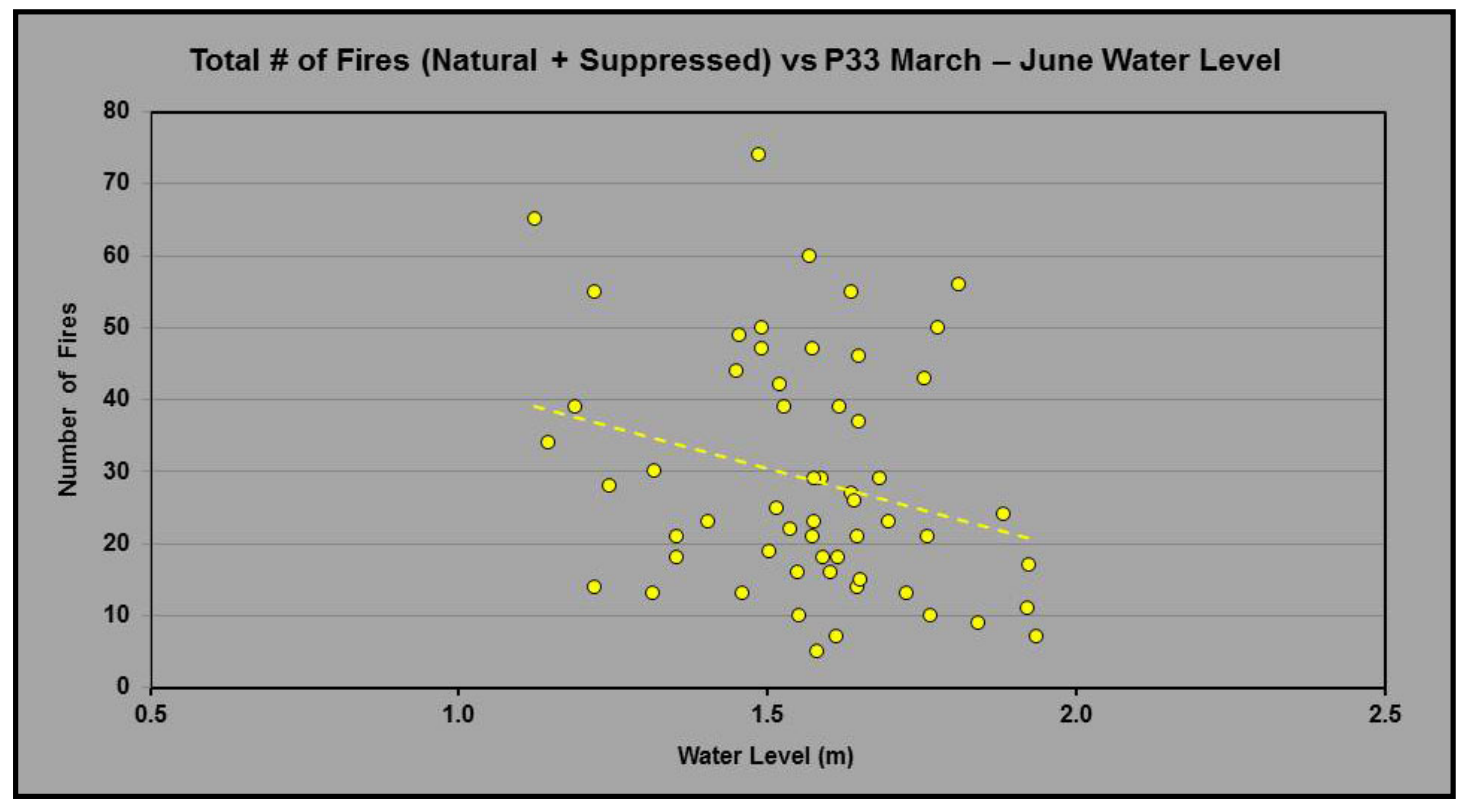

Figure 17. Graph showing total number of fires compared to March-June water levels at Everglades Depth Estimation Network station P33, Everglades National Park, 1948-2010, southern Florida. 


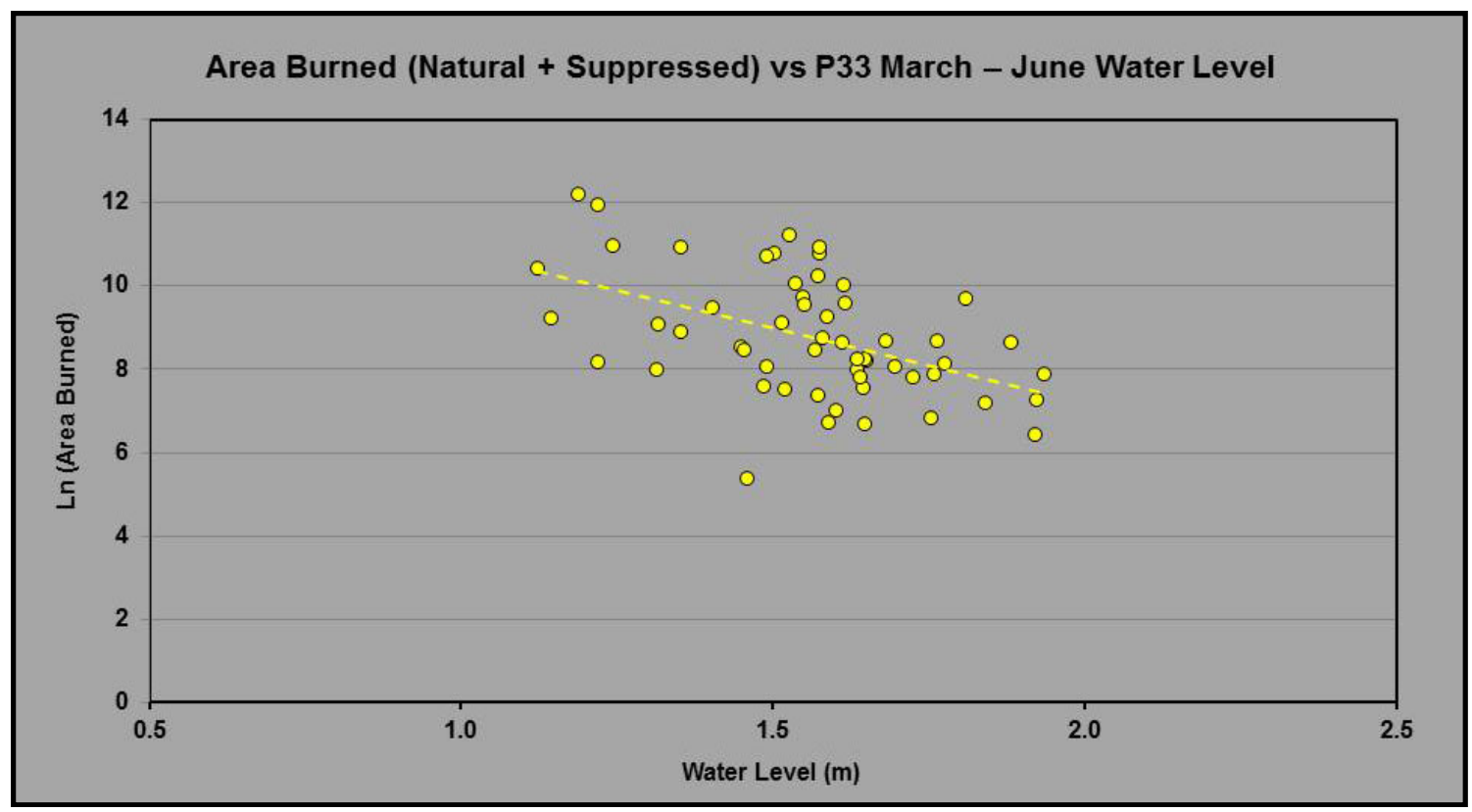

Figure 18. Graph showing total area burned compared to March-June water levels at Everglades Depth Estimation Network station P33, Everglades National Park, 1948-2010, southern Florida.

\section{Potential Future Research Activities}

The fire databases developed through this work serve as a foundation for additional research on fire, ecology, and resource management in the Greater Everglades area. For example, these databases are proving useful in the monitoring of post-fire vegetation dynamics, recovery, and fuel loads using satellite data (Jones and others, 2013; fig. 19). The analyses presented here are fairly narrow in scope. The Fire History database can be further analyzed to generate more information that will be useful to park resource management staff. The following is a short and certainly incomplete list of potential future directions for fire ecology research in the parks:

1. Relate occurrence of fires to habitat. None of the analyses examined marsh type. Do sawgrass marshes burn more frequently than bunchgrass marshes? Do low-salinity wetlands burn more often than high salinity wetlands in the parks?

2. Is there a spatial pattern to occurrence of fire in the parks? Habitats do not occur randomly, and the analyses suggest spatial patterns in the fire data.

3. Is occurrence of fire related to soil or sediment type? Soils and sediment also vary across the southern Florida landscape. Soils and sediment can be highly organic, mineral, or marl (Egler, 1952). Does this have any influence on fire? 
4. Can cost-effective, automated, remote sensing techniques be developed that refine burn scar perimeters, characterize within-perimeter burn variability, and perhaps even identify the presence of undiscovered fires in the Everglades region?

5. In addition to the climate indices and hydrology described in this report, examination of relations among fire occurrence and type, climate-related factors (for example, changes in precipitation and sea-level rise), extreme events (that is, hurricanes), and water resource management also are now possible with greater precision and accuracy.

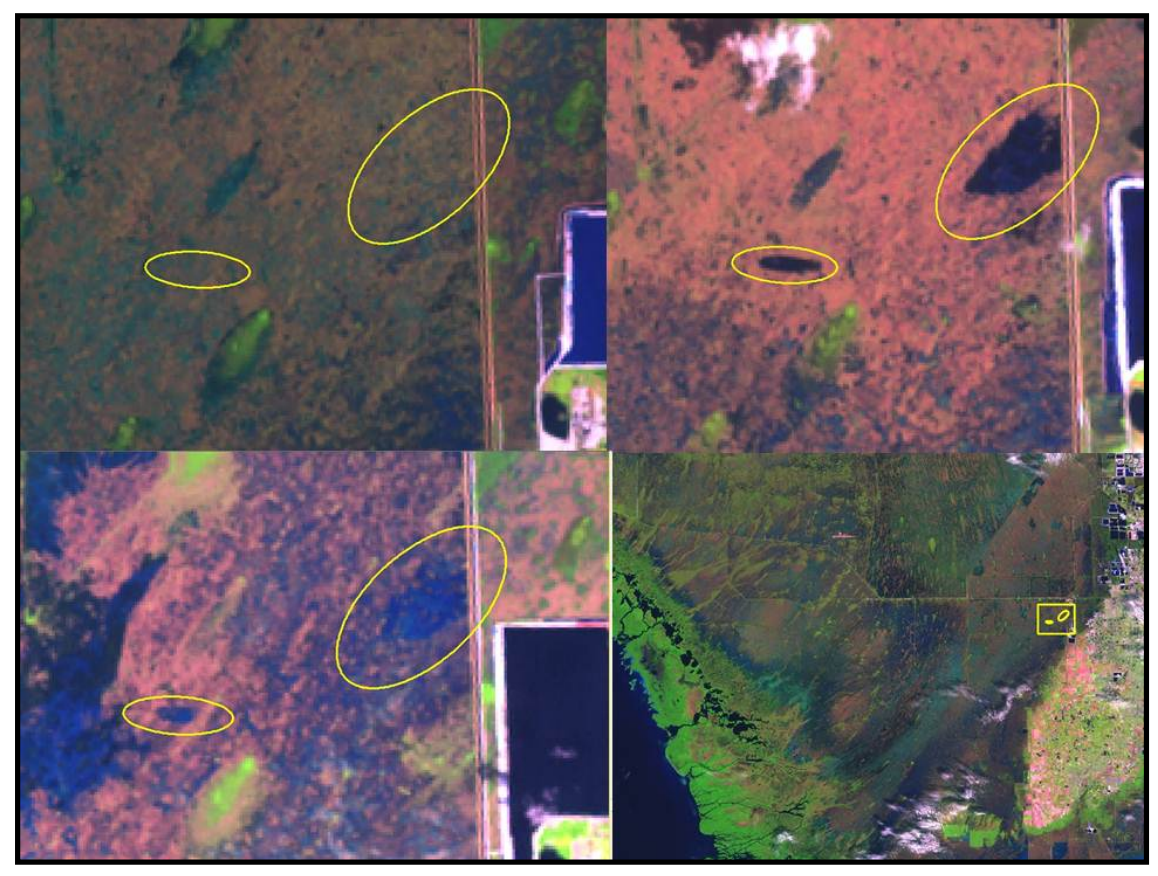

Figure 19. Landsat Thematic Mapper satellite images showing study area in 2000 before the fires (upper left), in 2004 immediately following the fires (upper right), in 2011 providing evidence for lack of vegetation recovery (lower left). Lower right panel shows Everglades National Park and Big Cypress National Preserve, southern Florida. The yellow box in the lower right panel shows the location of the fires shown in the other three panels. The site is in northeastern Shark Slough. 


\section{Acknowledgments}

The authors thank the following National Park Service employees for their contributions to this work: Jennifer Adams, Rick Anderson, Kevin Ash, Melissa Hood-Julien, Tristan Holland, Savannah Howington, Michal Jones, Carly Knoell, Dave Loveland, Roberto Palma, Bob Panko, Michael Suharmadji, Maya Vaidya, Kelly Watkins, and Mindy Wright. The authors also thank the following U.S. Geological Survey employees for their assistance and comments: Kristy Capobianco, Alisa Coffin, Andrew Garfield, Andrew Horan, Ursula Nash, Financial support for this project was provided by Everglades National Park under Interagency Agreements \#NPSAI2380-99-002 and \#F5284050010. Additional support came from the Greater Everglades Priority Ecosystems Studies, the Land Remote Sensing, and the Land Change Science programs of the U.S. Geological Survey, as well as the U.S. Geological Survey National Climate Change and Wildlife Science Center. The authors extend a special "thanks" to Drs. G. Ronnie Best and T. Douglas Beard, Jr. for their support.

\section{References Cited}

Bancroft, L., 1976, Fire management in Everglades National Park: Fire Management, v. 37, p. 18-21. Barnston, A.G., and Livezey, R.E., 1987, Classification, seasonality and persistence of low-frequency atmospheric circulation patterns: Monthly Weather Review, v. 115, p. 1,083-1,126.

Beard, D., 1938, Wildlife Reconnaissance of the Everglades National Park Project: U.S. Department of Interior, $106 \mathrm{p}$ mimeograph.

Beckage, B., and Platt, W.J., 2003. Predicting severe wildfire years in the Florida Everglades: Frontiers in Ecology and the Environment, v. 1, p. 235-239.

Beckage, B., Platt, W.J., Slocum, M.G., and Panko, B., 2003, Influence of the El Nino Southern

Oscillation on fire regimes in the Florida Everglades: Ecology, v. 84, p. 3,124-3,130.

Boerner, R.E.J., Huang, J., and Hart, S.C., 2009, Impacts of fire and fire surrogate treatments on forest soil properties - A meta-analytical approach: Ecological Applications, v. 19, p. 338-358.

Briggs, J.M., Knapp, A.K., Blair, J.M., Heisler, J.L., Hoch, G.A., Lett, M.S., and McCarron, J.K., 2005, An ecosystem in transition-Causes and consequences of the conversion of mesic grassland to shrubland: BioScience, v. 55, p. 243-254.

Chokkalingam, U., Suyanto, P.R.P., Kurniawam, I., Mannes, J., Darmawan, A., Khususyiah, N., and Susanto, R.H., 2007, Community fire use, resource change, and livelihood impacts-The downward spiral in the wetlands of southern Sumatra: Mitigation and Adaptation Strategies for Global Change, v. 12 , p. $75-100$.

Cohen, A.D., 1984, Evidence of fires in the ancient Everglades and coastal swamps of Florida, in Gleason, P.J., ed., Environments of South Florida_-Past and Present (2d ed.): Miami, Florida, Miami Geological Society, p. 459-464.

DeVries, D., Anderson, G.H., and Draughn, F., 1992, Applications of GPS/GIS for fire mapping in Everglades National Park, in Remote sensing and natural resource management: U.S. Forest Service, Fourth Forest Service Remote Sensing Applications Conference, p. 251-256, ISBN 0-944426-89-1.

Dovell, J.E., 1942, A brief history of the Florida Everglades: Proceedings of the Soil Science Society of Florida, IV-A, p. 132-161.

Egler, F., 1952, Southeast saline Everglades vegetation, Florida, and its management: Vegetatio, v. 3, p. 213-265.

Eshel, A., Henig-Sever, N., and Ne'eman, G., 2000, Spatial variation of seedling distribution in an east Mediterranean pine woodland at the beginning of post-fire succession: Plant Ecology, v.148, p. 175182. 
Fidelis, A., Muller, S.A., Pillar, V.D., and Pfadenhauer, J., 2010, Population biology and regeneration of forbs and shrubs after fire in Brazilian Campos grasslands: Plant Ecology, v. 211. p. 107-117.

Frost, C.C., 1995, Presettlement fire regimes in southeastern marshes, peatlands and swamps, in Cerulean, S., and Engstrom, R.T., Proceedings of the 19th Tall Timbers Fire Ecology Conference, Fire in wetlands - A management perspective, Tallahassee, Florida: Tall Timbers Research, Inc., Tallahassee, Florida, v. 19, p. 39-60.

Fuhlendorf, S.D., Harrell, W.C., Engle, D.M., Hamilton, R.G., Davis, C.A., and Leslie, D.H., Jr., 2006, Should heterogeneity be the basis for conservation? - Grassland bird response to fire and grazing: Ecological Applications, v. 16, p. 1,706-1,716.

Gonzalez, M.O., Veblen, T.M., and Sibold, J.S., 2005, Fire history of Araucaria-Nothofagus forests in Villarrica National Park, Chile: Journal of Biogeography, v. 32, p. 1,187-1,202.

Grant, T.A., Flanders-Wanner, B., Shaffer, T.L., Murphy, R.K., and Knutsen, G.A., 2009, An emerging crisis across northern prairie refuges - Prevalence of invasive plants and a plan for adaptive management: Ecological Restoration, v. 27, p. 58-65.

Heisler, J.L., Briggs, J.M., and Knapp, A.K., 2003, Long-term patterns of shrub expansion in a $\mathrm{C}_{4}$ dominated grassland-Fire frequency and the dynamics of shrub cover and abundance: American Journal of Botany, v. 90, p. 423-428.

Holt, E.G., and Sutton, G.M., 1926, Notes on birds observed in southern Florida: Annals of the Carnegie Museum, v. 16, p. 409-439.

Jones, J.W., Hall, A.E., Foster, A.M., and Smith, T.J., III, 2013, Everglades fire scar monitoring and analysis using archival Landsat data: Fire Ecology, v.9, no. 1, p. 133-150.

Karamperidou, C., Engel, V., Lall, U., Stabenau, E., and Smith, T.J., III, 2013, Implications of multiscale sea level and climate variability for coastal resources-A case study for south Florida and Everglades National Park, Regional Environmental Change, 13, Suppl 1, S91-S100.

Kauhanen, H., 2008, Forest fires in the Russian taiga, in Hovi, M., and Kyto, H., and Rautio, eds., Fire and forest-The International Forest Fire Symposium: Helsinki, Finland, Metsähallitus, p. 27-33.

Keith, D.A., Rodoreda, S., and Beward, M., 2010, Decadal change in wetland-woodland boundaries during the late 20th century reflects climatic trends: Global Change Biology, v. 16, p. 2,300-2,306.

Klukas, R.W., 1973, Control burn activities in Everglades National Park, in Proceedings of the 12th Tall Timbers Fire Ecology Conference, A quest for ecological understanding, Lubbock, Texas: Tall Timbers Research, Inc., Tallahassee, Florida, v. 12, p. 397-425.

Kutt, A.S., and Woinarski, J.C.Z., 2007, The effects of grazing and fire on vegetation and the vertebrate assemblage in a tropical savanna woodland in north-eastern Australia: Journal of Tropical Ecology, v. 23, p. 95-106.

Lynch, J.J., 1941, The place of burning in management of the Gulf Coast wildlife refuges: Journal of Wildlife Management, v. 5, p. 454-457.

Mack, M.C., Treseder, K.K., Manies, K.L., Harden, J.W., Schuur, E.A.G., Vogel, J.G., Randerson, J.G., and Chapin, F.S., 2008, Recovery of aboveground plant biomass and productivity after fire in mesic and dry black spruce forests of interior Alaska: Ecosystems, v. 11, p. 209-225.

Mantua, N.J., Hare, S.R., Zhang, Y., Wallace, J.M., and Francis, R.C., 1997, A Pacific interdecadal climate oscillation with impacts on salmon production: Bulletin of the American Meteorological Society, v. 78, p. 1069-1079.

McGlone, M., Wilmshurst, J., and Meurk, C., 2007, Climate, fire, farming and the recent vegetation history of subantarctic Campbell Island: Earth and Environmental Science Transactions of the Royal Society of Edinburgh, v. 98, p. 71-84. 
Miehe, G., Miehe, S., Schultz, F., Kaiser, K., and Duo, L., 2006, Palaeoecological and experimental evidence of former forests and woodlands in the treeless desert pastures of Southern Tibet (Lhasa, A.R. Xizang, China): Palaeogeography, Palaeoclimatology, Palaeoecology, v. 242 p. 54-67.

Miller, J.D., Safford, Crimmins, M., and Thode, A.E., 2009, Quantitative evidence for increasing forest fire severity in the Sierra Nevada and Southern Cascade Mountains, California and Nevada, USA: Ecosystems, v. 12, p. 16-32.

Peterson, D.W., and Reich, P.B., 2008, Fire frequency and tree canopy structure influence plant species diversity in a forest-grassland ecotone: Plant Ecology, v. 194, p. 5-16.

Phillippe, L.R., Feist, M.A., Busemeyer, D.T., Marcum, P.M., Carroll, C.J., Spyreas, G.R., and Ebinger, J.E., 2011, Vegetation of forest and savanna communities on glacial sand deposits in northeastern Illinois: The Southwestern Naturalist, v. 56, p. 54-60.

Phillips, W.S., 1940, A tropical hammock on the Miami (Florida) limestone: Ecology, v. 21 , p. 166175.

Power, M.J., and others, 2008, Changes in fire regimes since the Last Glacial Maximum:-An assessment based on a global synthesis and analysis of charcoal data: Climate Dynamics, v. 30, p. 887-907.

Robertson, W.B., Jr., 1953, A survey of the effects of fire in Everglades National Park: Report to the U.S. Department of Interior, National Park Service, 169 p. http://sofia.usgs.gov/publications/reports/wlrecon_enp/index.html

Robertson, W.B., Jr., 1962, Fire and vegetation in the Everglades, Proceedings of the First Tall Timbers Fire Ecology Conference, Tallahassee, Florida: Tall Timbers Research, Inc., Tallahassee, Florida, v. 1, p. 67-80.

Ryan, C.M., and Williams, M., 2011, How does fire intensity and frequency affect miombo woodland tree populations and biomass?: Ecological Applications, v. 21, p. 48-60.

Scheintaub, M.R., Derner, J.D., Kelly, E.F., and Knapp, A.K., 2009, Response of the shortgrass steppe plant community to fire: Journal of Arid Environments, v. 73, p. 1,136-1,143.

Schlesinger, M.E., and Ramankutty, N., 1994, An oscillation in the global climate system of period 6570 years: Nature, v. 367, p. 723-726.

Slocum, M.G., Platt, W.J., Beckage, B., Panko, B., and Lushine, J.B., 2007, Decoupling natural and anthropogenic fire regimes-A case study in Everglades National Park: Natural Areas Journal, v. 27, p. 41-55.

Small, J.K., 1916, A cruise to the Cape Sable region of Florida: Journal of the New York Botanical Garden, v. 17, p. 189-202.

Small, J.K., 1923, Green deserts and dead gardens: Journal of the New York Botanical Garden, v. 24, p. 193-247.

Small, J.K., 1924, The land where spring meets autumn: Journal of the New York Botanical Garden, v. 25, p. 53-94.

Small, J.K., 1930, Vegetation and erosion on the Everglades Keys: Scientific Monthly, v. 30, p. 33-49.

Smith, T.J., III, Foster, A.M., Tiling-Range, G., and Jones, J.W., 2013, Dynamics of mangrove-marsh ecotones in the Everglades-Fire, sea-level rise, and water levels: Fire Ecology, v. 9, no. 1, p. 66-77.

Staver, C.A., Archibald, S.A., and Levin, S.A., 2011, The global extent and determinants of savanna and forest as alternative biome states: Science, v. 234, p. 230-232.

Taylor, D.L., 1980, Summary of fires in Everglades National Park and Big Cypress National Preserve, 1979: South Florida Research Center Report T-595, 23 p.

Taylor, D.L., 1981, Fire history and fire records for Everglades National Park, 1948-1979: South Florida Research Center Report T-619, 121 p. 
Trenberth, K.E., 1984, Signal versus noise in the Southern Oscillation: Monthly Weather Review, v. 112 , p. 326-332.

Trenberth, K.E., 1997, The definition of El Nino: Bulletin of the American Meteorological Society, v. 78 , p. $2,771-2,777$.

Troup, A.J., 1965, The ‘southern oscillation': Quarterly Journal of the Royal Meteorological Society, v. 91, p. 490-506.

Van Auken, O.W., 2000, Shrub invasions of North American grasslands: Annual Review of Ecology and Systematics, v. 31, p. 197-215.

Van Wilgen, B.W., 1982, Some effects of post-fire age on the above-ground plant biomass of Fynbos (Macchia) vegetation in South Africa: Journal of Ecology, v. 70, p. 217-225.

Vasconcelos, H.L., Pacheco, R., Silva, R.C., Vasconcelos, P.B., Lopes, C.T., Costa, A.N., and Bruna, E.M., 2009, Dynamics of the leaf-litter arthropod fauna following fire in a neotropical woodland savanna: PLoS ONE, v. 4, no. 11, e7762, doi:10.1371/journal.pone.0007762.

Veblen, T.T., and Lorenz, D.C., 1988, Recent vegetation changes along the forest / steppe ecotone of northern Patagonia: Annals of the Association of American Geographers, v. 78, p. 93-111.

Wade, D., Ewel, J., and Hofstetter, R., 1980, Fire in south Florida ecosystems: U. S. Department of Agriculture, Forest Service General Technical Report SE-17, Asheville, North Carolina, 125 p.

Zong, Y., Chen, Z., Innes, J.B., Chen, C., Wang, Z., and Wang, H., 2007, Fire and flood management of coastal swamp enabled first rice paddy cultivation in east China: Nature, v. 449, p. 459-462. 
This page left intentionally blank 


\section{Appendix A. Maps of Fires in Everglades National Park by Year}
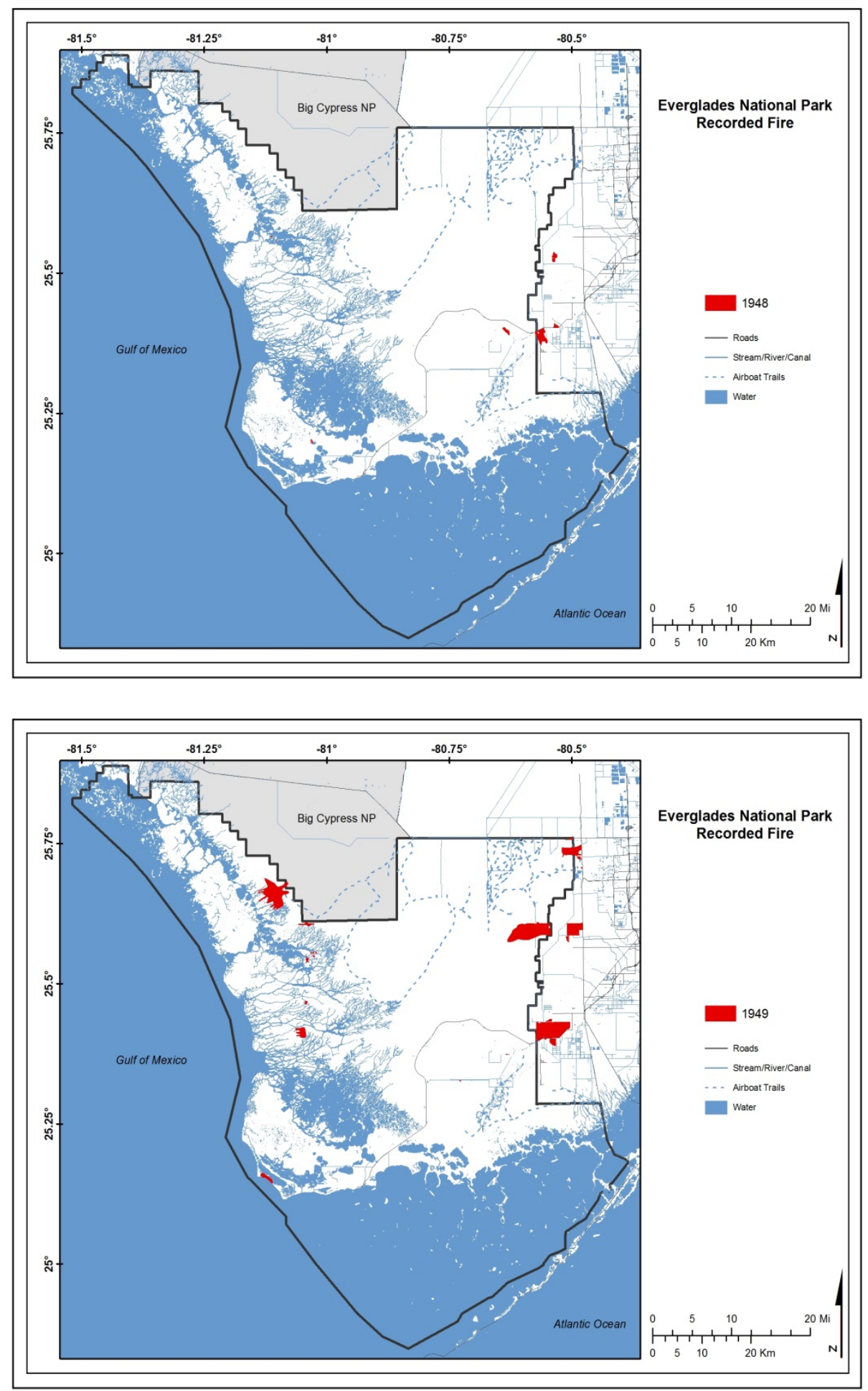

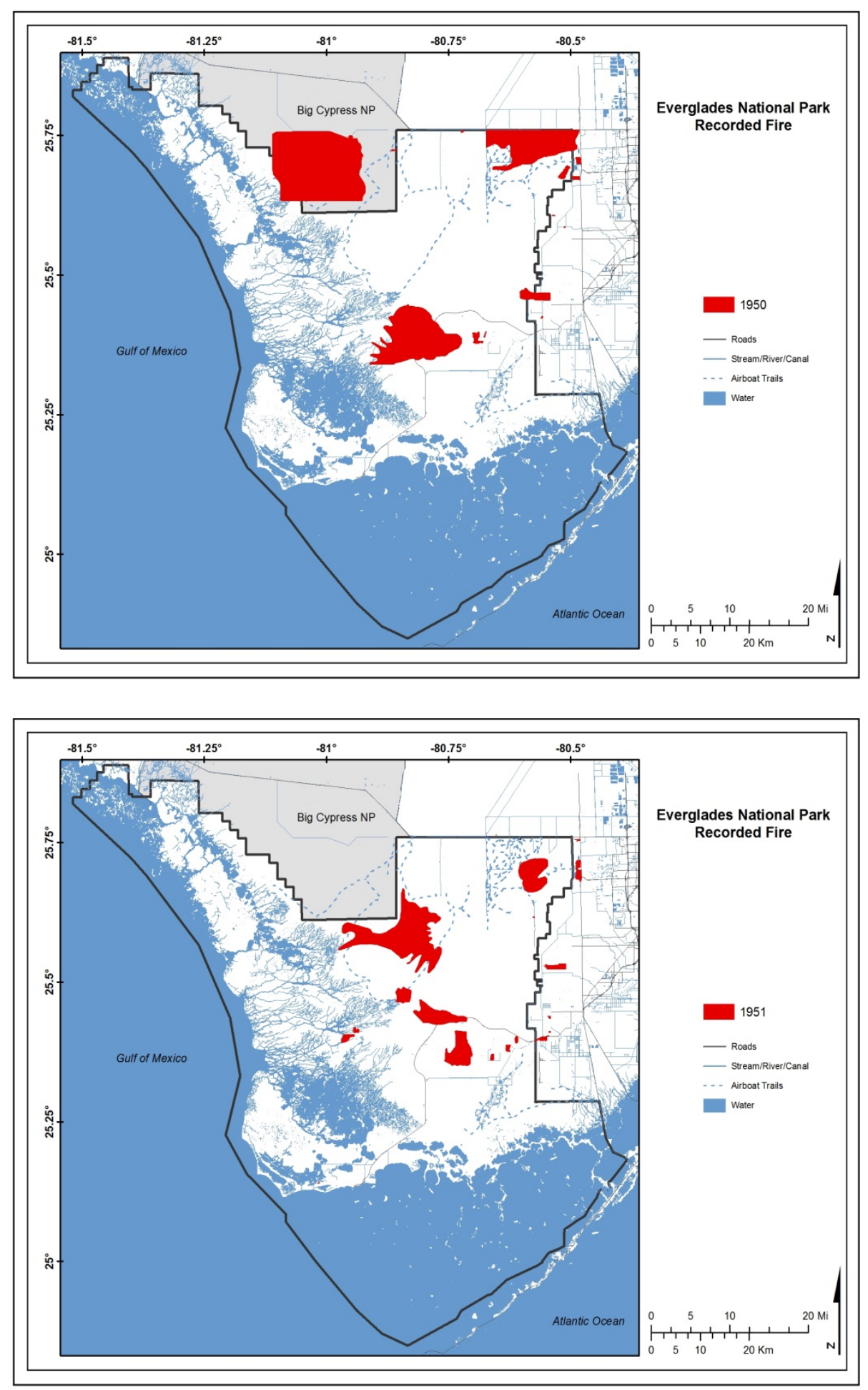

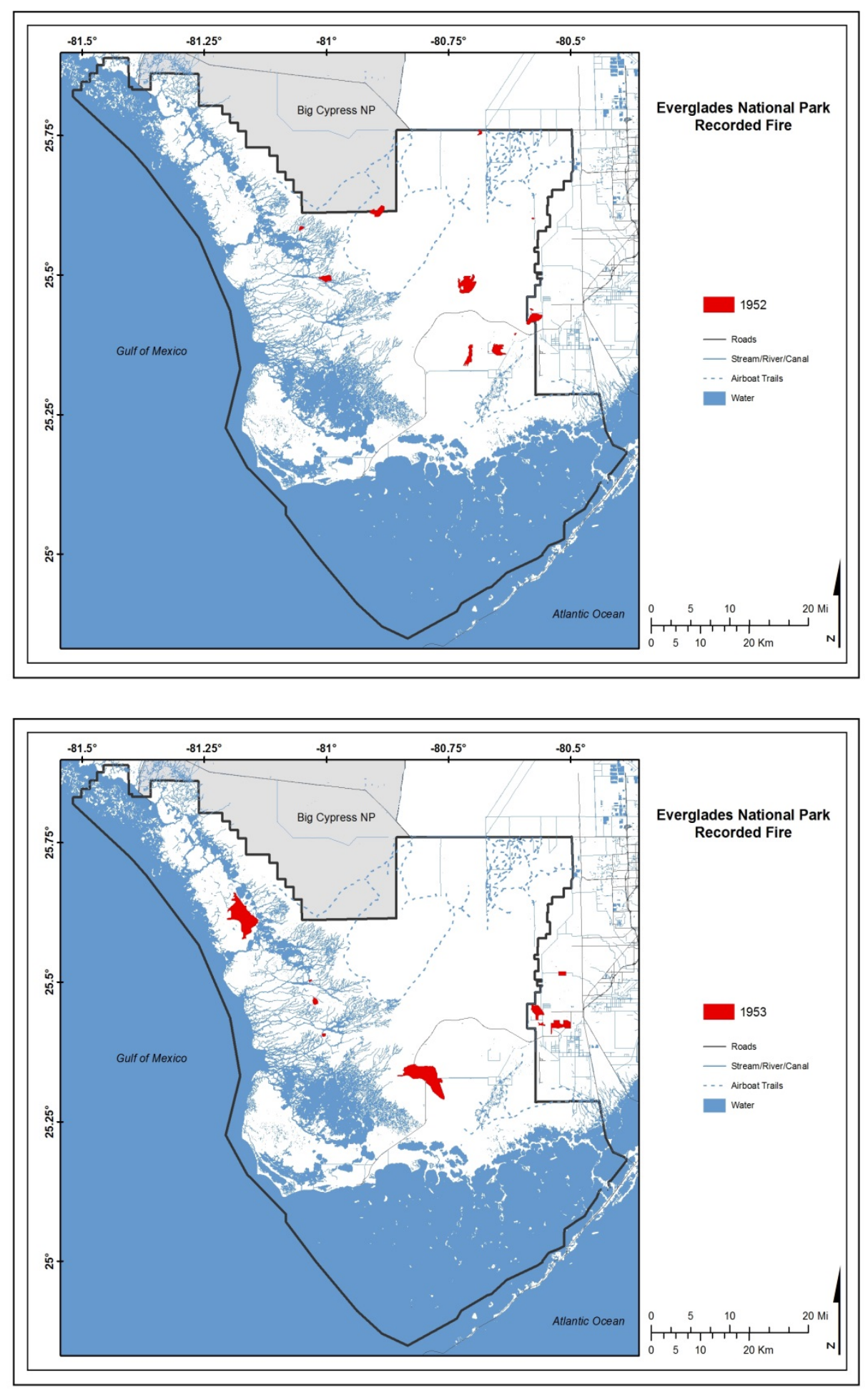

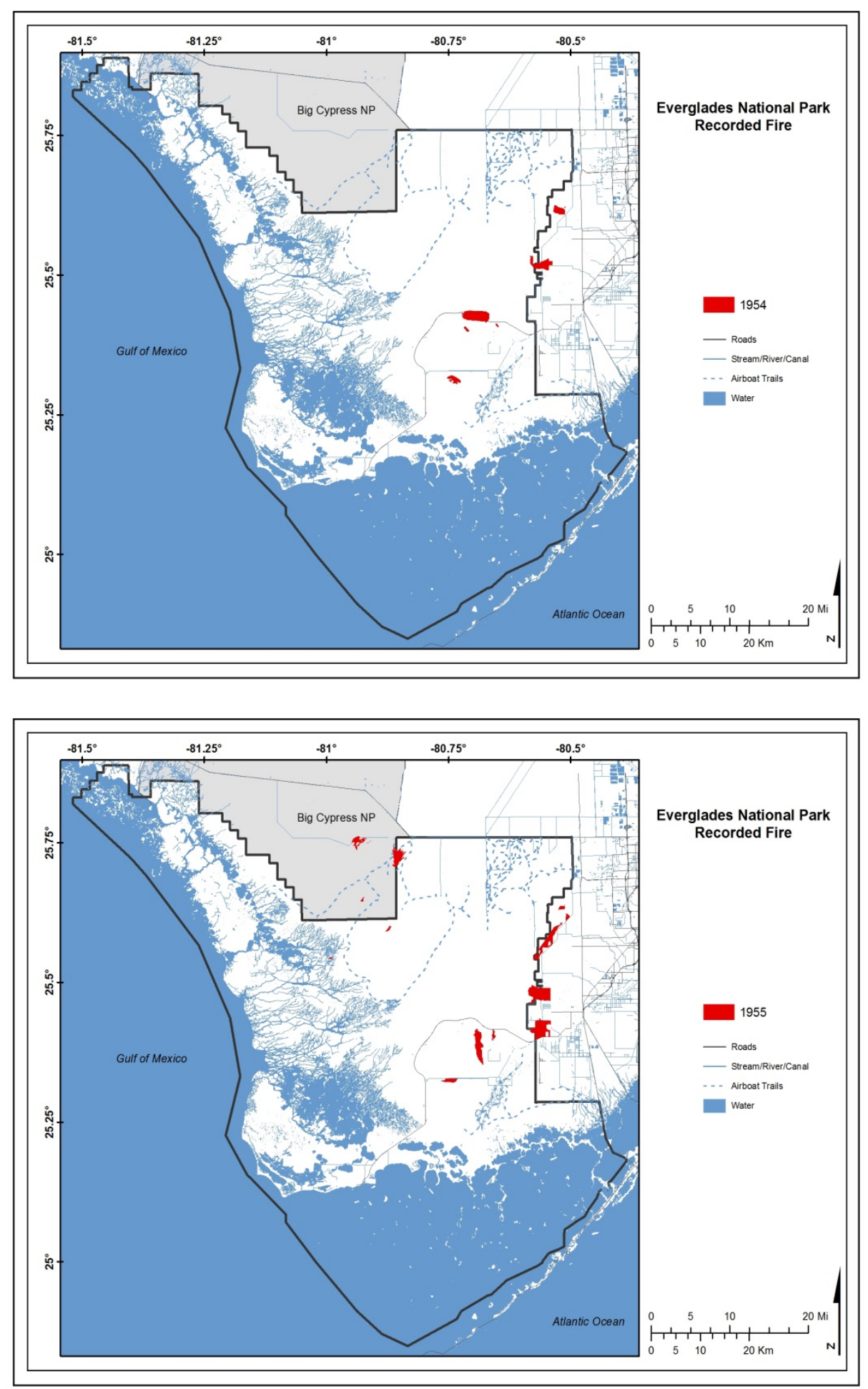

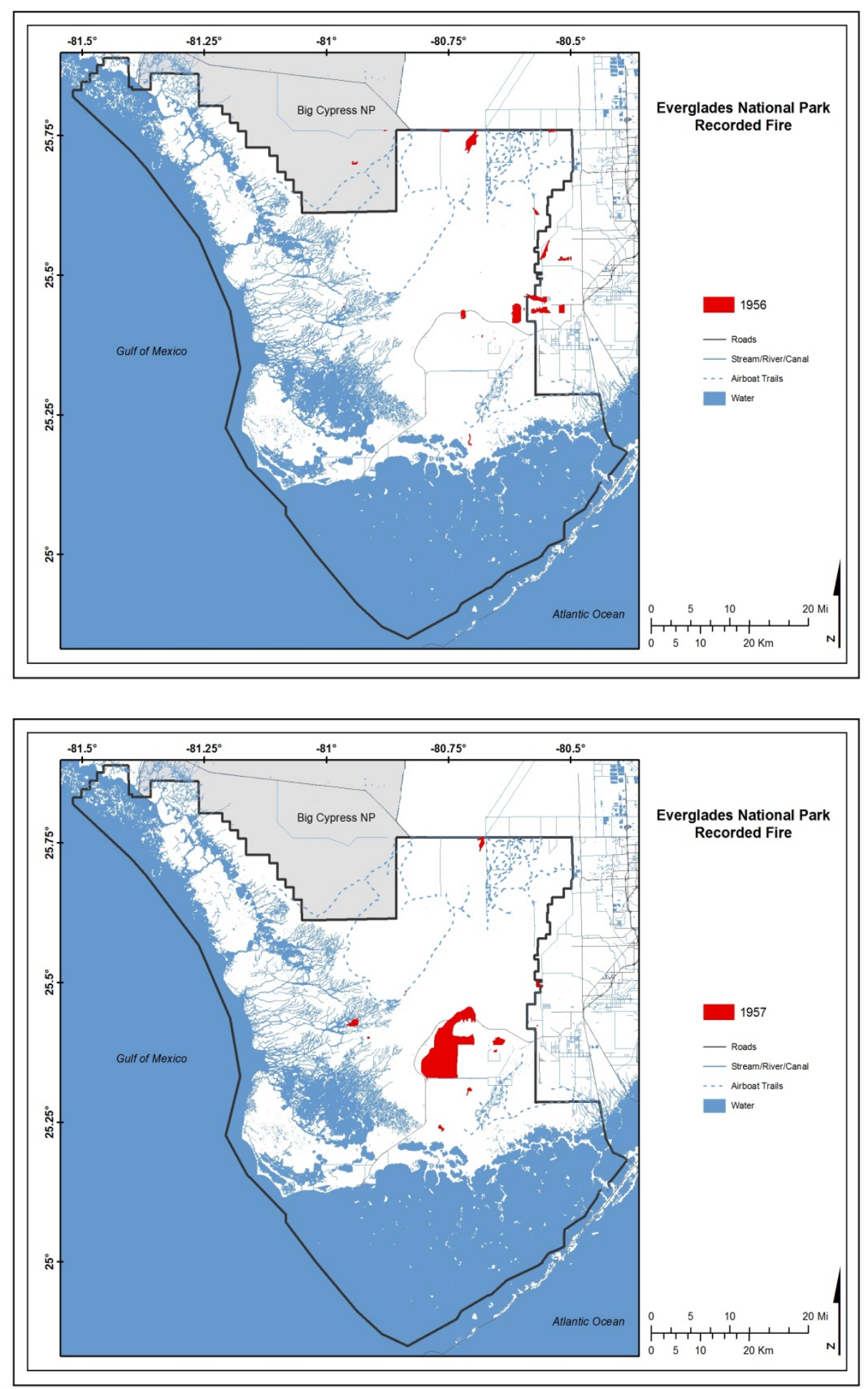

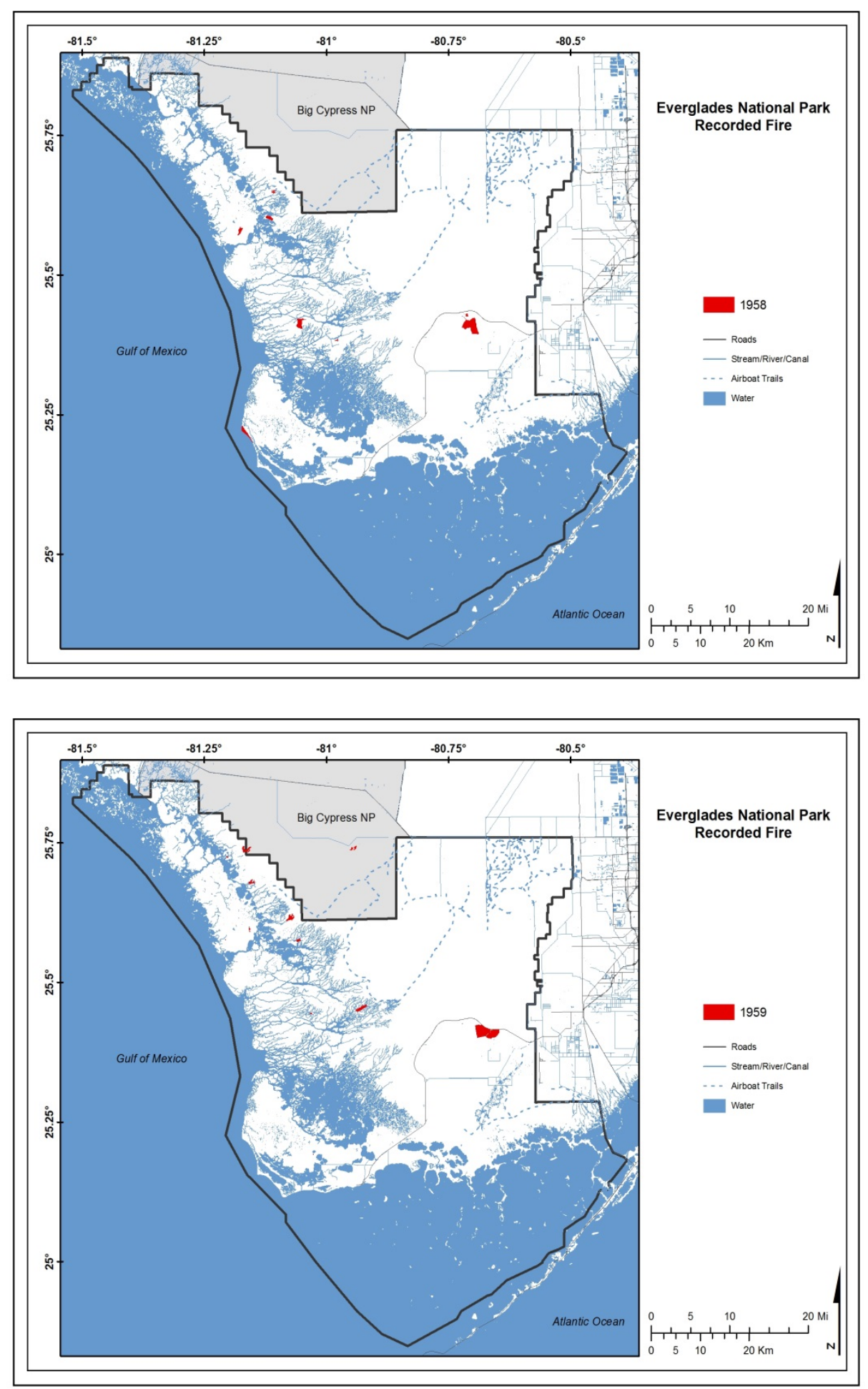

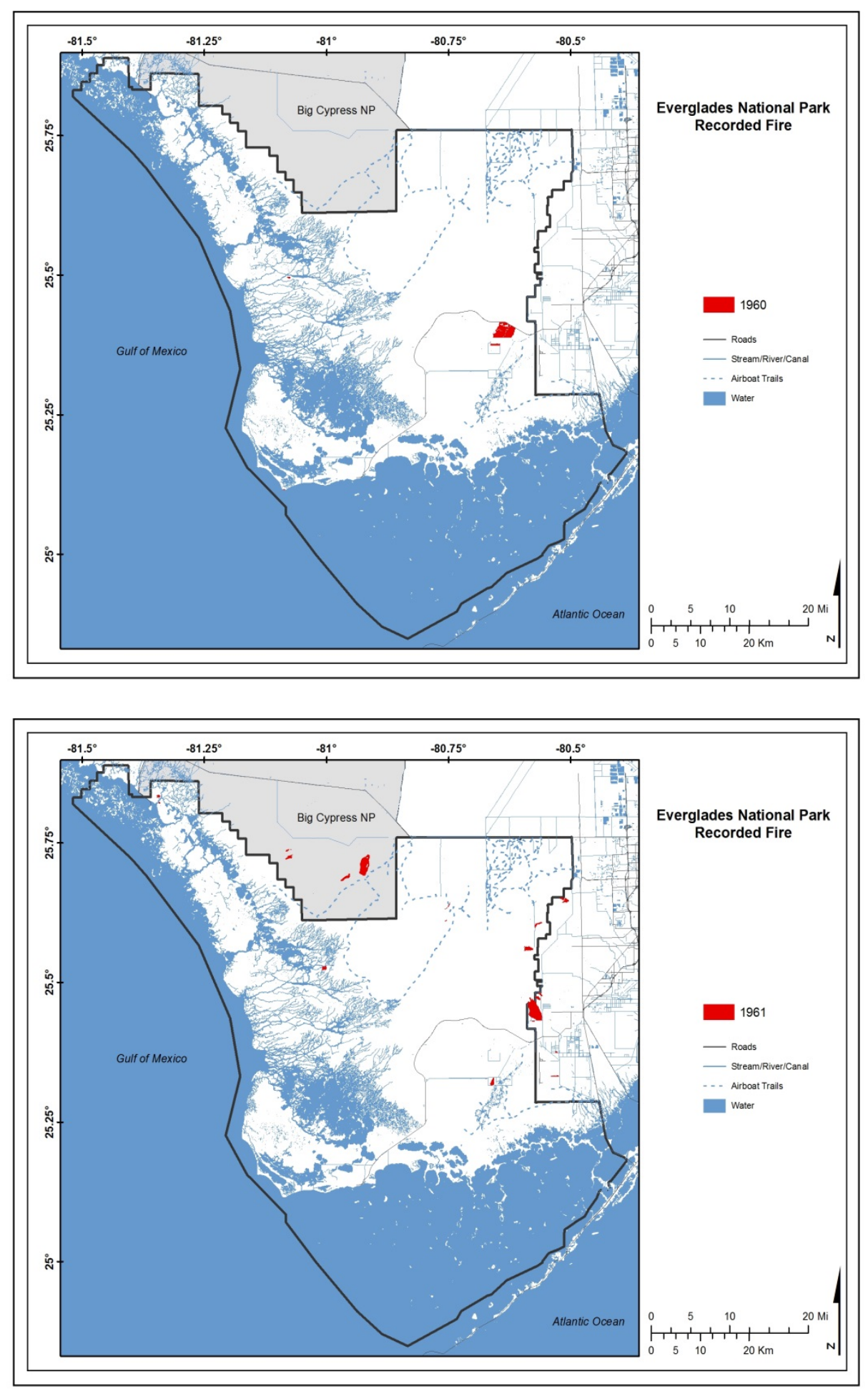

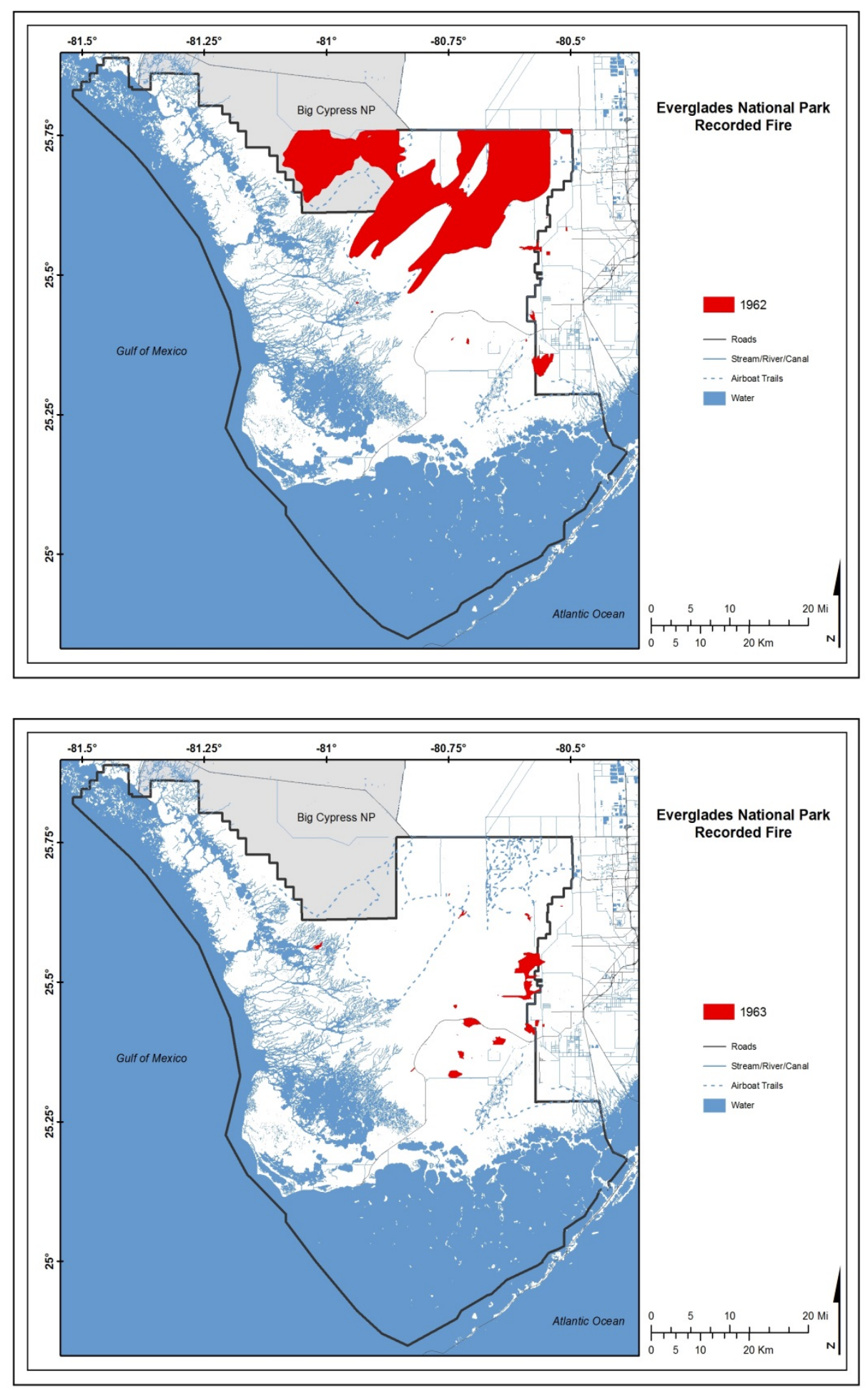

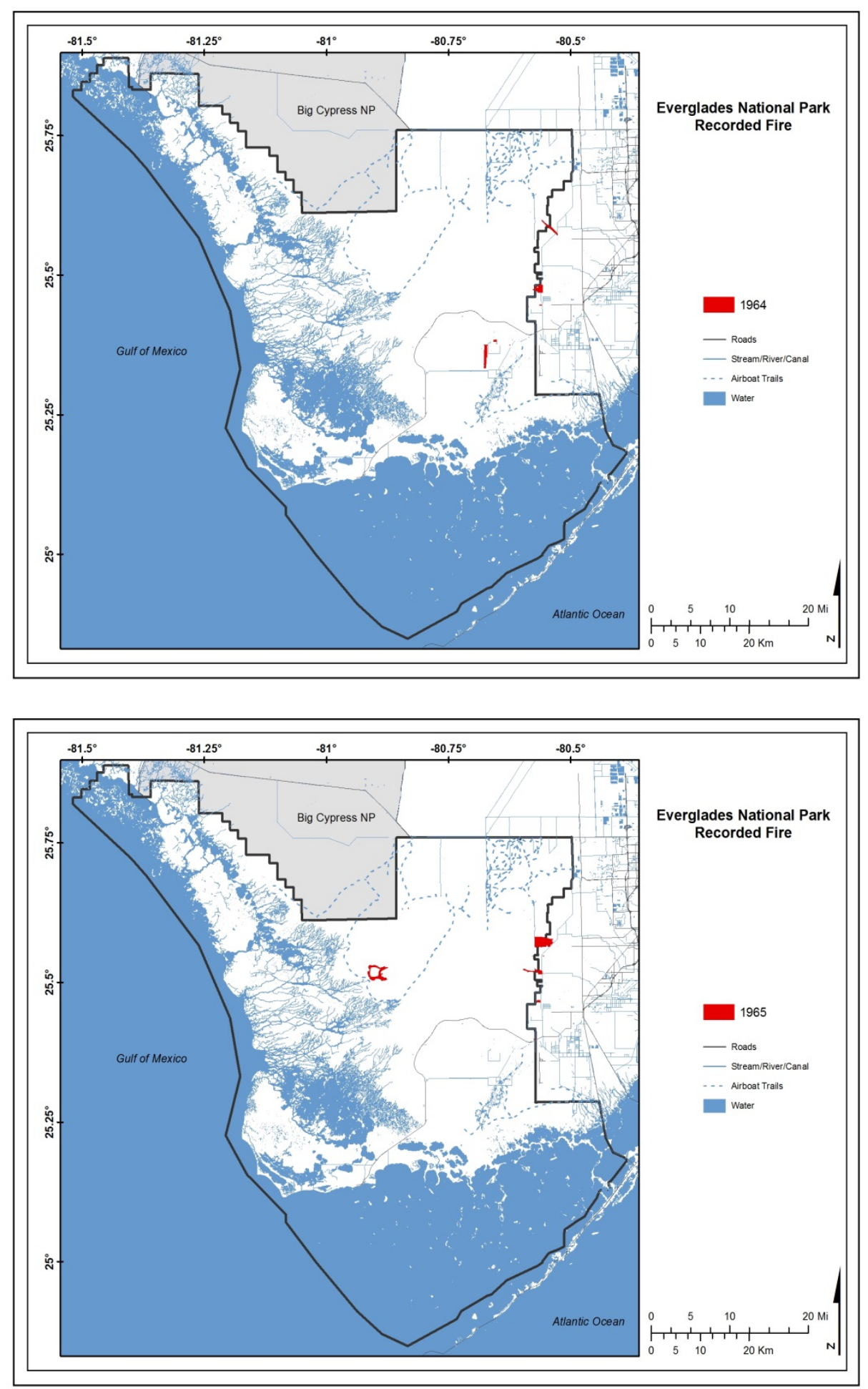

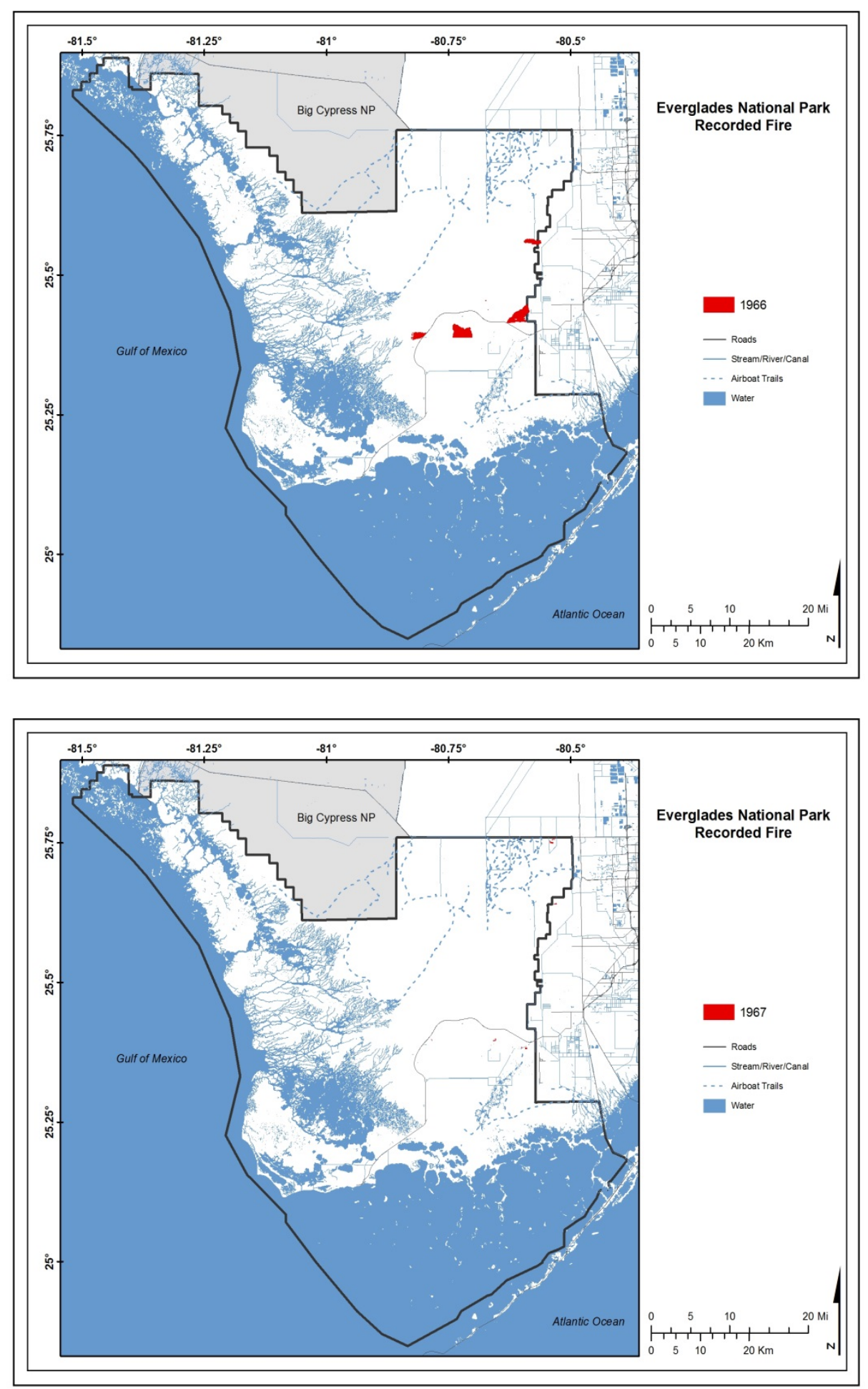

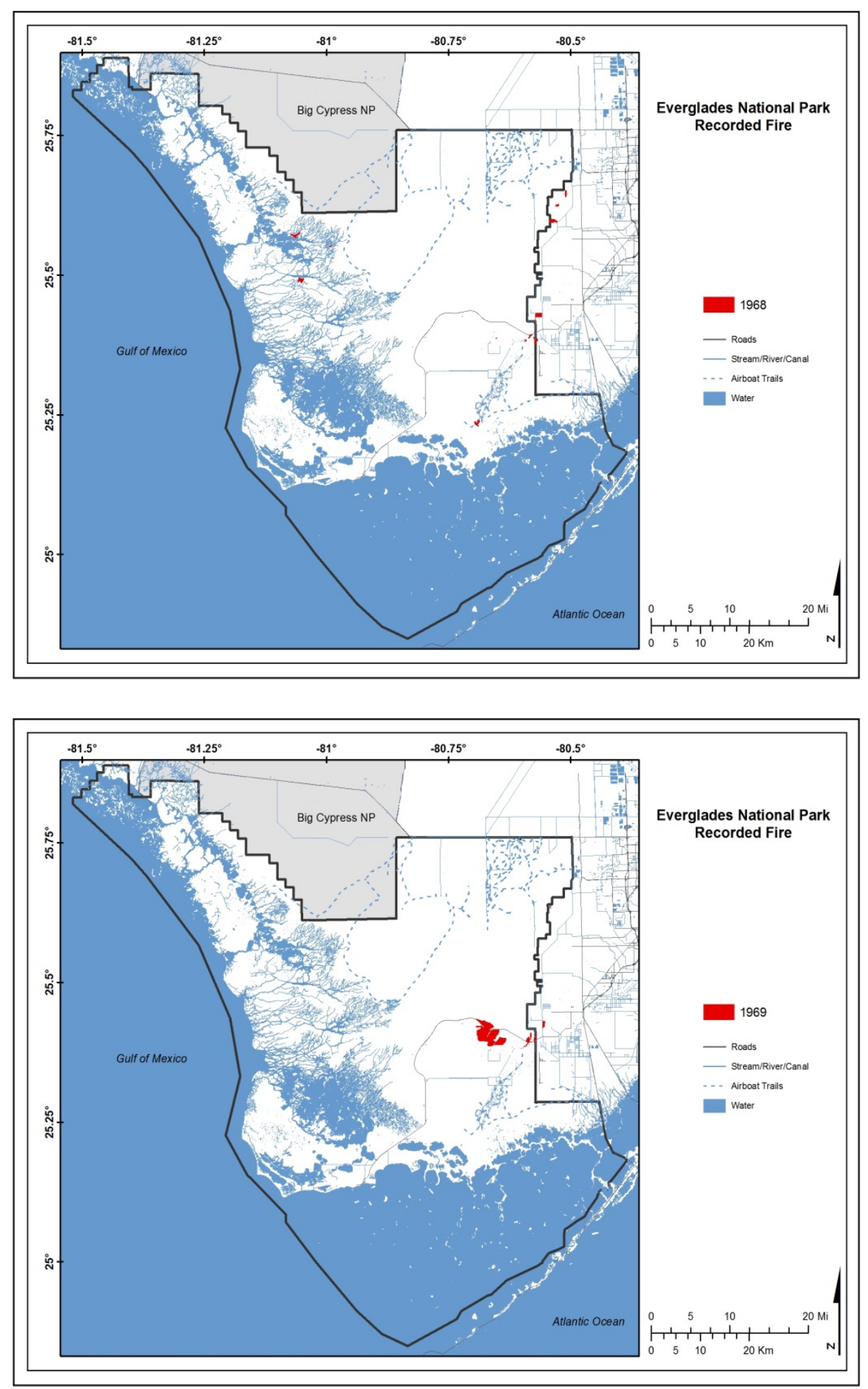

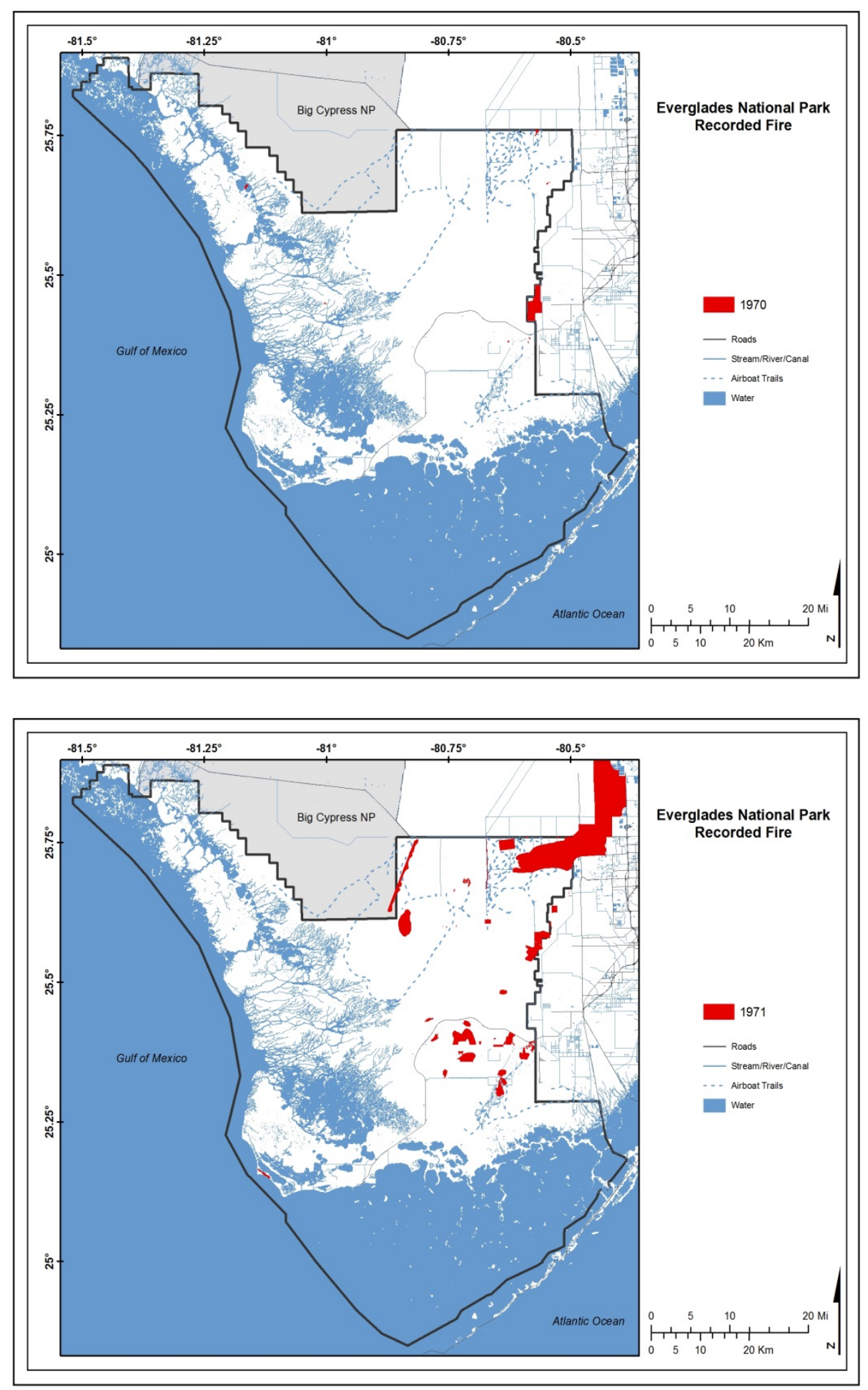

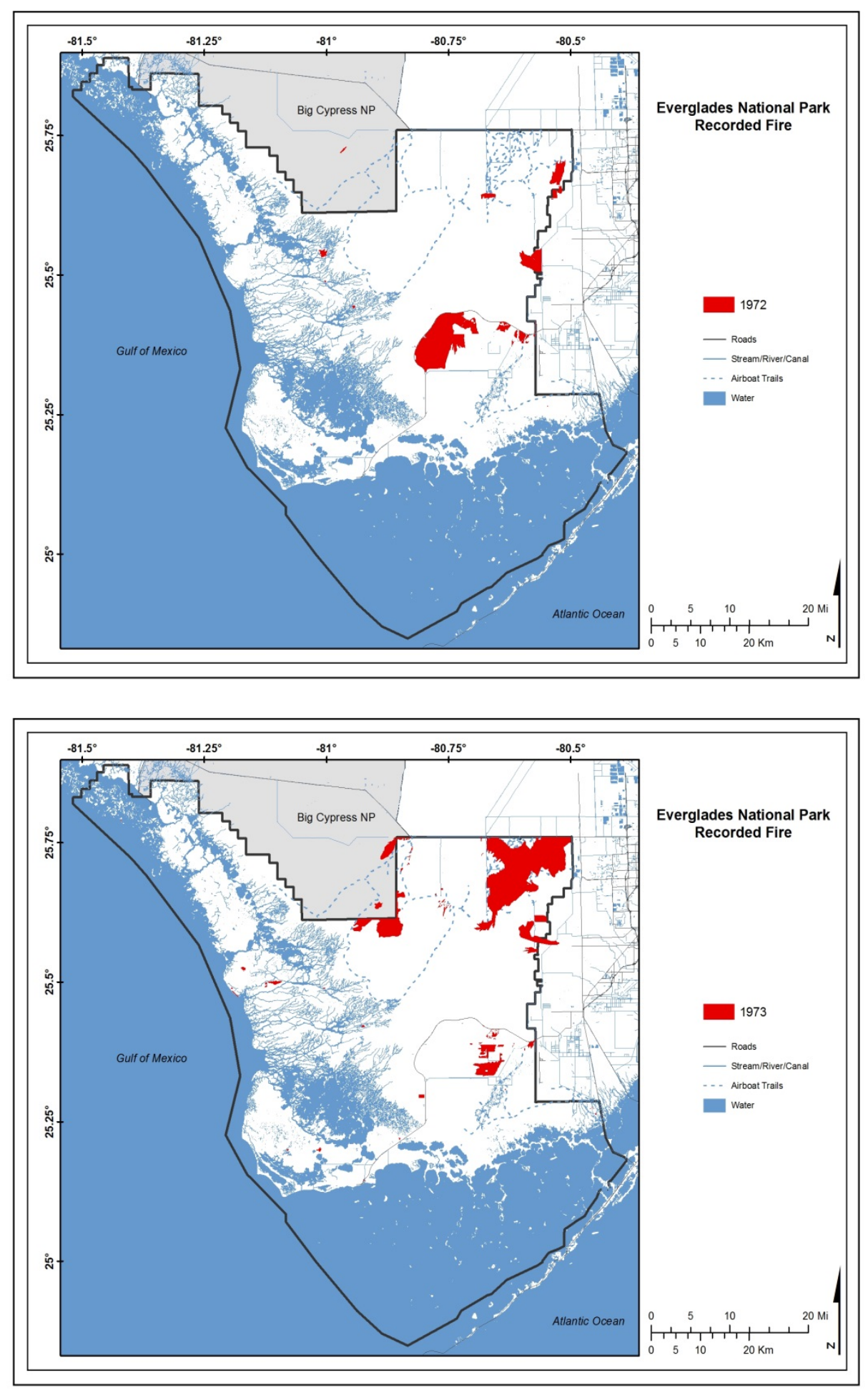

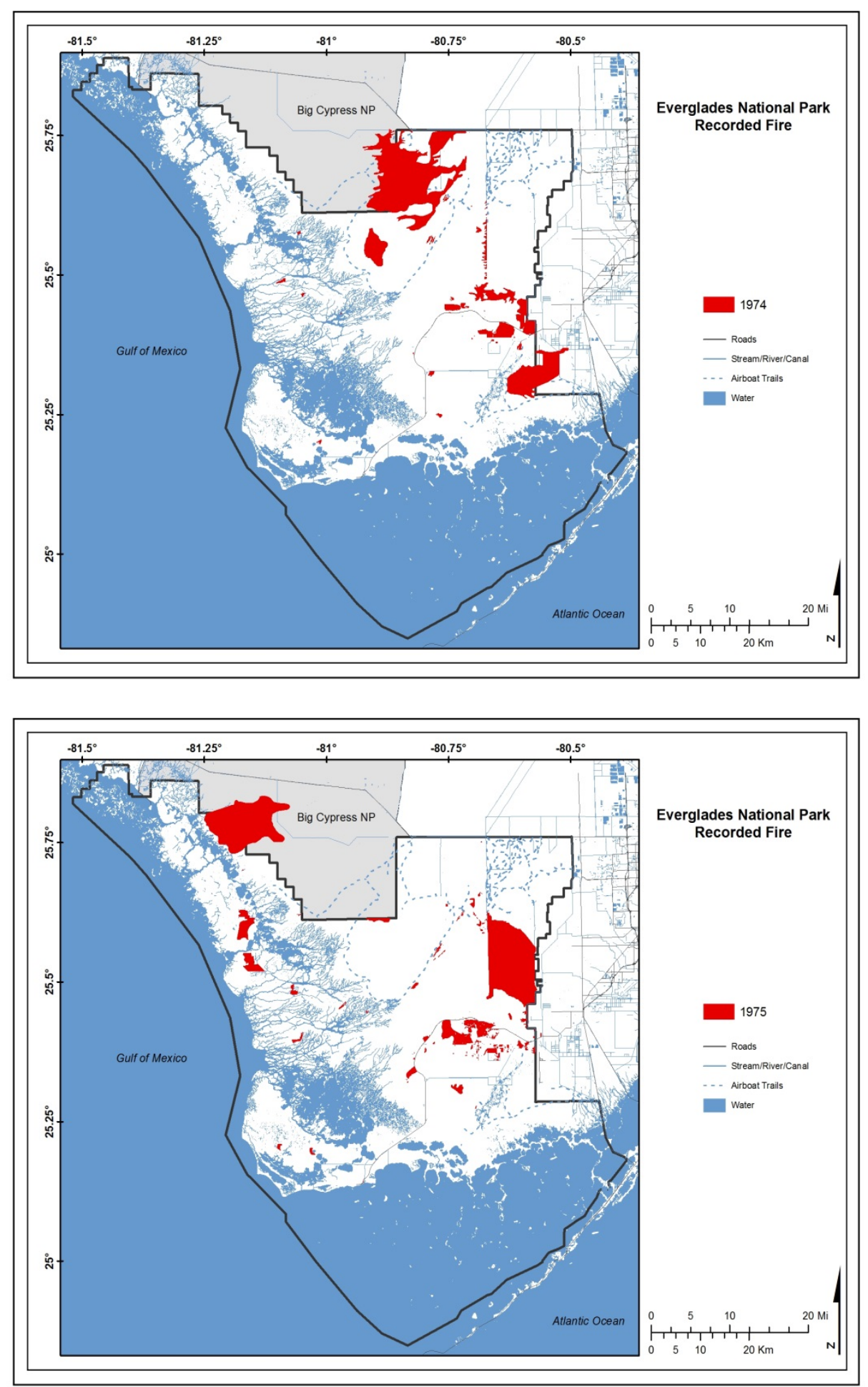

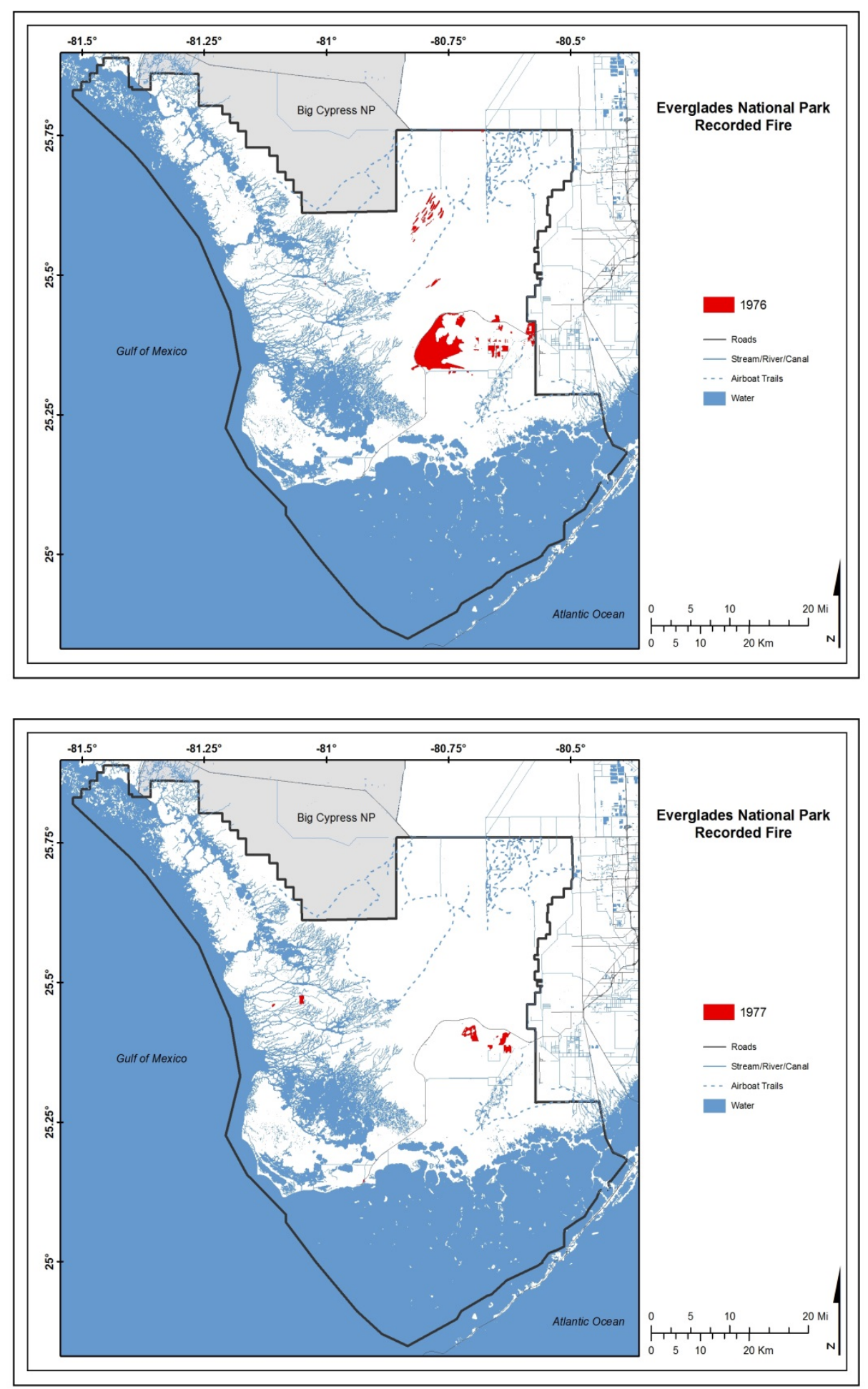

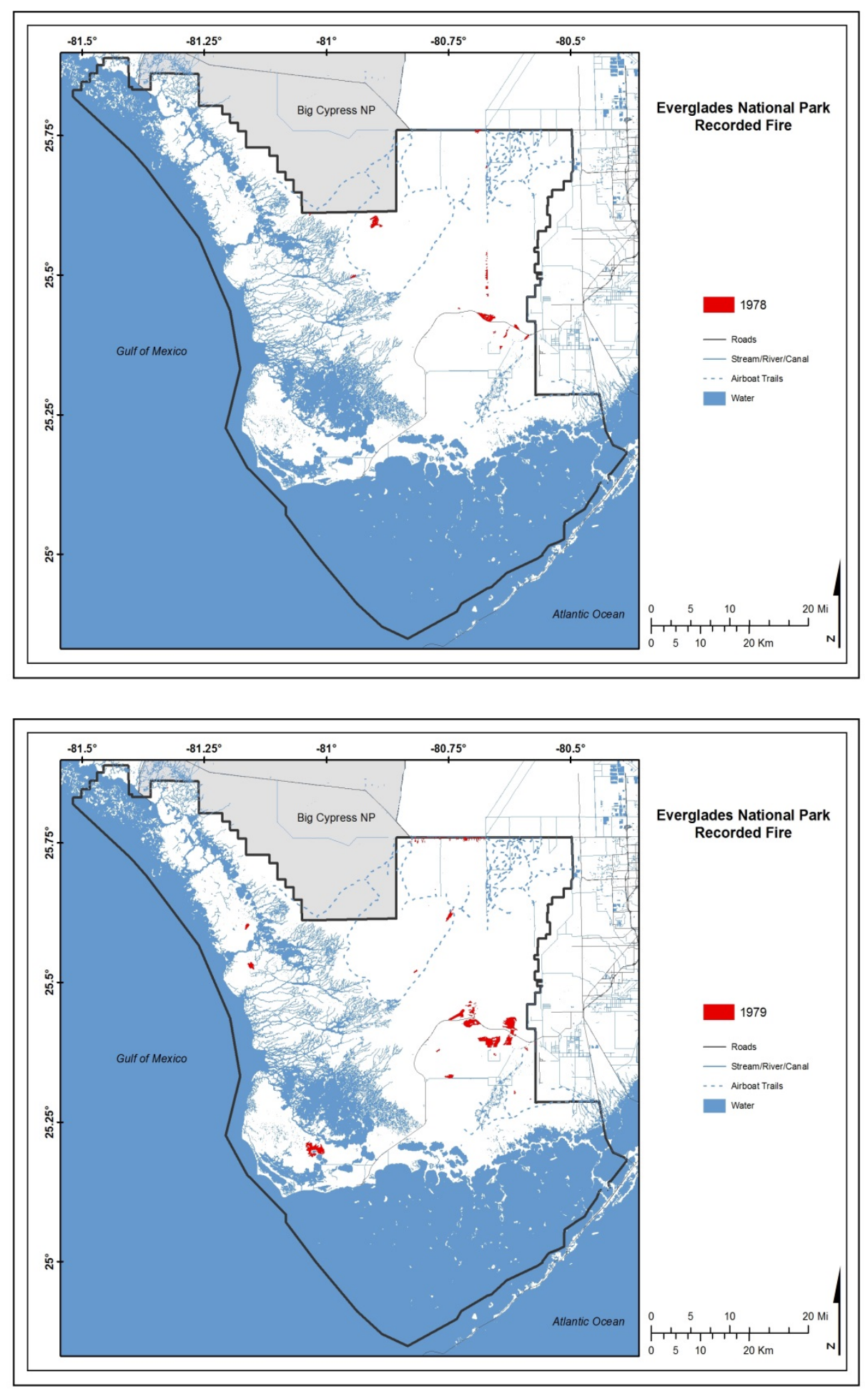

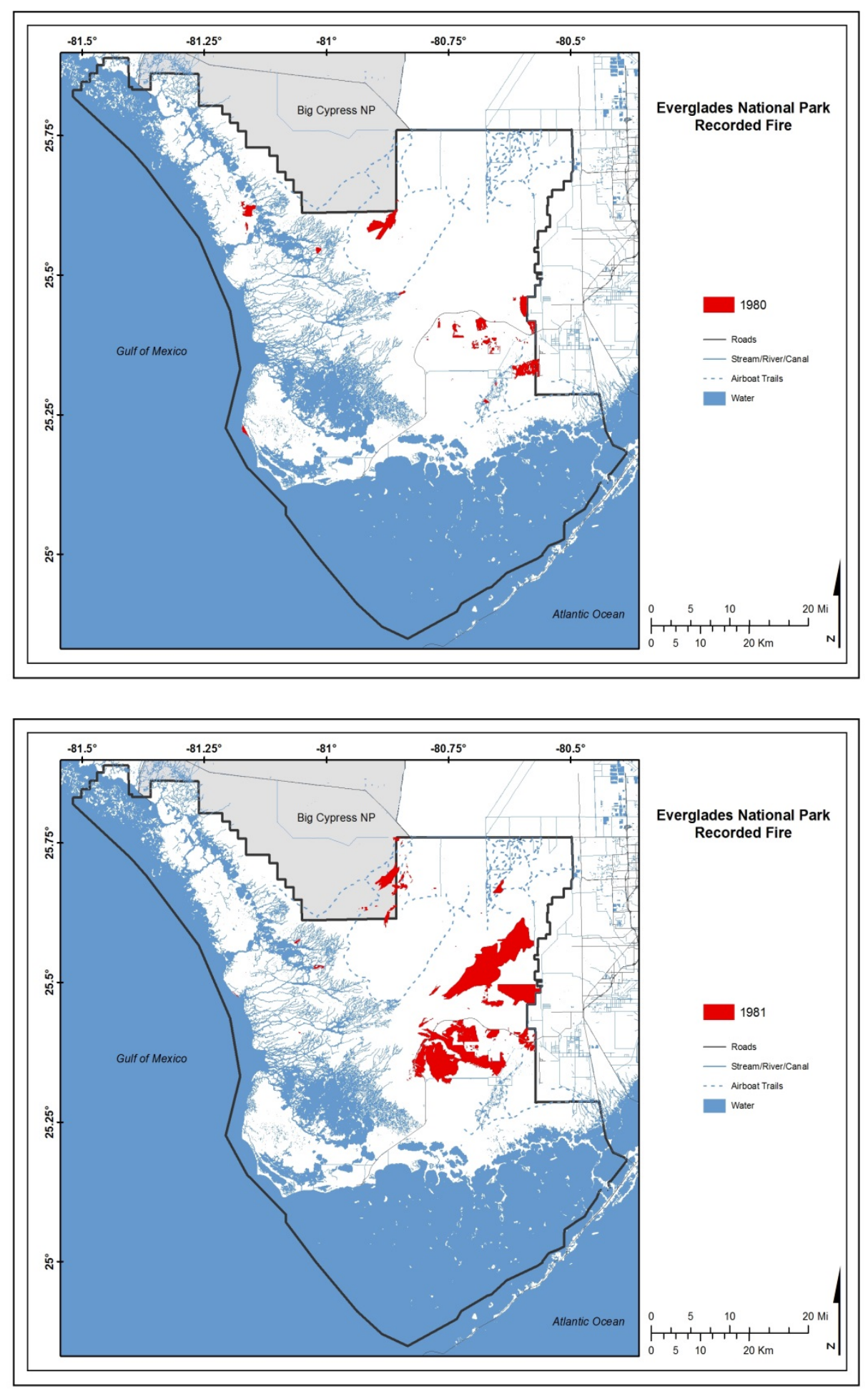

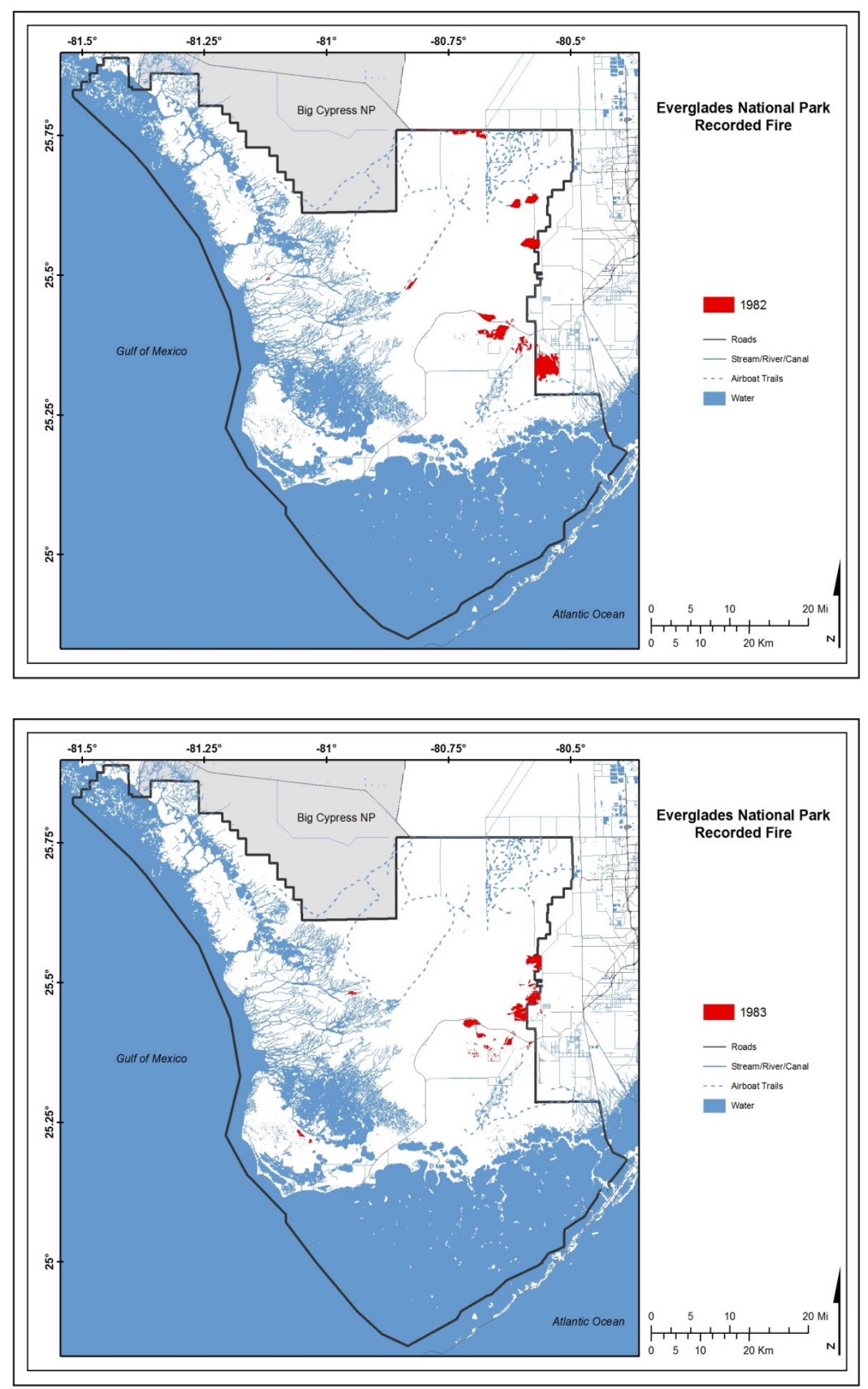

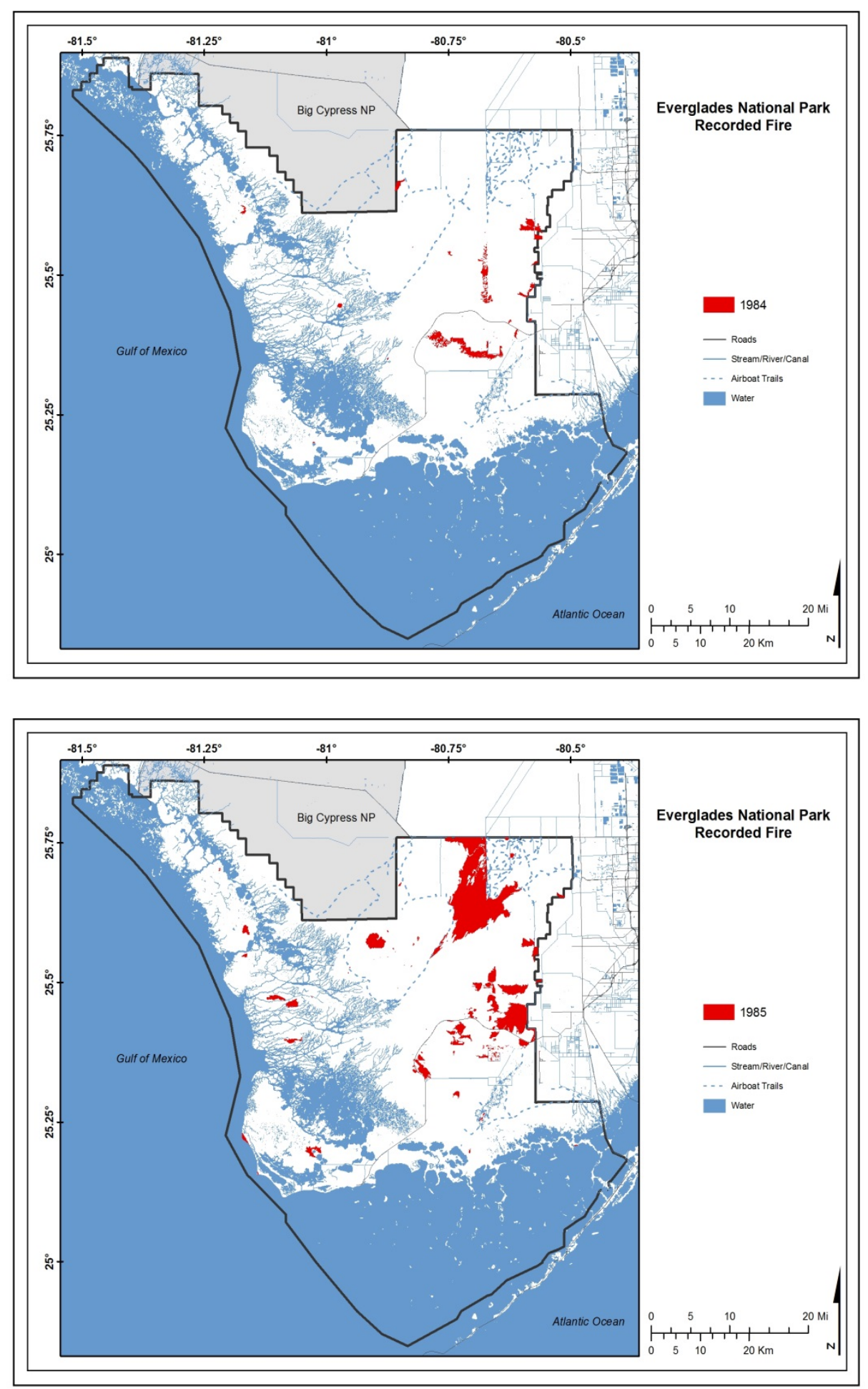

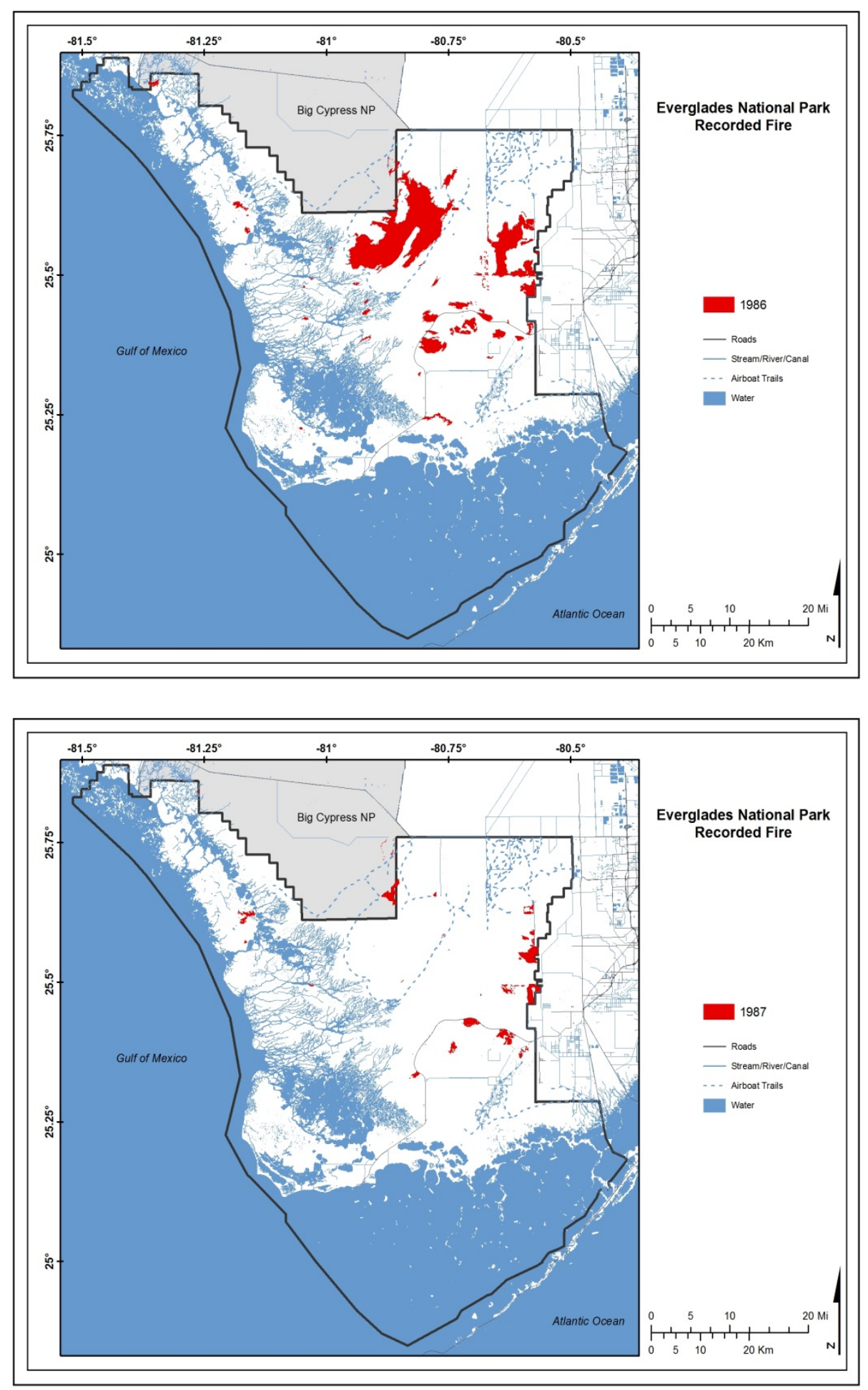

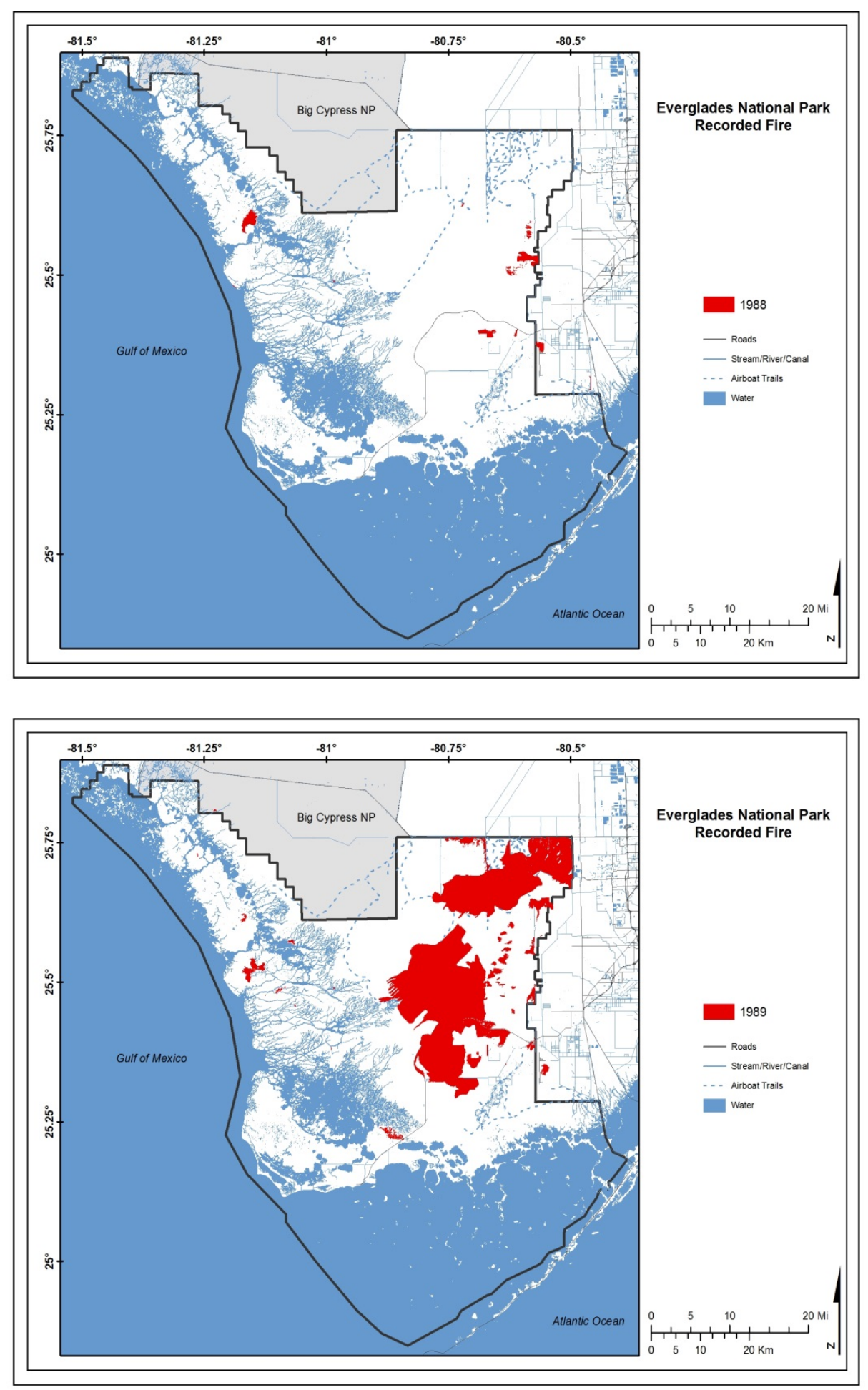

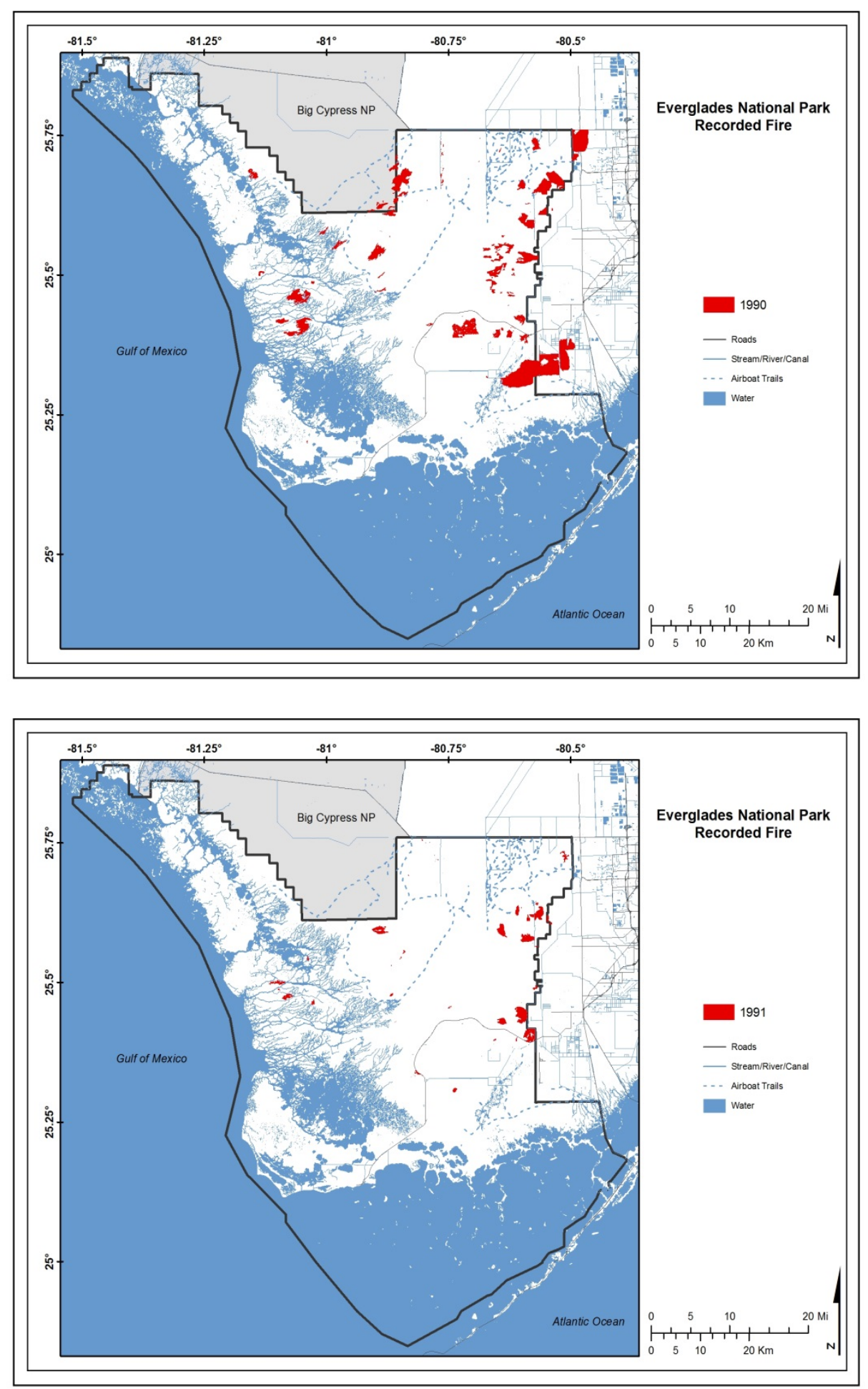

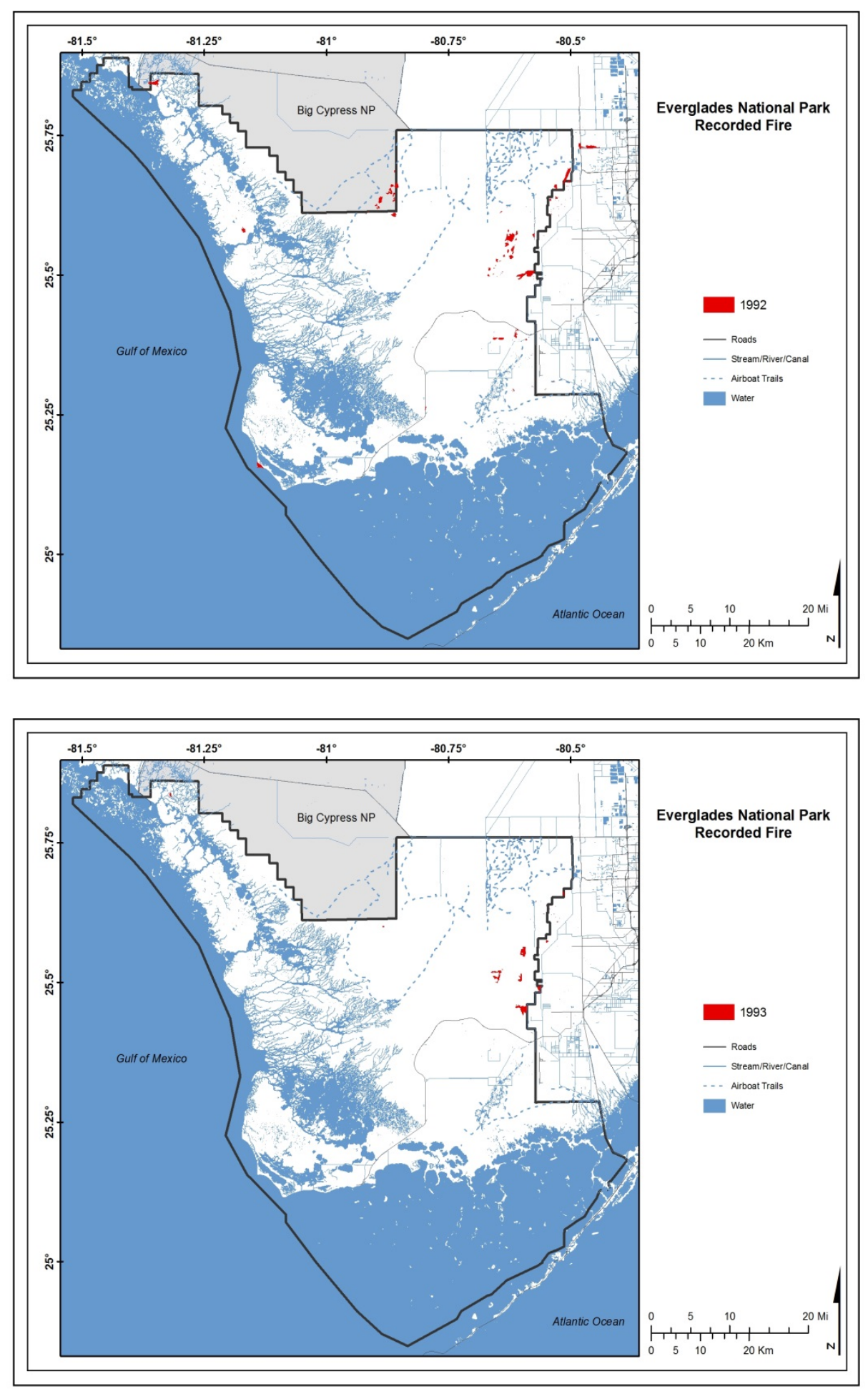

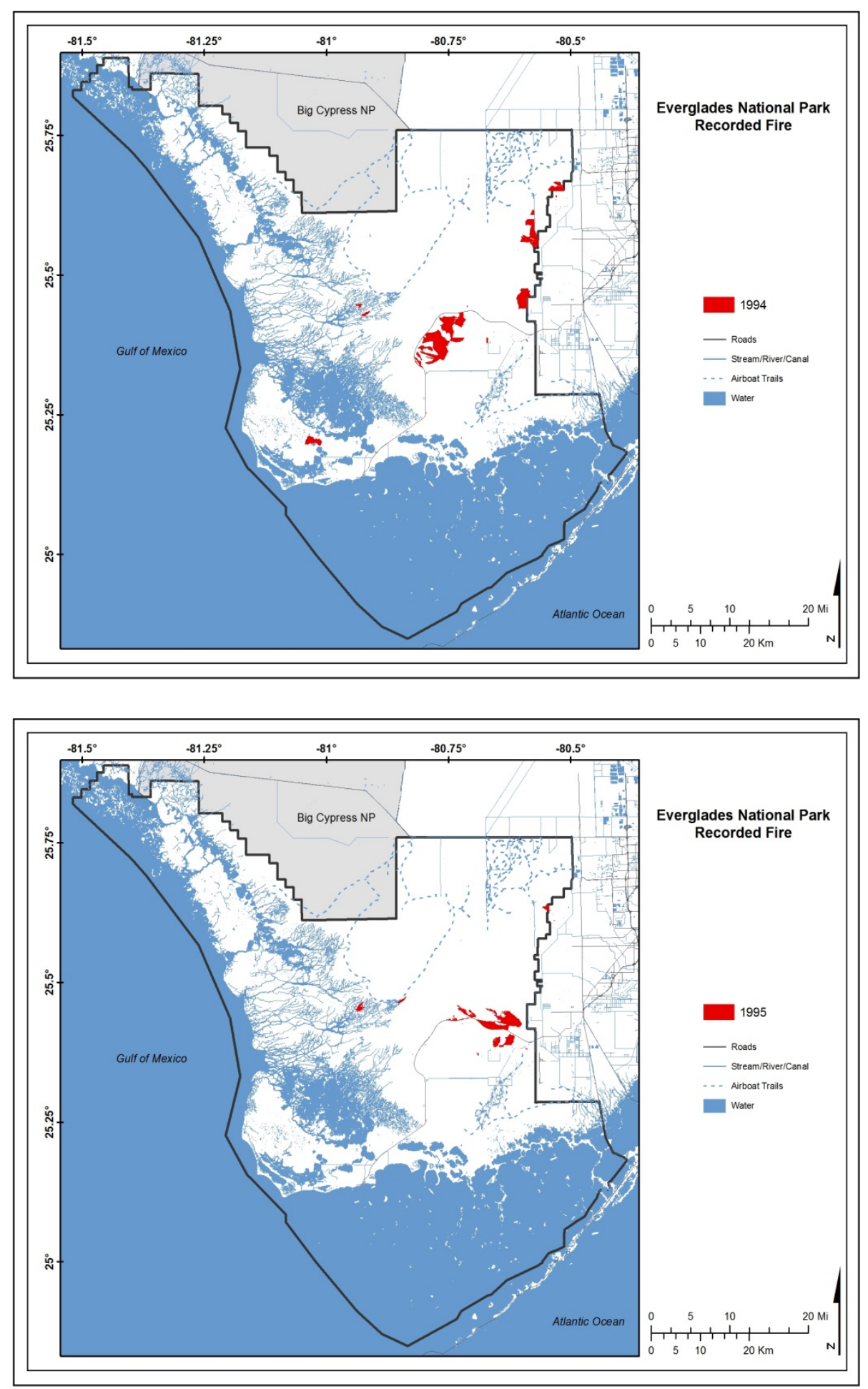

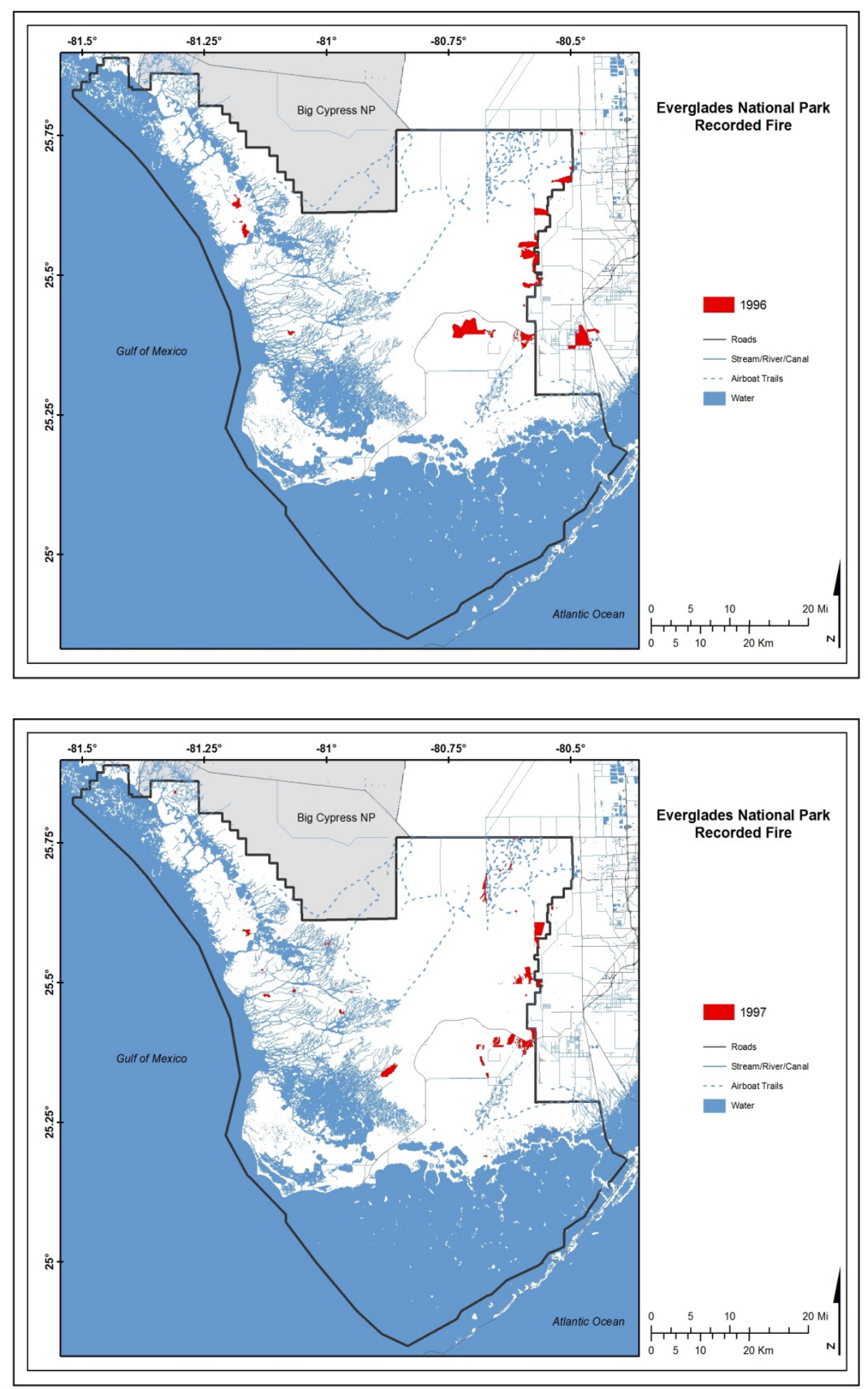

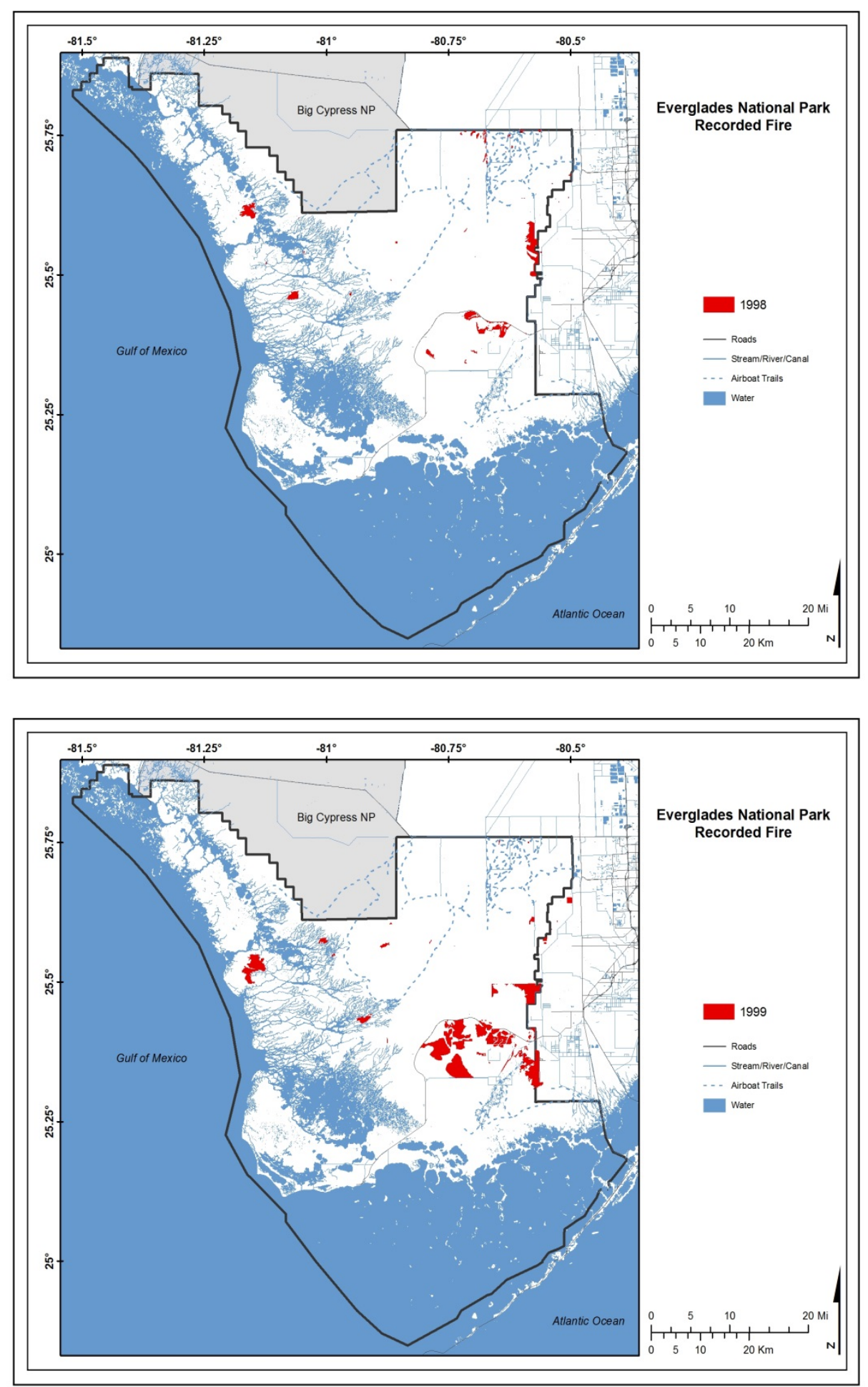

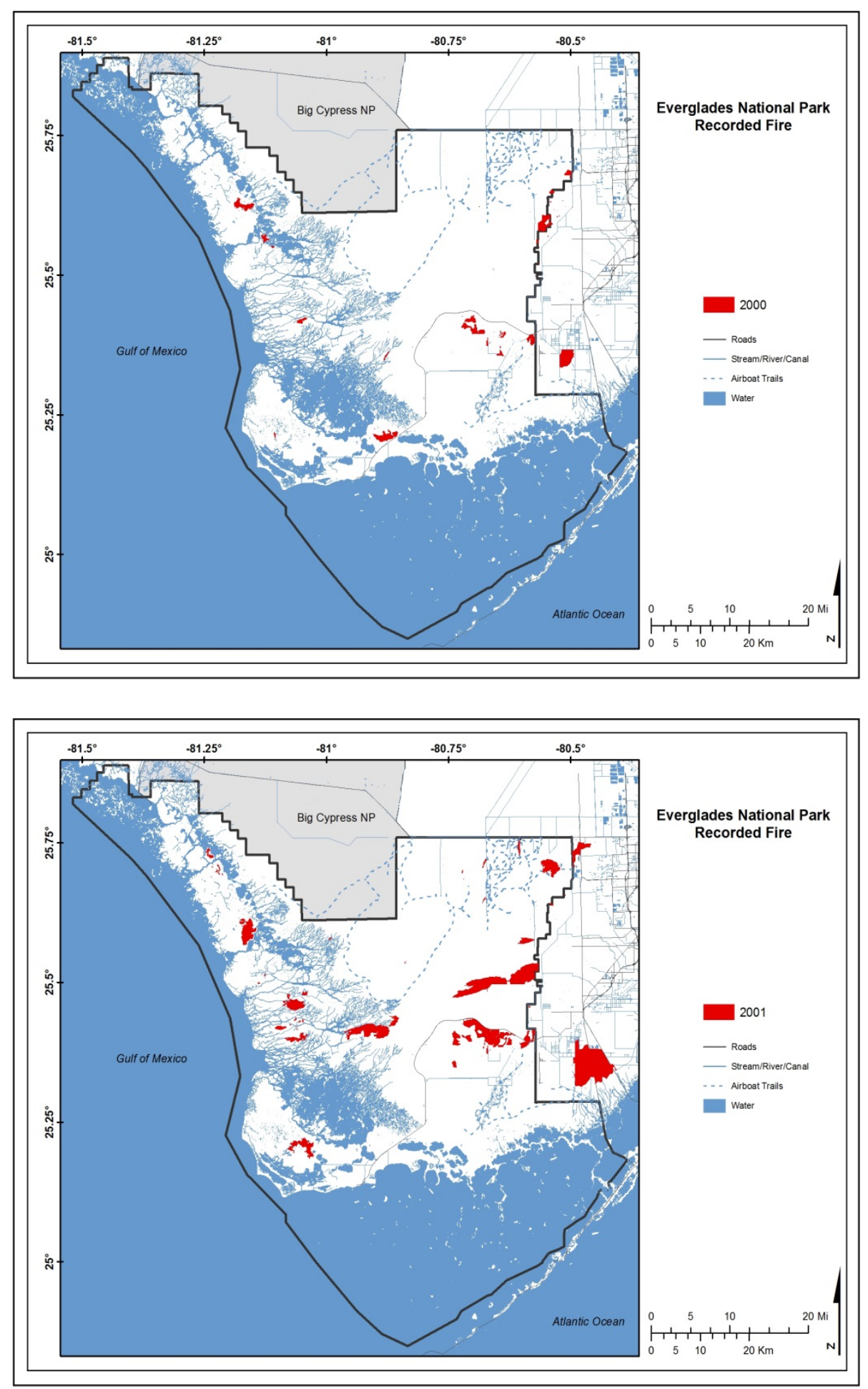

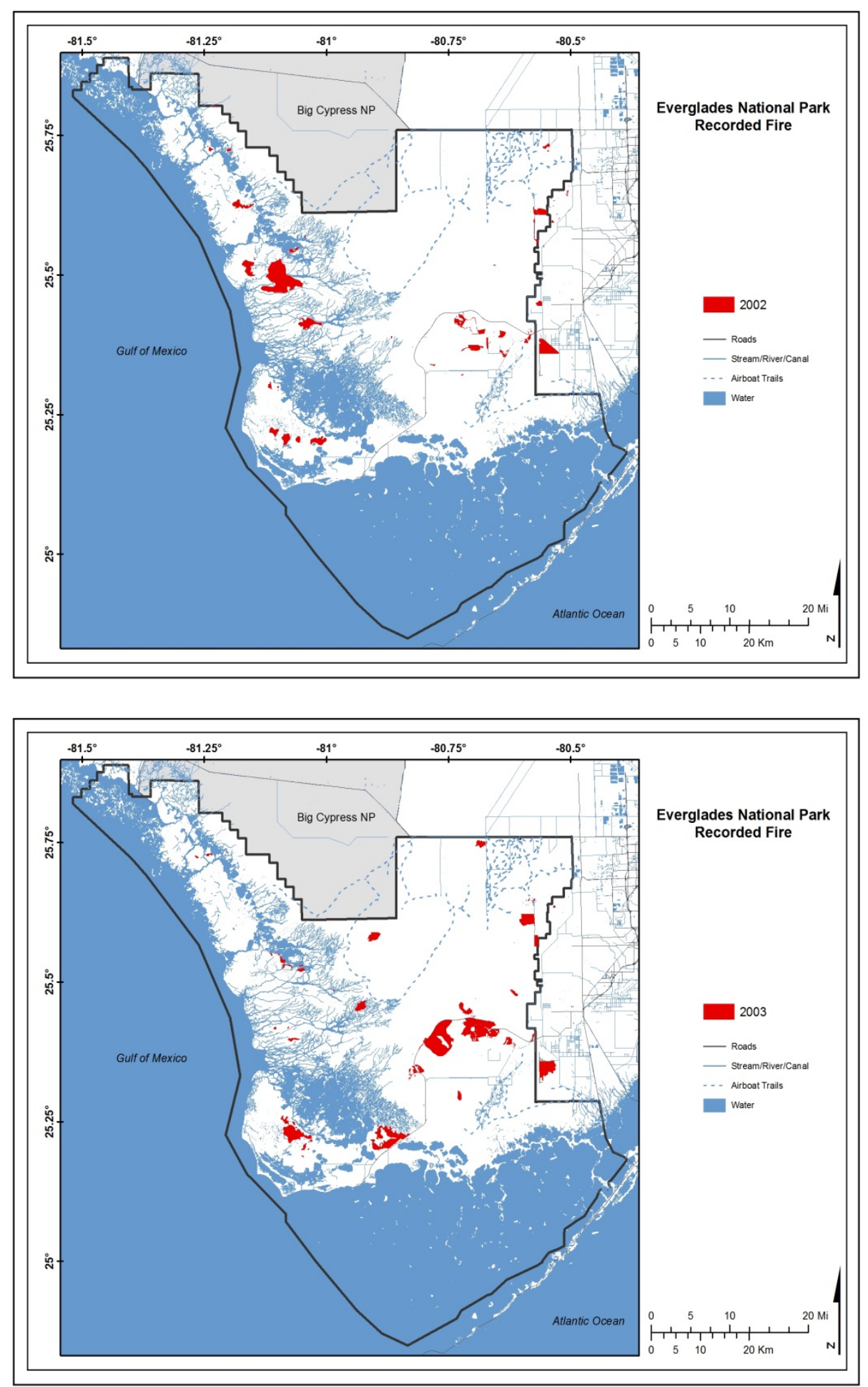

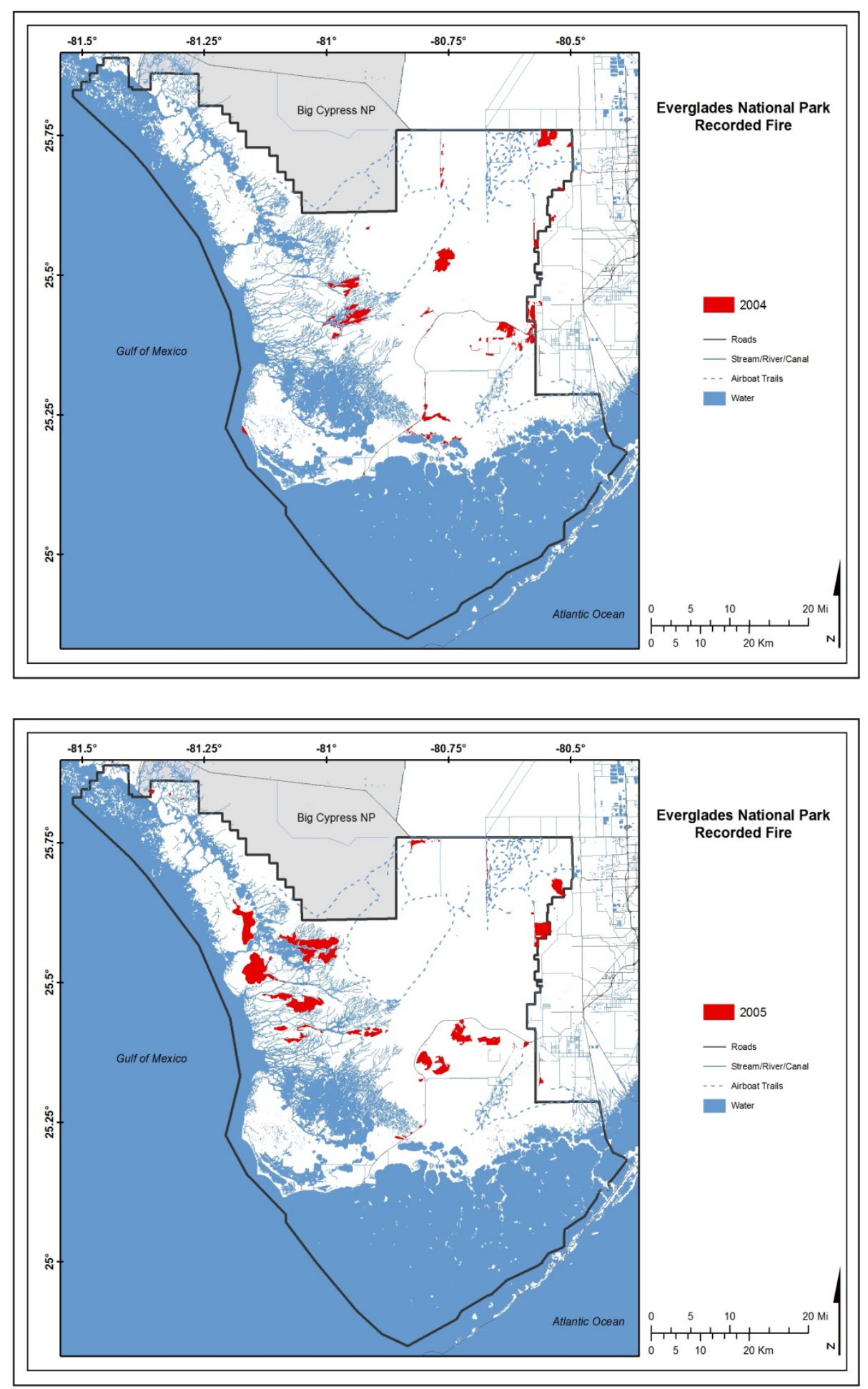

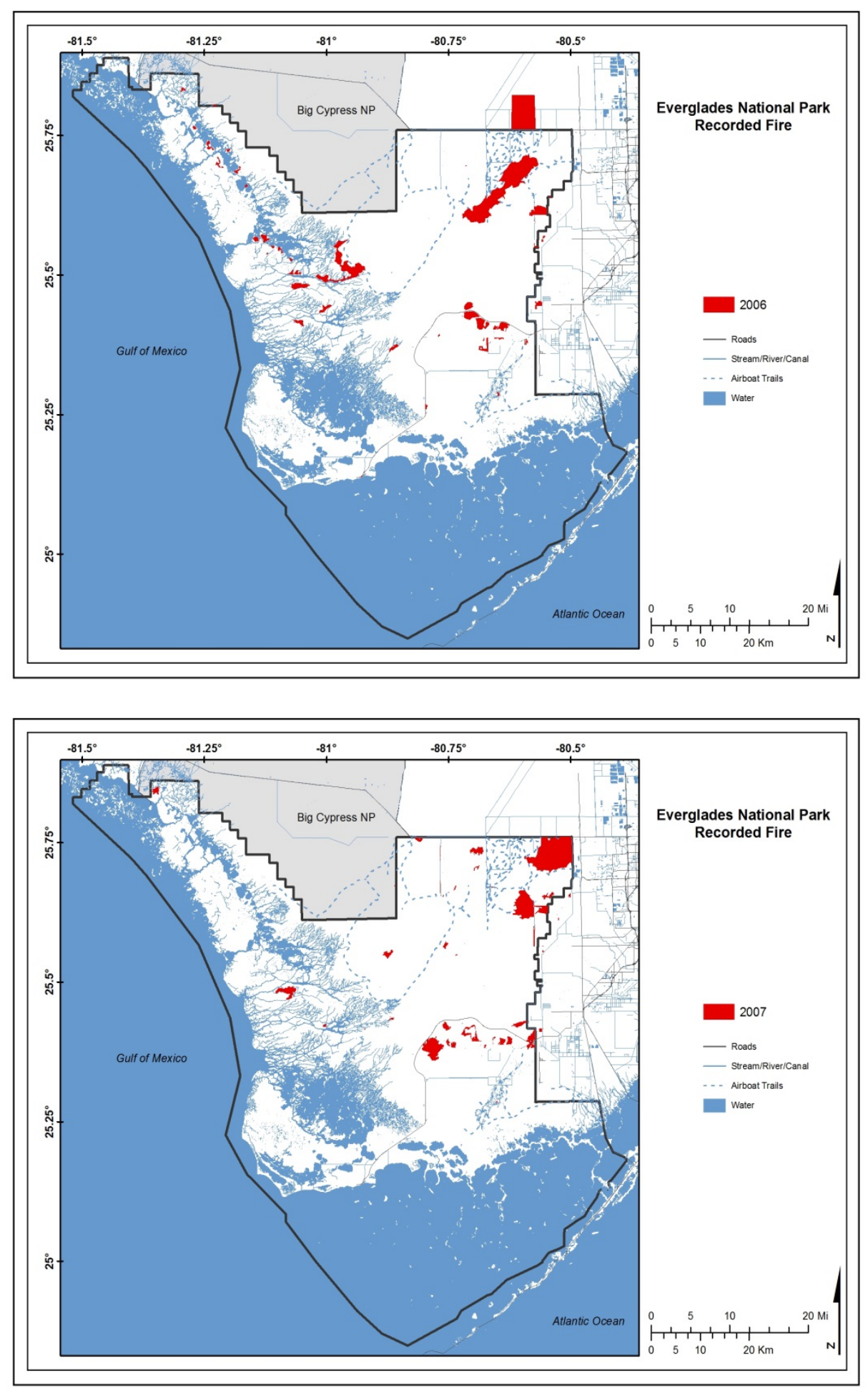

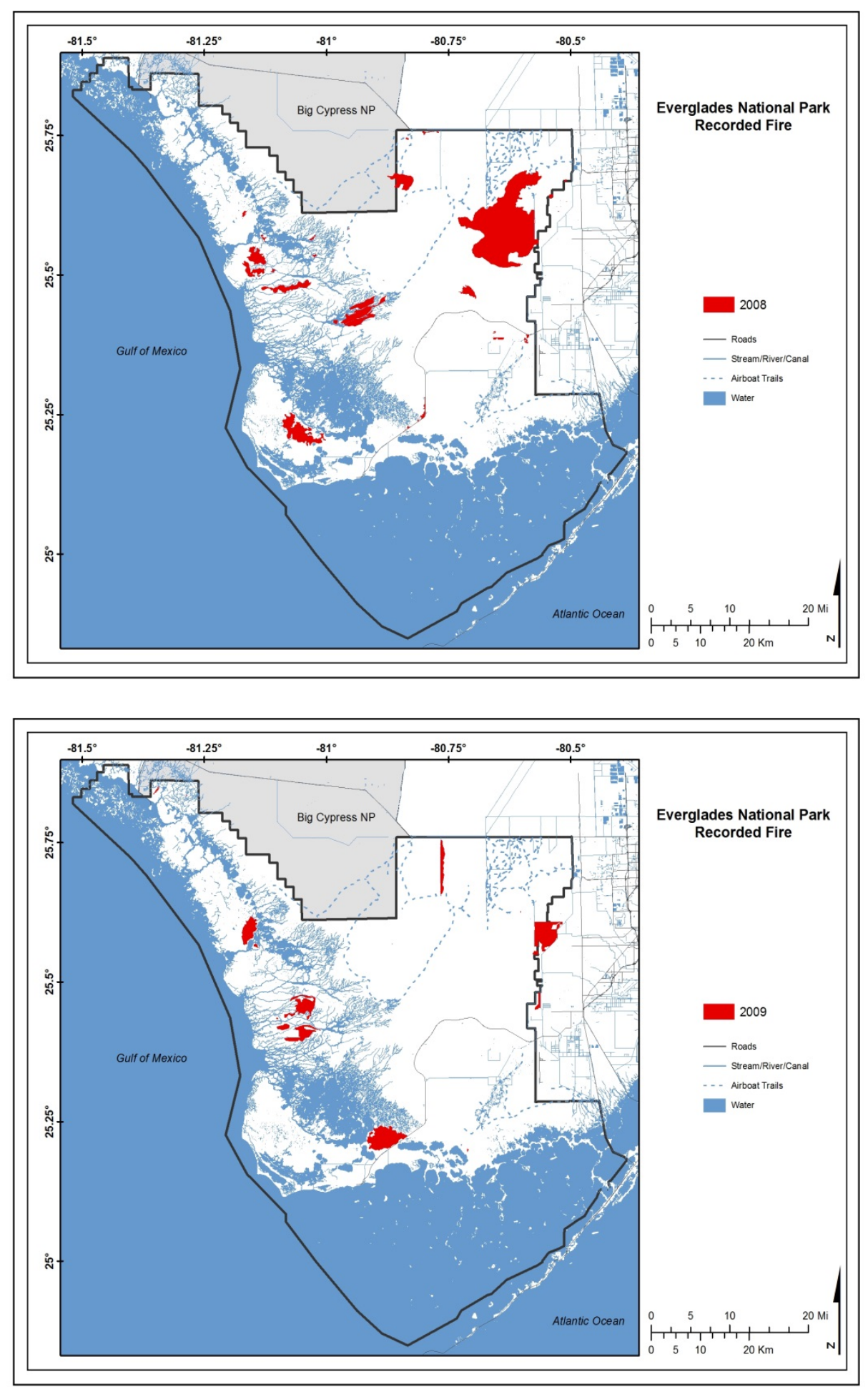


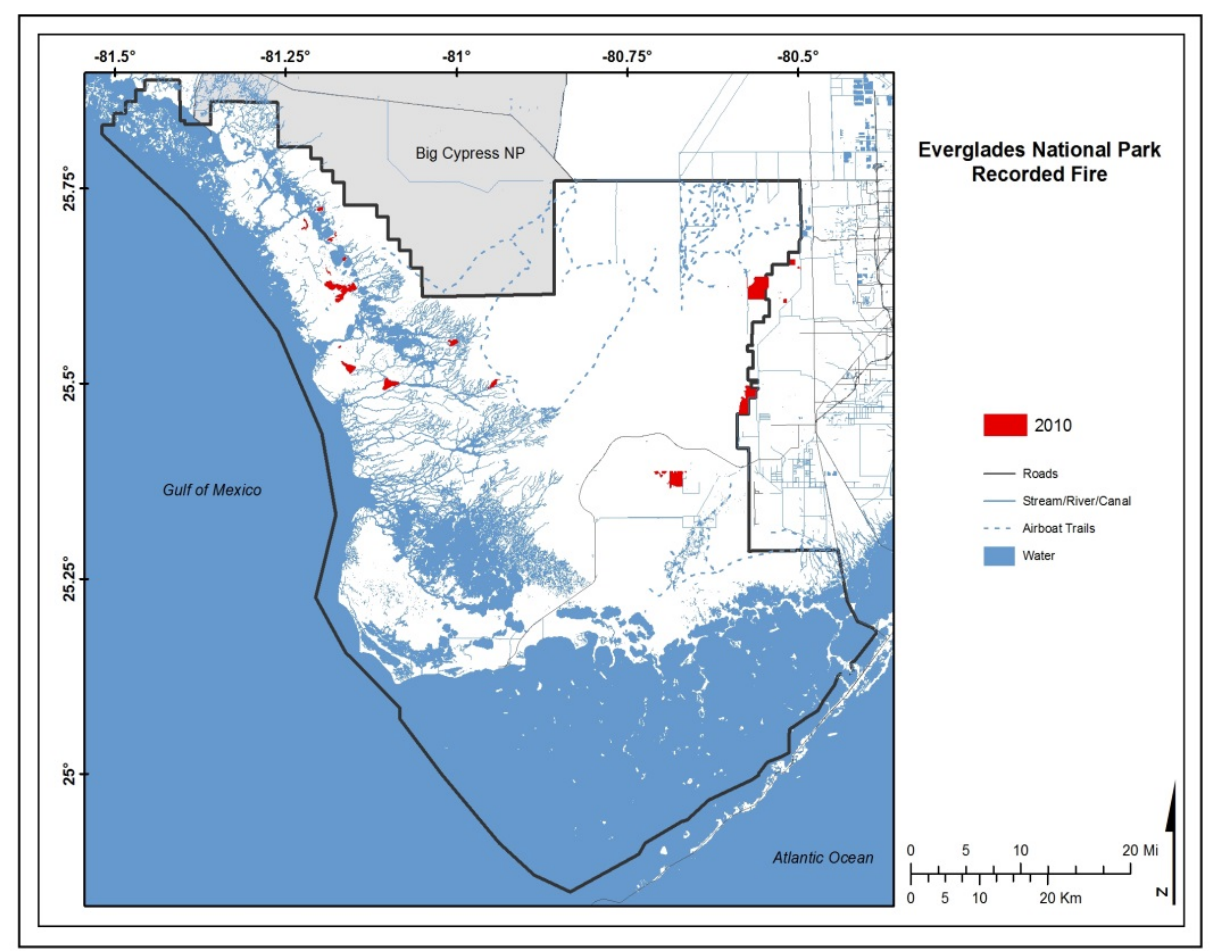




\section{Appendix B. Maps of Fires in Big Cypress National Preserve by Year}
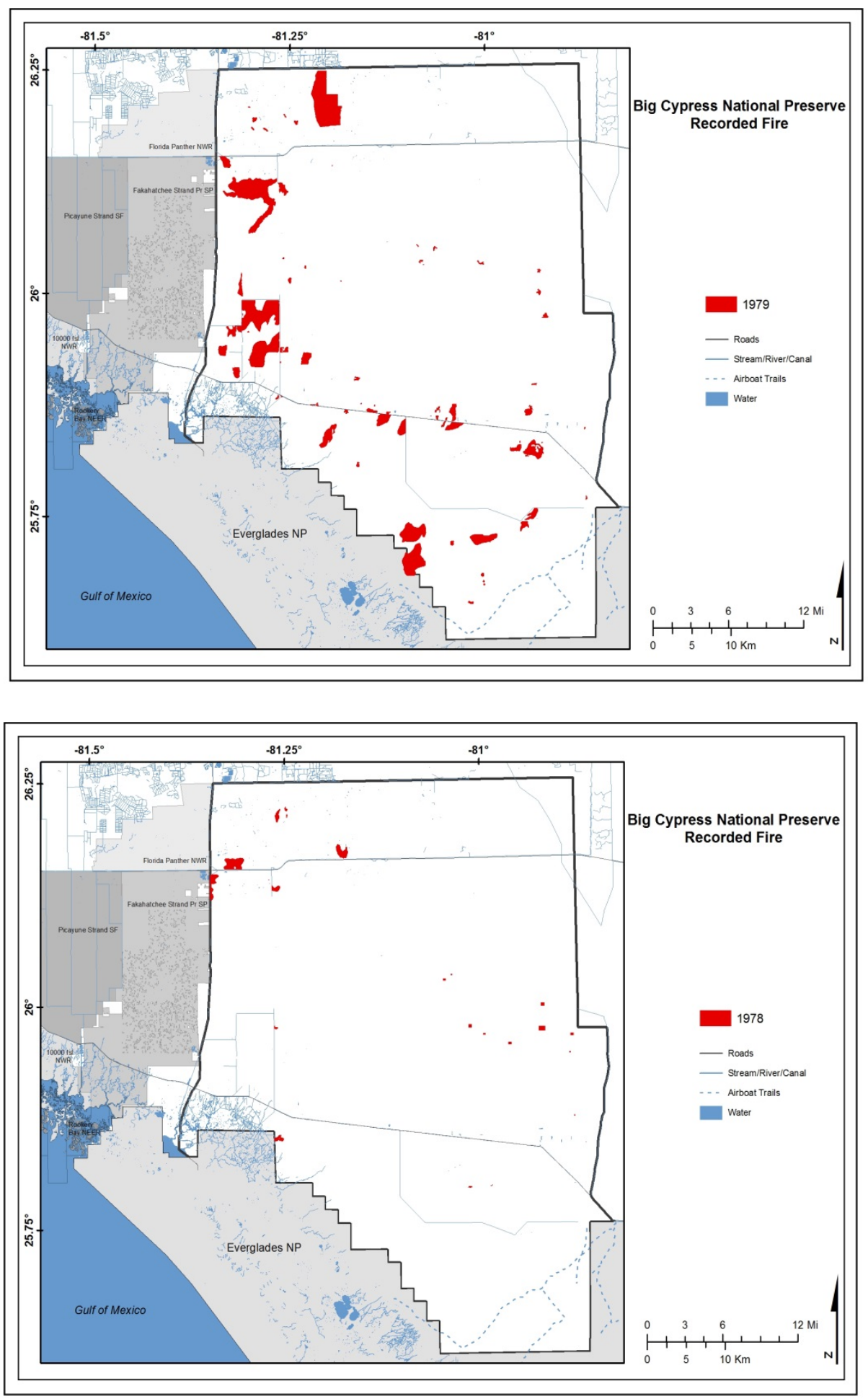

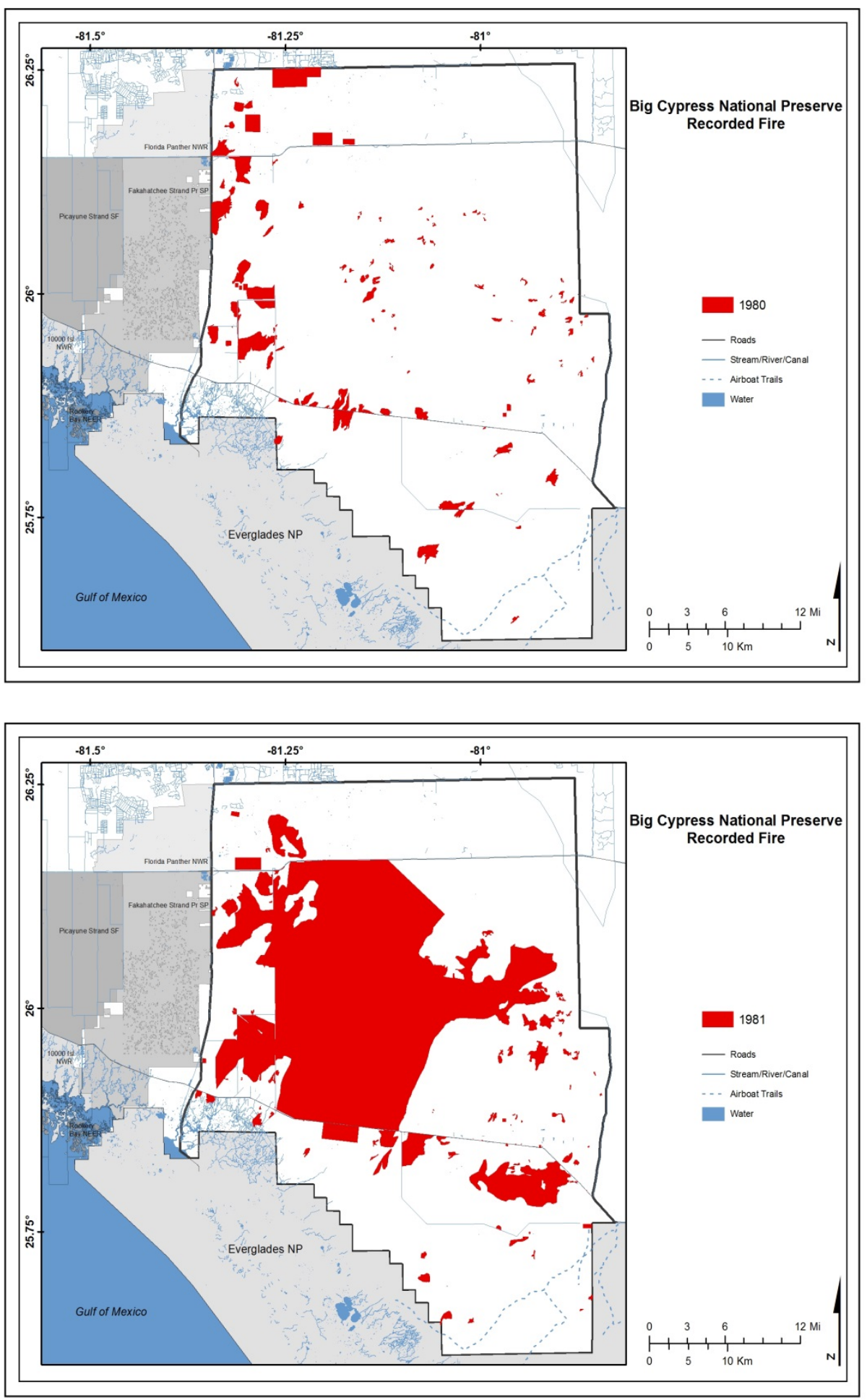

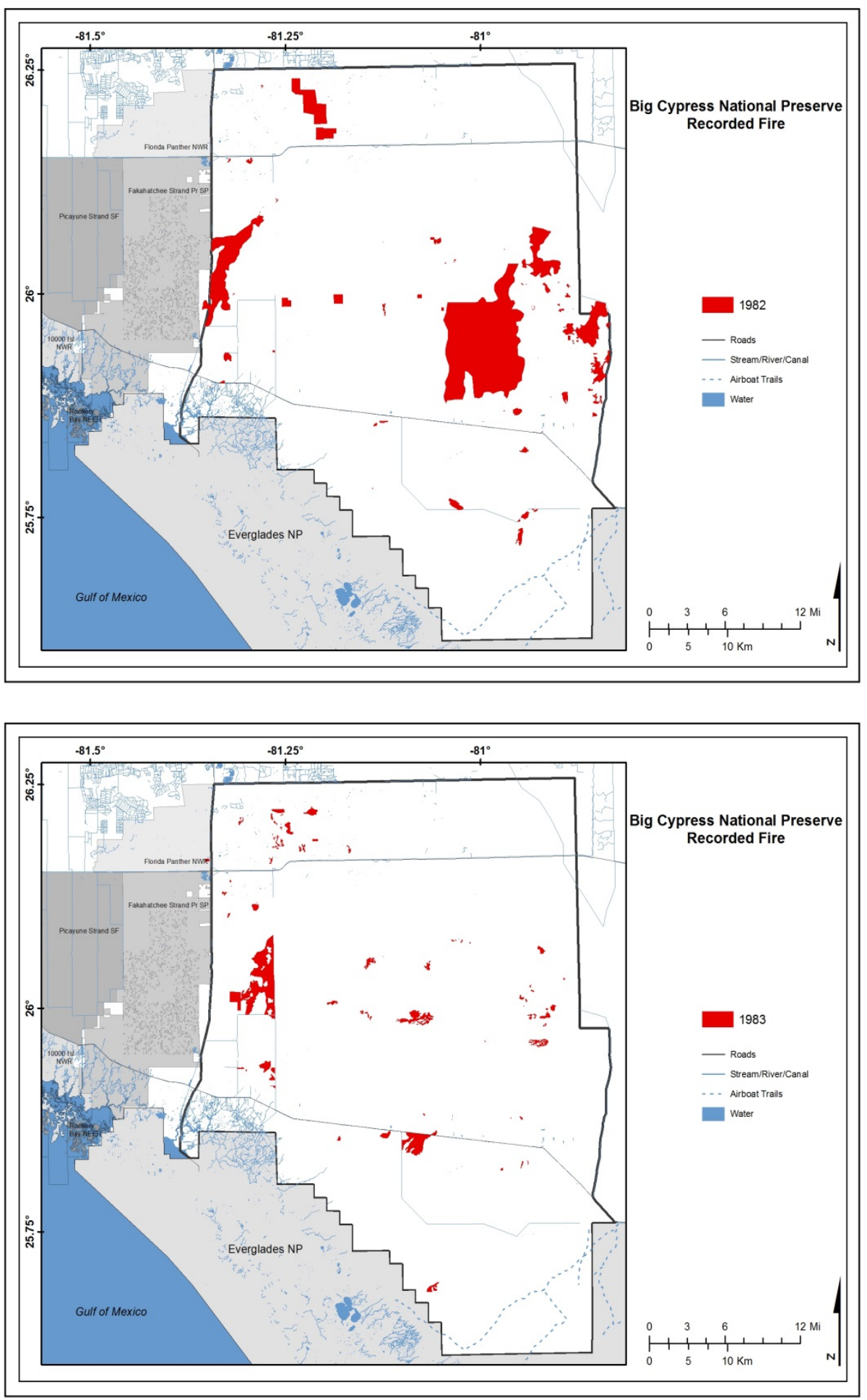

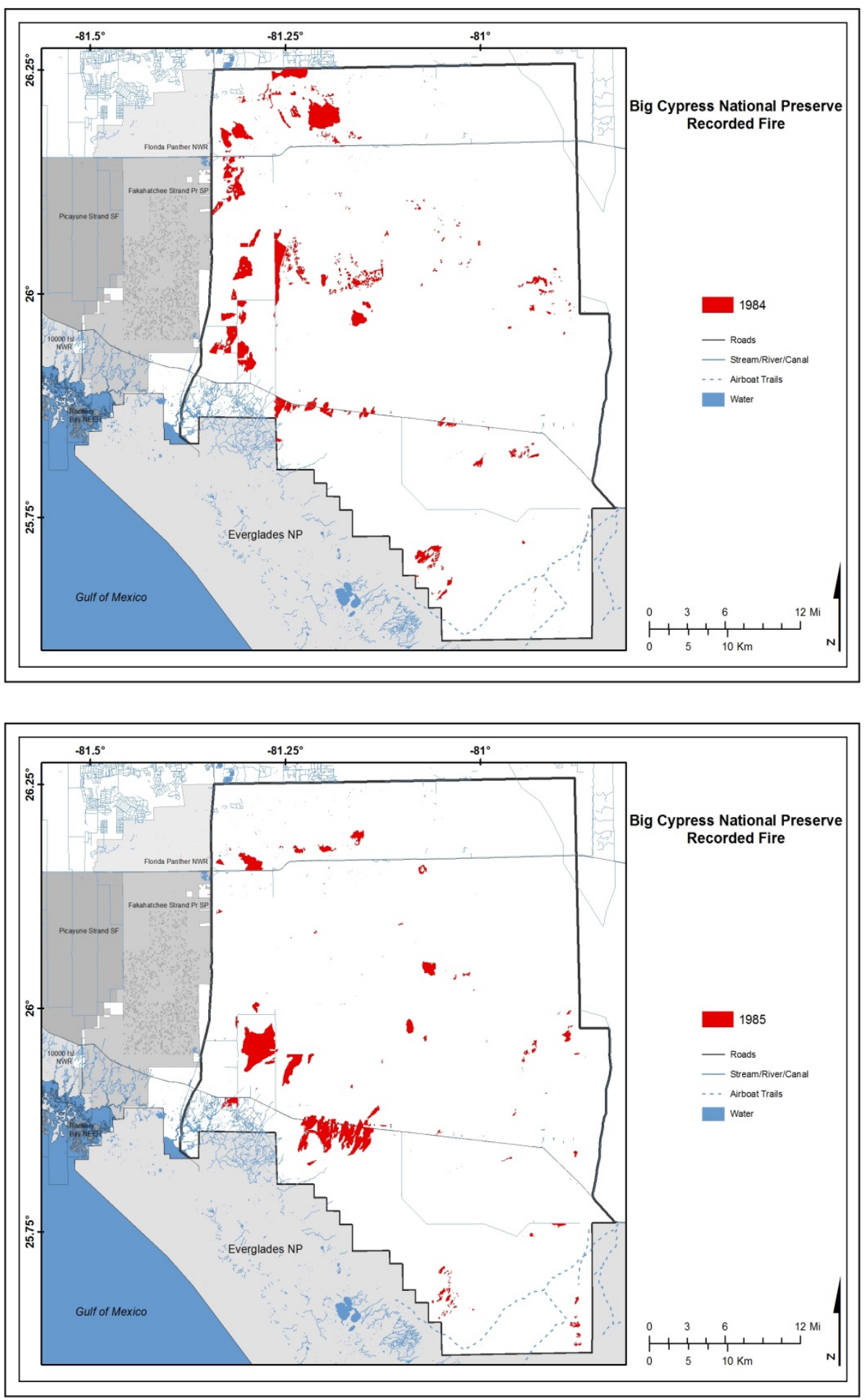

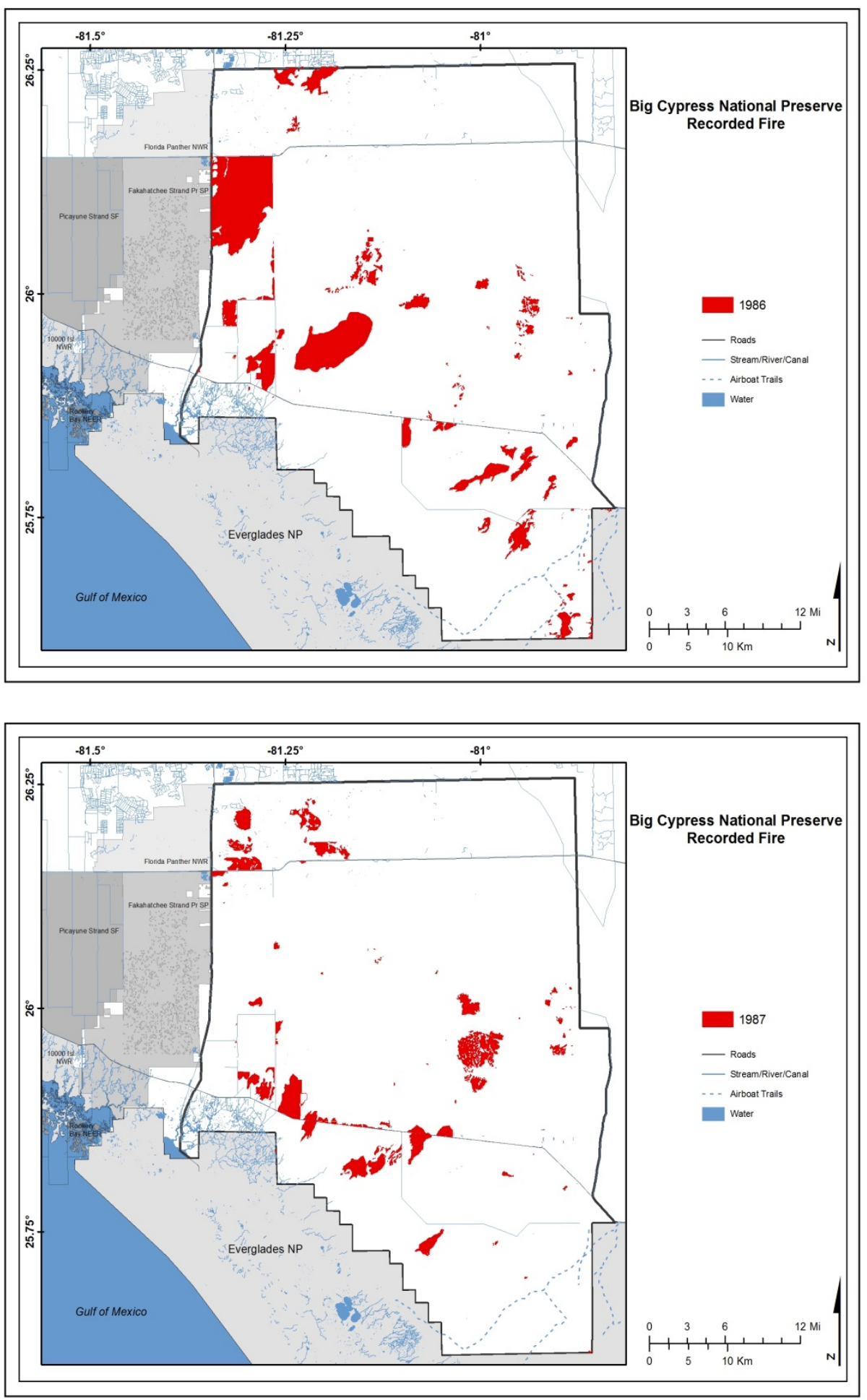

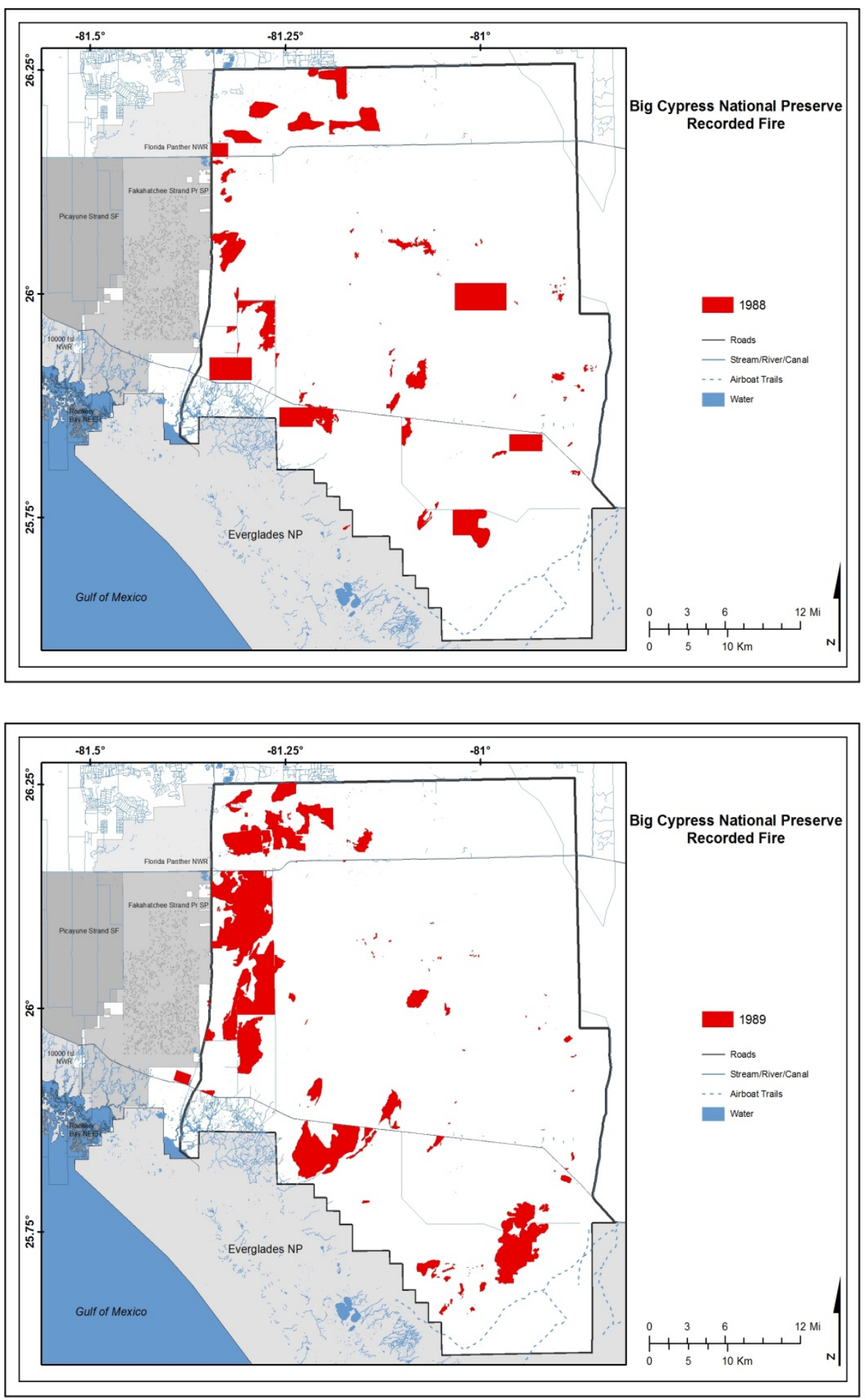

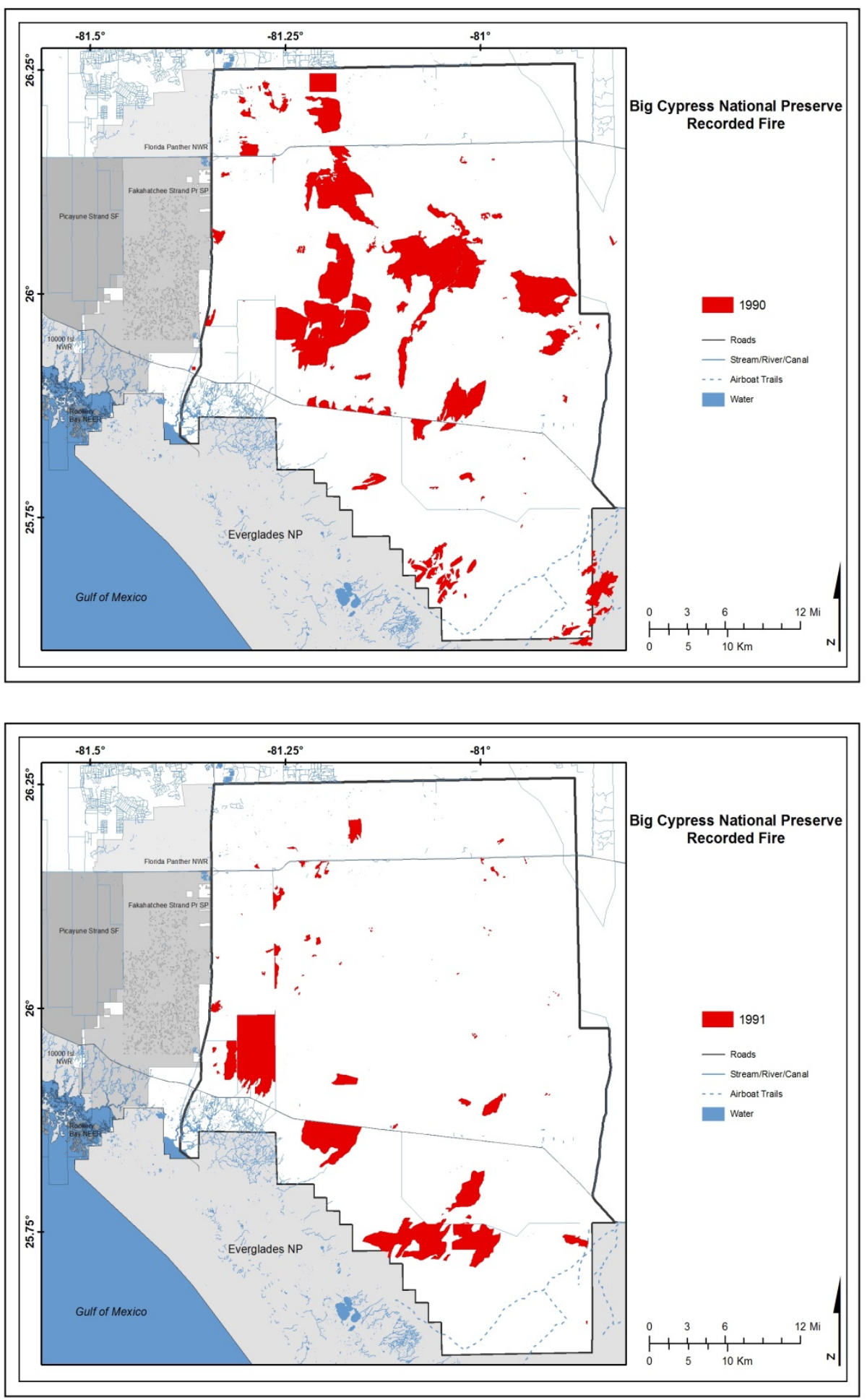

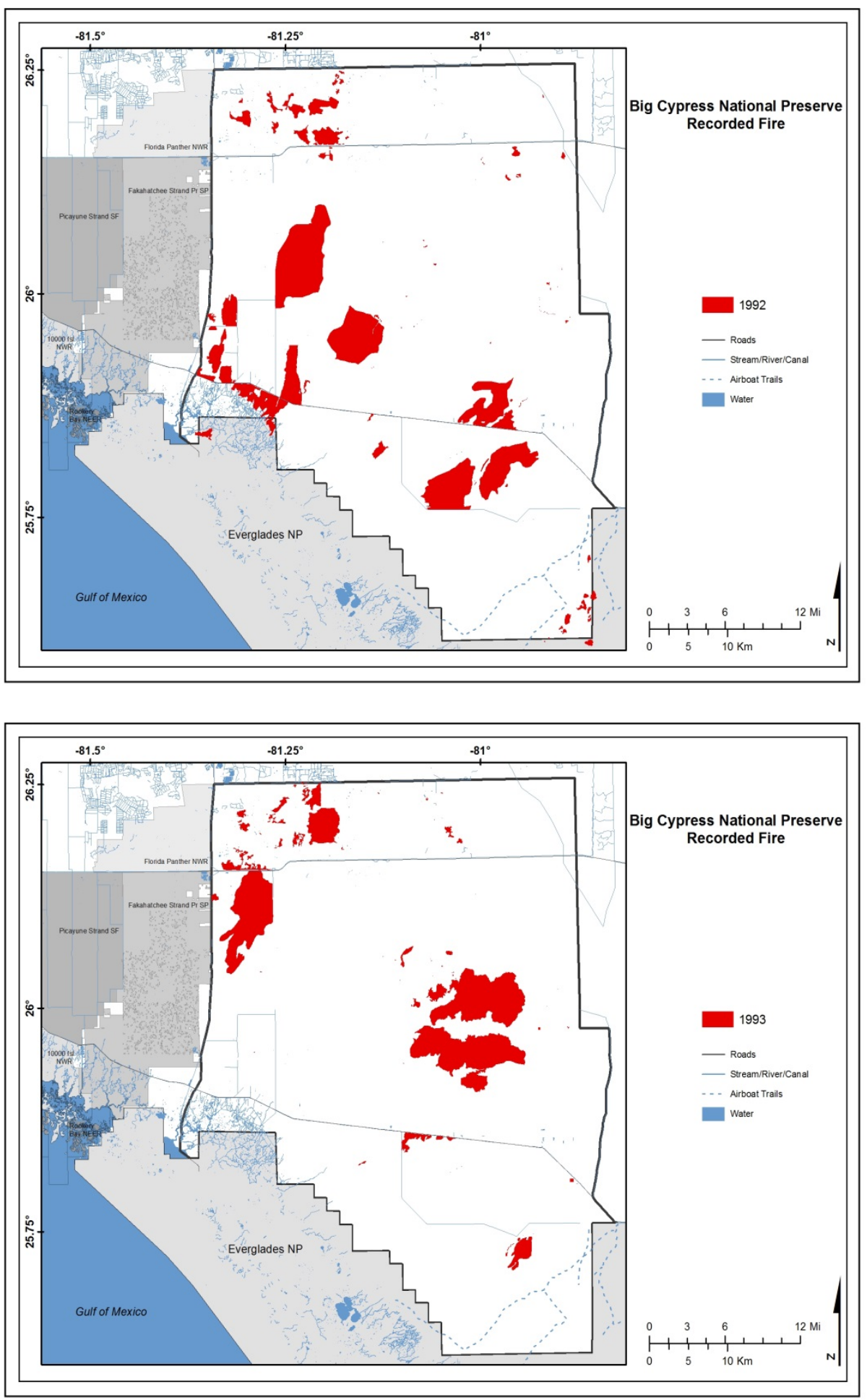

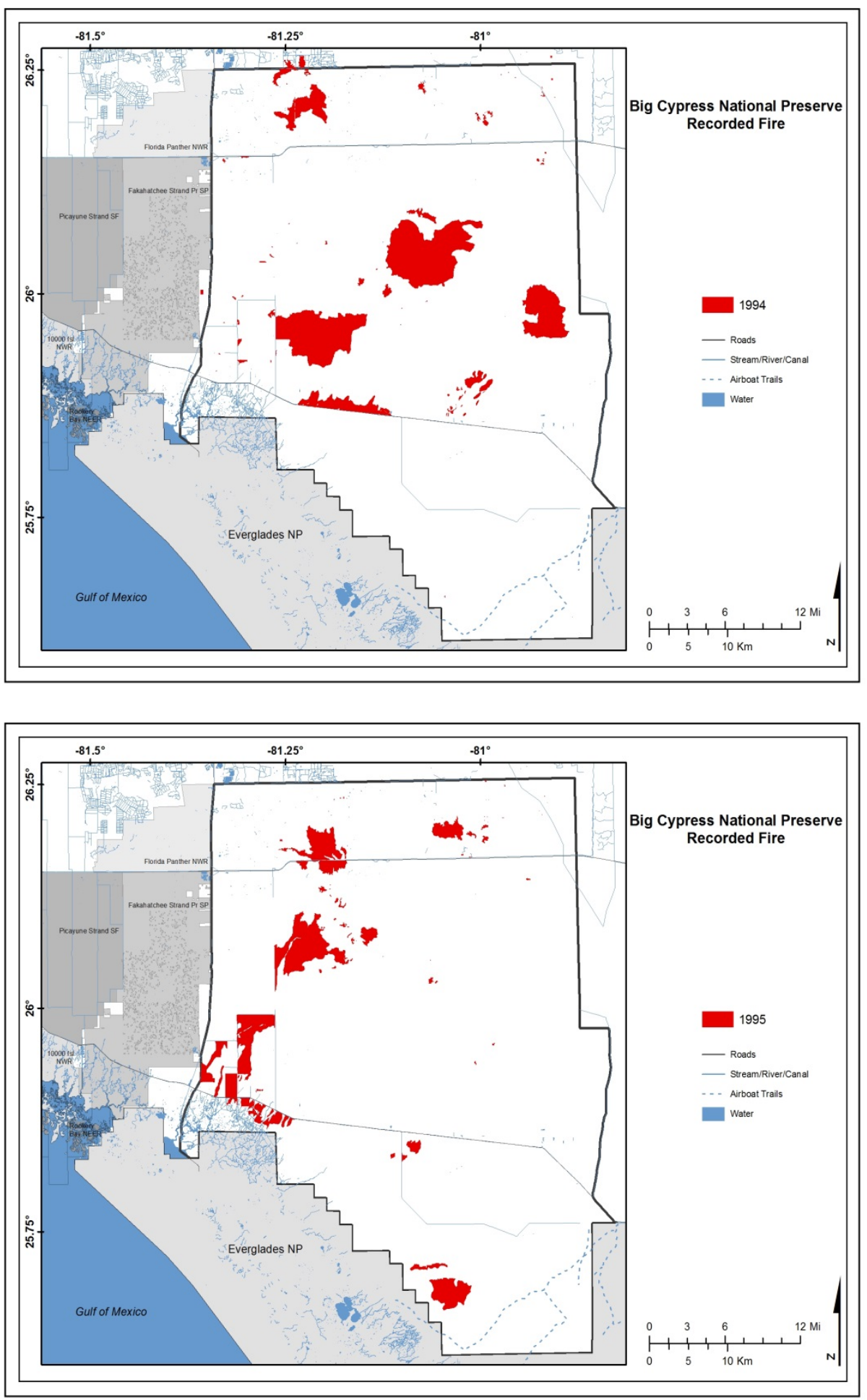

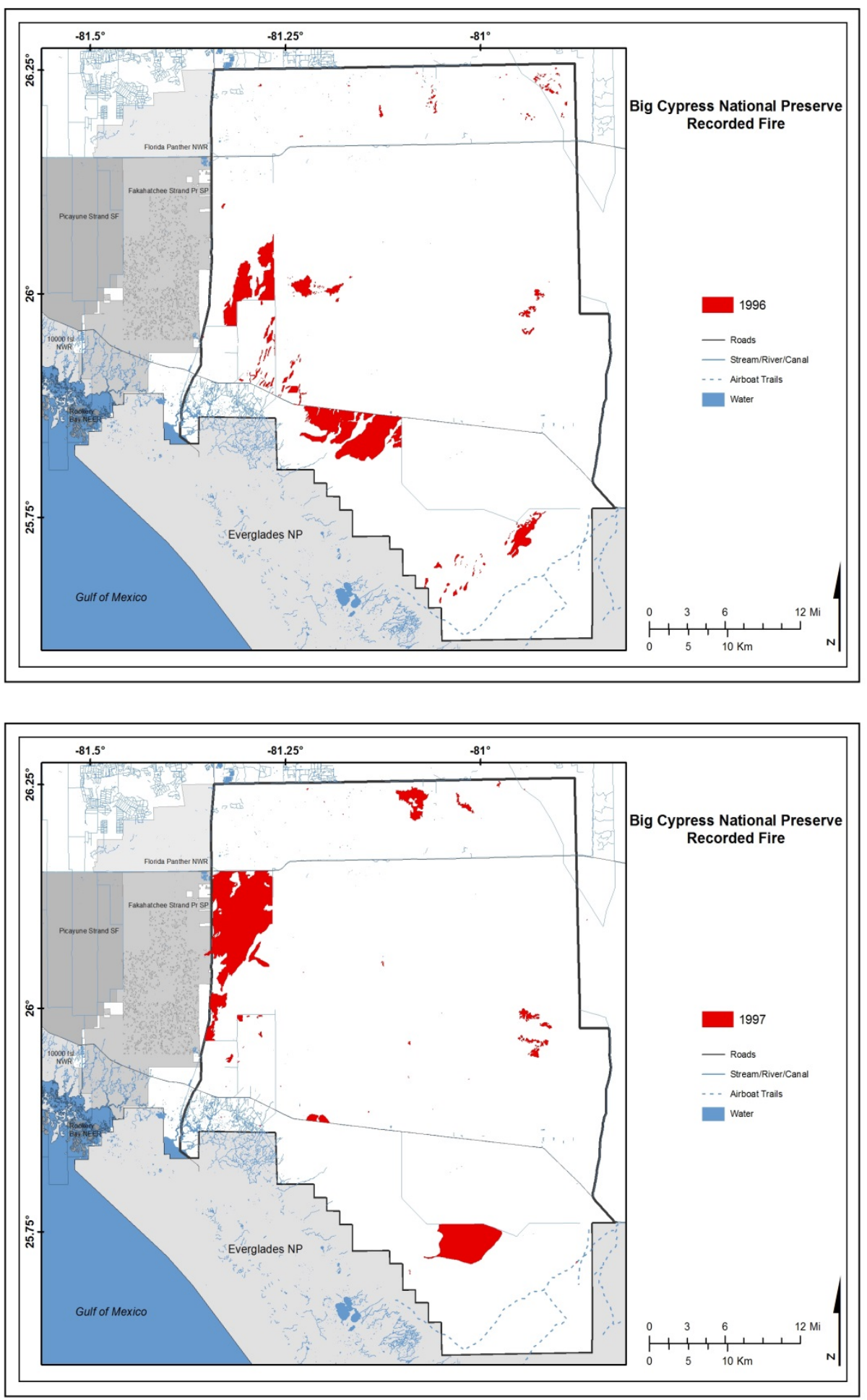

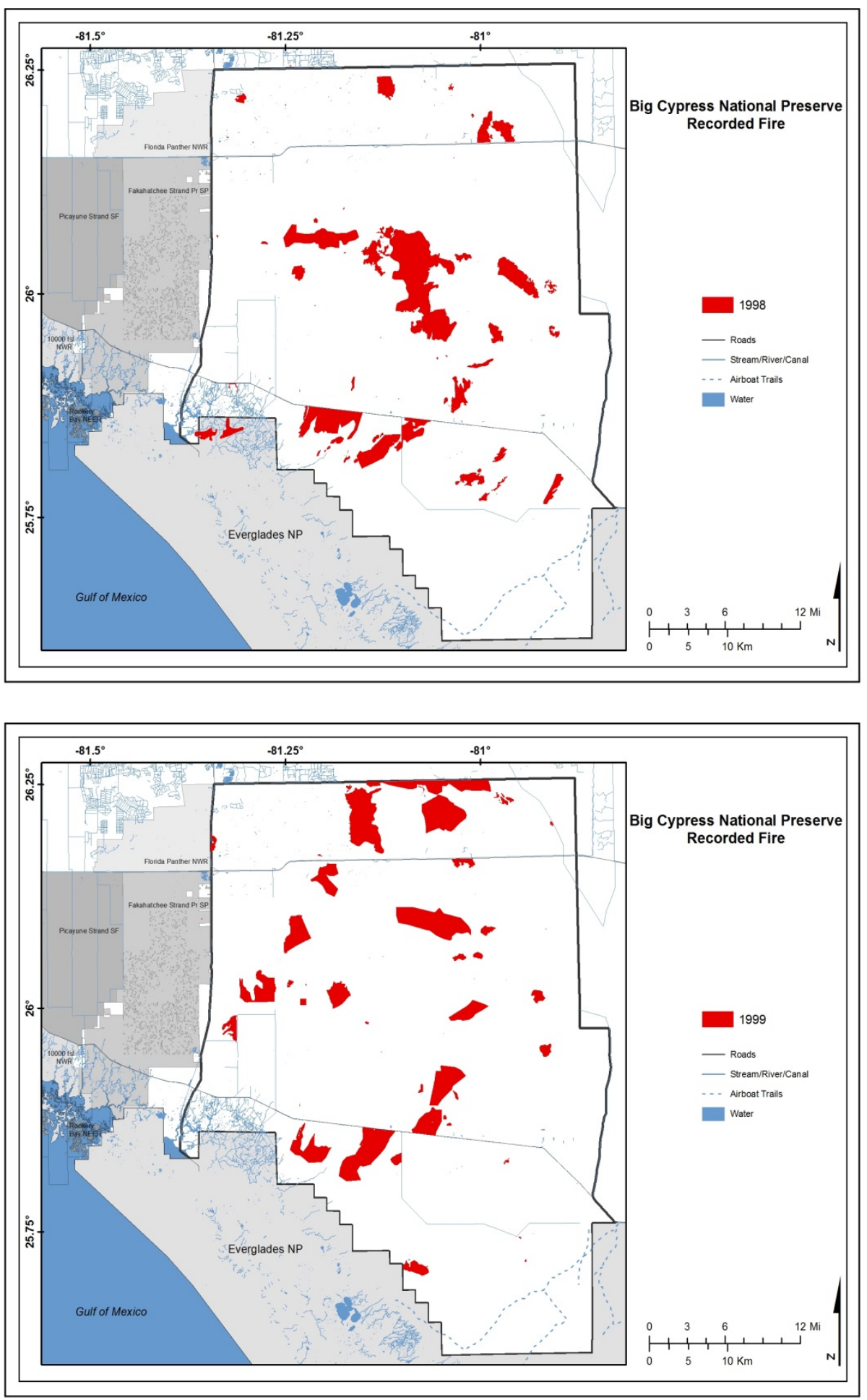

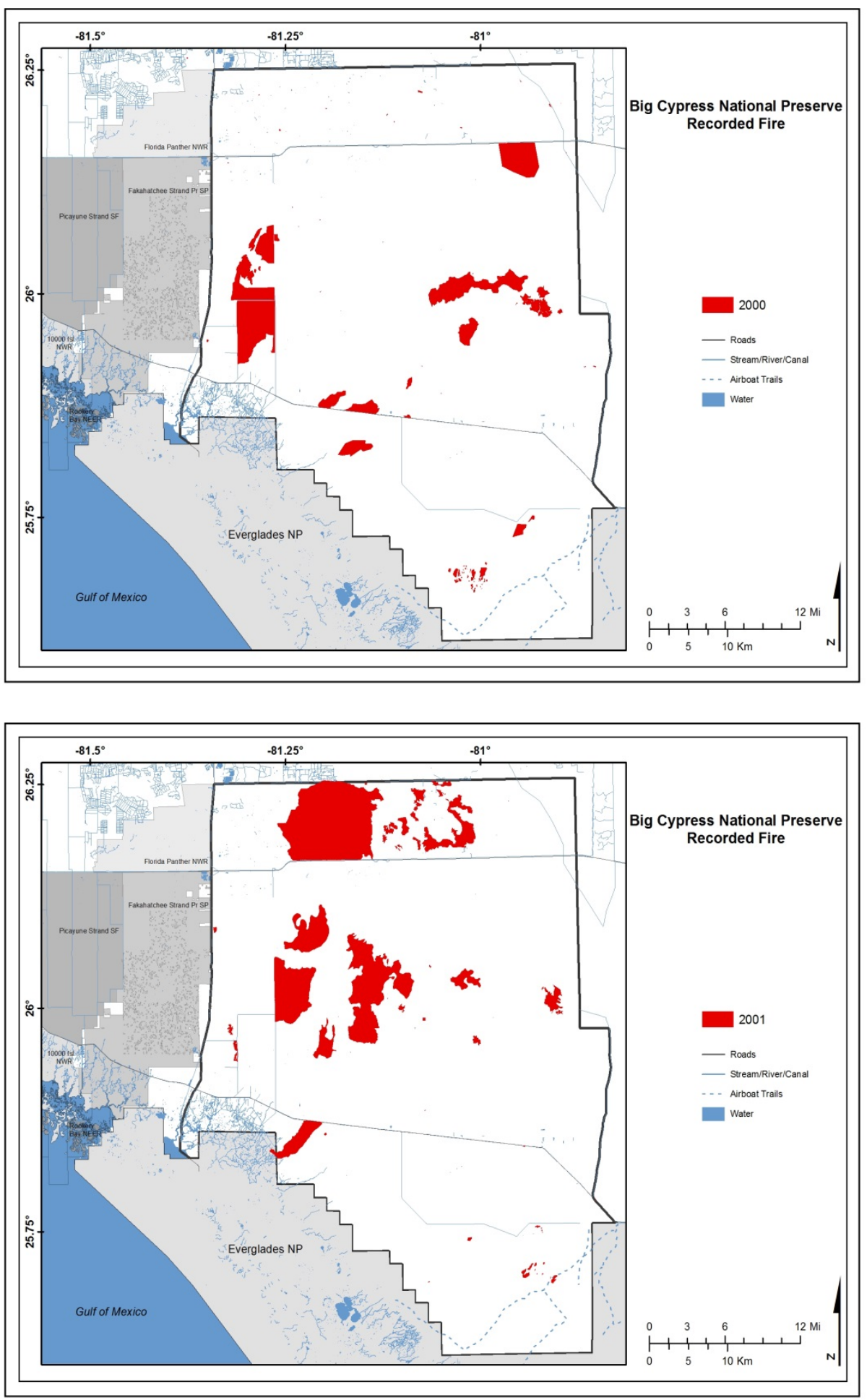

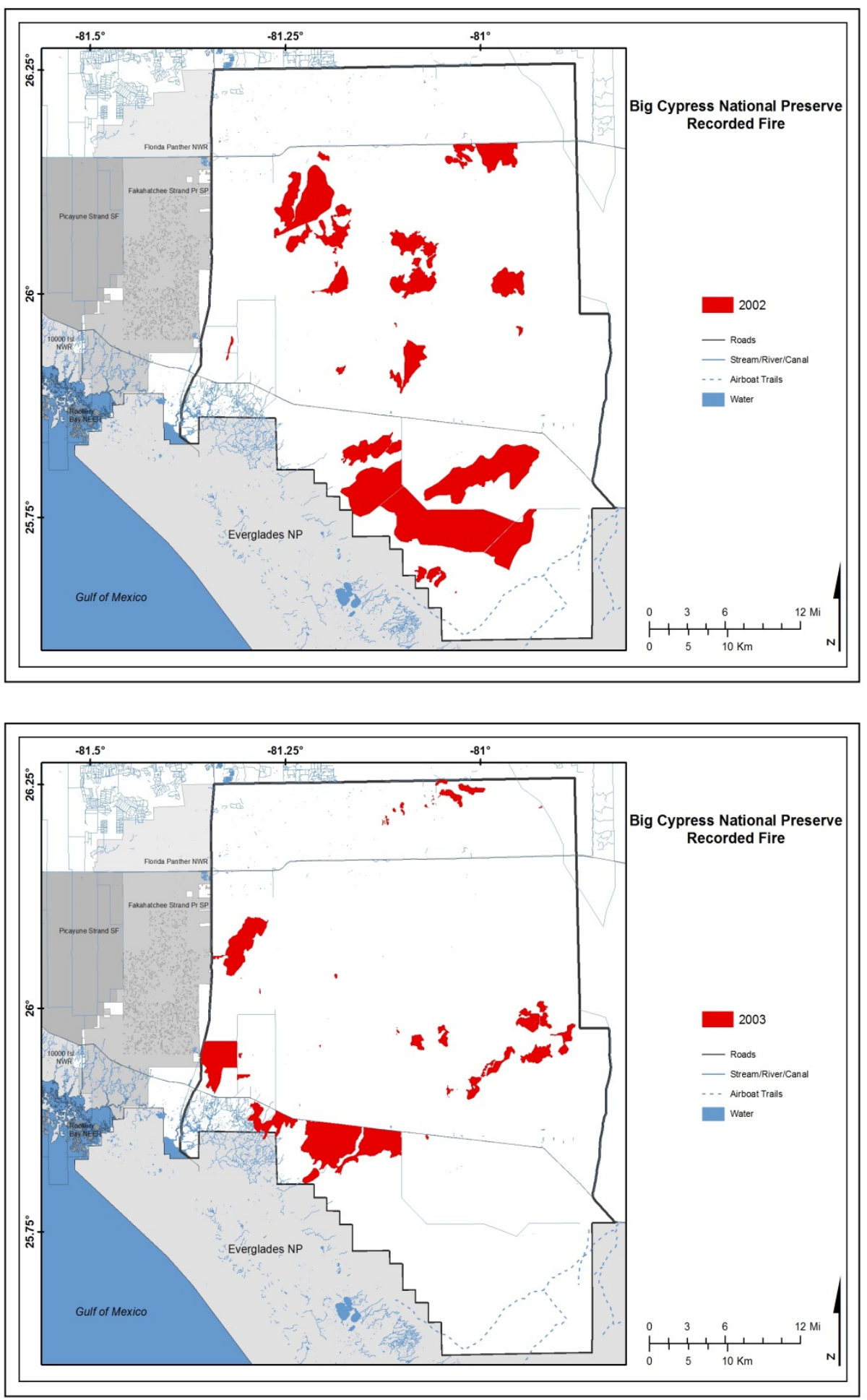

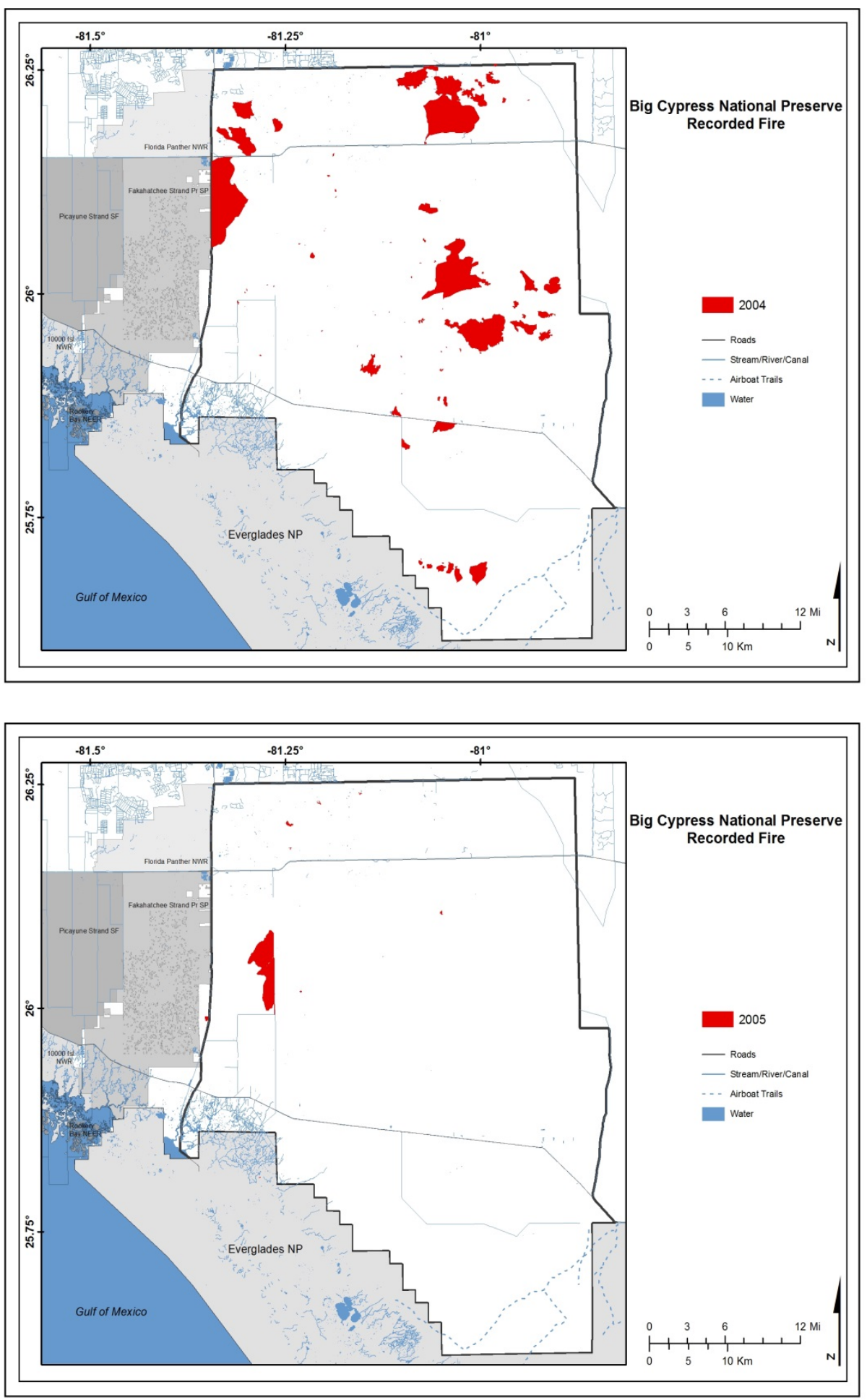

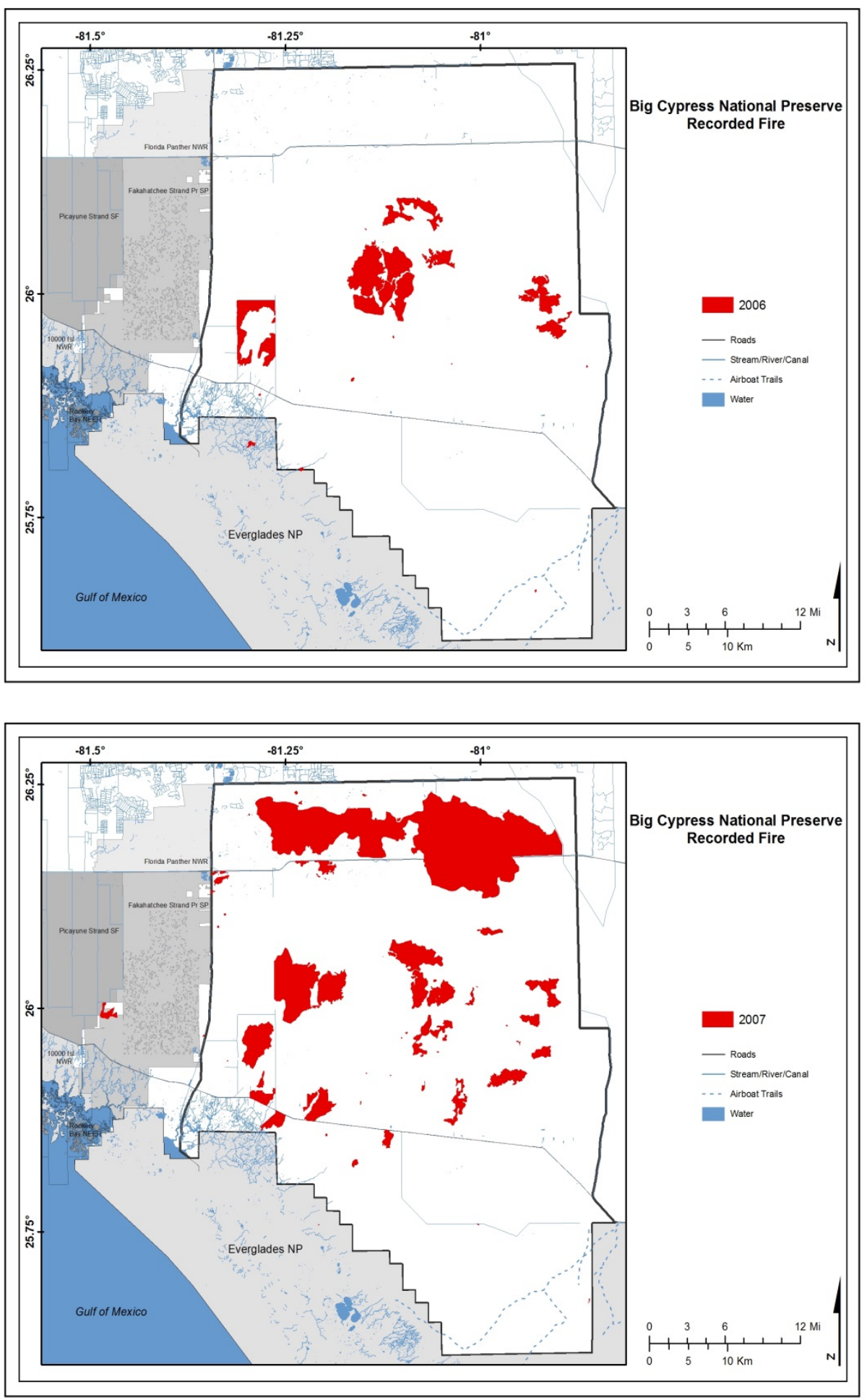

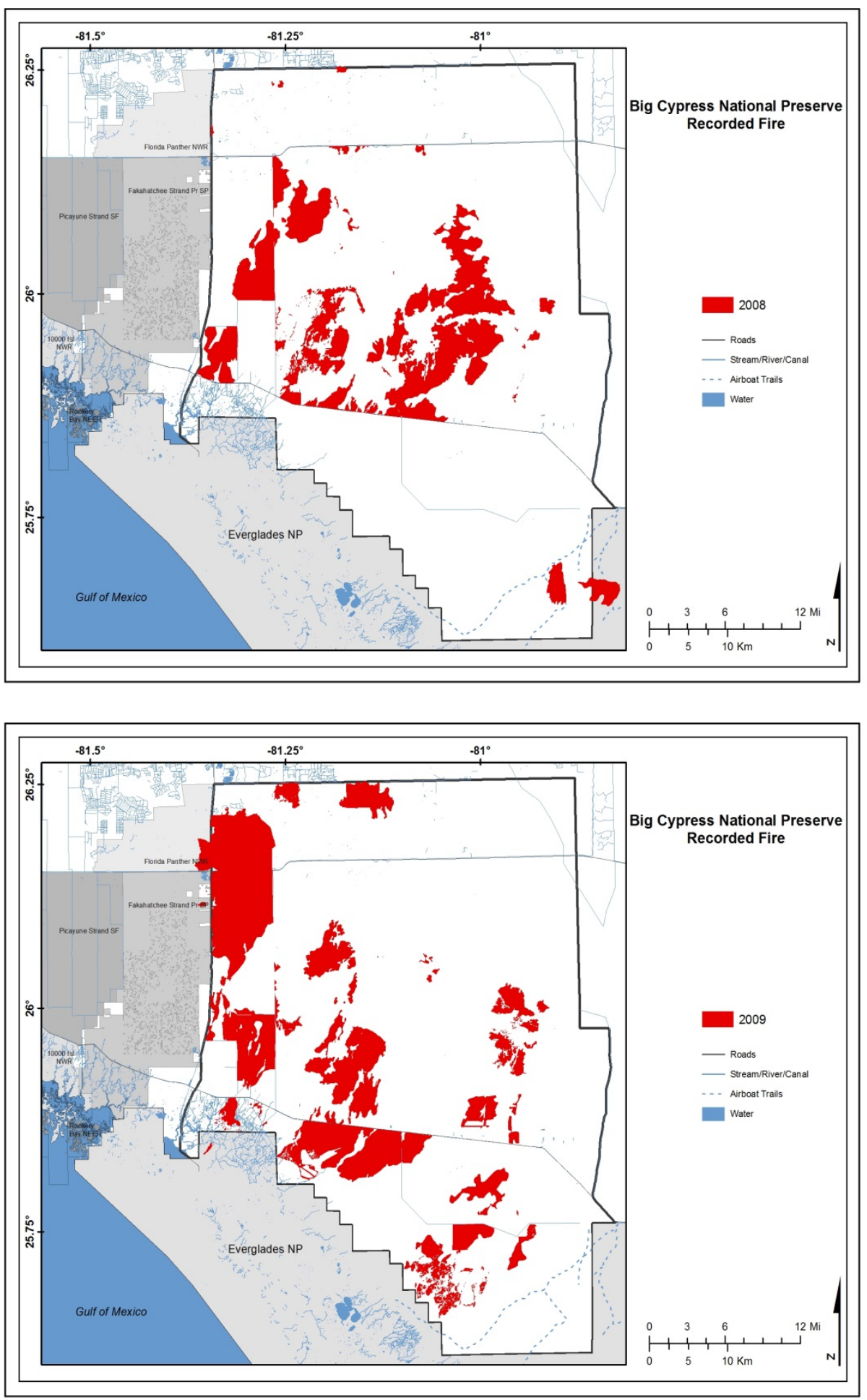


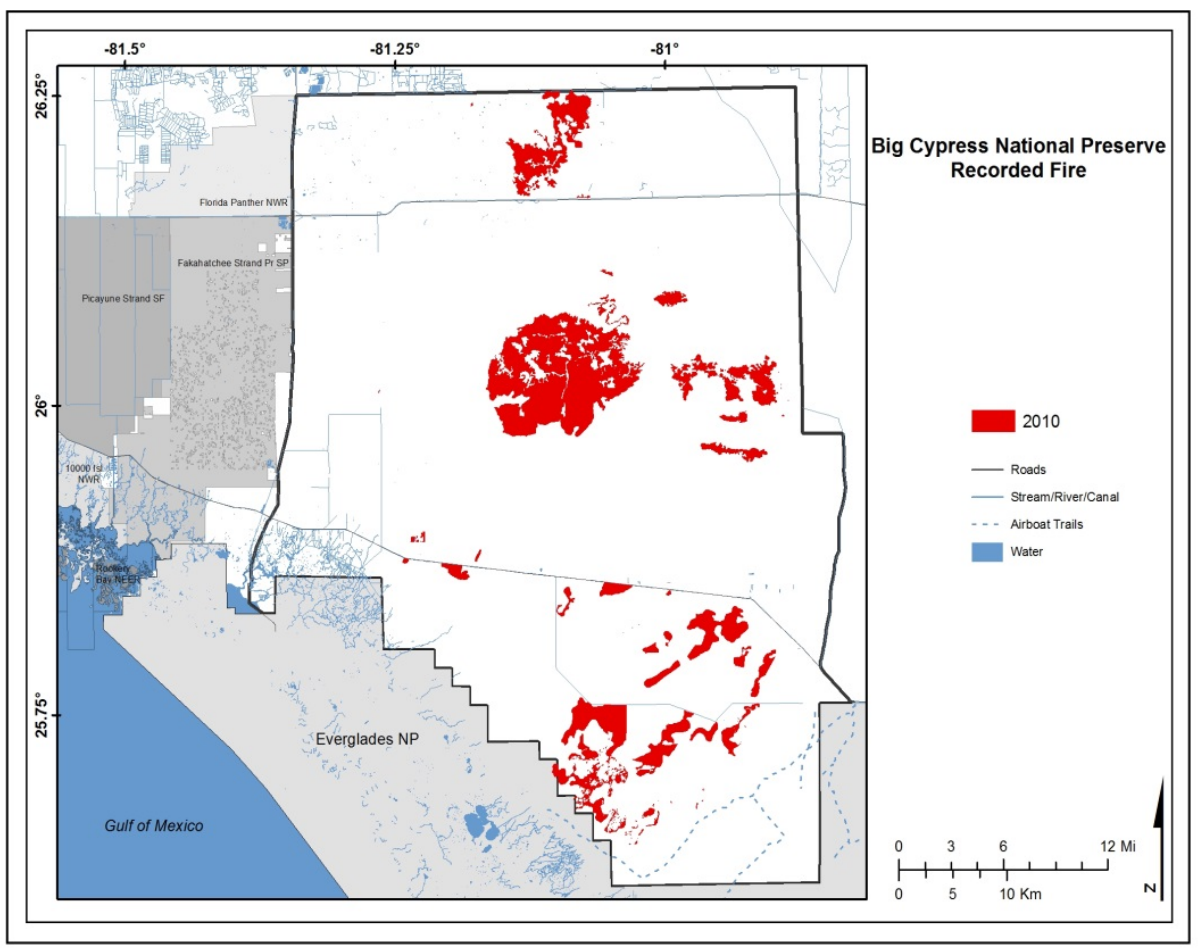




\section{Appendix C. Proposed National Park Service Spatial Data Standards for Fire History}

(April 3, 2003)

Layer Name: $\quad$ Polygons $-<$ park $>$ fire_pl (ie. glacfire_pl; shenfire_pl)

Points - <park $>$ fire_pt (ie. denafire_pt; sekifire_pt)

Layer Description: Fire History points represent the location at which fires began. The time span represented in the coverage or shapefile should be as complete as possible.

Fire History polygons represent final mapped wildland fire perimeters. These data are maintained at the Park level to track the area affected by fire. In the coverage format, polygon perimeters are stored via a regions feature class due to overlapping fire perimeters.

References: $\quad$ NPS Edited Version, DI-1202, Individual Fire Report (12/1994) "Instructions For Completing National Park Service Edited Version of DI-1202, Individual Fire Report.” December 14, 1994.

SACS - Shared Applications Computer System

FEAT - Fire Effects Application Tool

Spatial Data Source: Best available source with a target scale of 1:24,000 for Continental U.S., Puerto Rico, and Hawaii and 1:63,360 for Alaska.

Horizontal Accuracy: Targeted to National Map Accuracy Standards (NMAS).

Projection:

Unit appropriate. Include projection information.

Datum:

Unit appropriate. Include projection information.

Units of Measure: Unit appropriate. Include appropriate units for projection selected.

Feature Type:

Region Subclasses

File Type:

Point, Polygon, Region

Name: fires

Arc/Info coverage or shapefile

Note: The term Unit applies to a National Park Service Management Unit such as a National Park, a National Preserve or a National Monument. 
Fire History Points -INFO Attribute Tables (Arc/Info Coverage)

\begin{tabular}{|r|l|r|r|r|r|l|}
\hline COLUMN & ITEM NAME & \multicolumn{1}{l|}{ WIDTH } & OUTPUT & \multicolumn{1}{c|}{ TYPE } & N.DEC & ALTERNATE NAME \\
\hline 1 & AREA & 8 & 18 & F & 5 & \\
\hline 9 & PERIMETER & 8 & 18 & F & 5 & \\
\hline 17 & $<$ PARK>FIRE\# & 4 & 5 & B & - & \\
\hline 21 & $<$ PARK>FIRE-ID & 4 & 5 & B & - & \\
\hline 25 & FIRE_ID & 17 & 17 & C & - & \\
\hline 42 & UNIT_ID & 7 & 7 & C & - & \\
\hline 49 & YEAR & 4 & 4 & I & - & \\
\hline 53 & FIRE_NUM & 4 & 4 & C & - & \\
\hline 57 & FIRE_TYPE & 2 & 2 & I & - & \\
\hline 59 & GEN_CAUSE & 1 & 1 & I & - & \\
\hline 60 & SPEC_CAUSE & 2 & 2 & I & - & \\
\hline 62 & FIRE_NAME & 30 & 30 & C & - & \\
\hline 92 & AREA_NAME & 4 & 4 & C & - & \\
\hline 96 & OWNER & 1 & 1 & I & - & \\
\hline 97 & DISC_DATE & 8 & 8 & D & - & \\
\hline 105 & CNTRL_ACRE & 10 & 10 & N & 2 & \\
\hline 115 & DECLD_DATE & 8 & 8 & D & - & \\
\hline
\end{tabular}

Fire History Points -.DBF Tables (Shapefile)

\begin{tabular}{|l|r|l|r|r|}
\hline \multicolumn{1}{|c|}{ ITEM NAME } & \multicolumn{1}{|c|}{ WIDTH } & \multicolumn{1}{c|}{ TYPE } & N.DEC & ALTERNATE NAME \\
\hline SHAPE & 8 & SHAPEPOINT & & \\
\hline ID & 8 & N & & \\
\hline FIRE_ID & 17 & C & - & \\
\hline UNIT_ID & 7 & C & - & \\
\hline YEAR & 4 & N & - & \\
\hline FIRE_NUM & 4 & C & - & \\
\hline FIRE_TYPE & 2 & N & - & \\
\hline GEN_CAUSE & 1 & N & - & \\
\hline SPEC_CAUSE & 2 & N & - & \\
\hline FIRE_NAME & 30 & C & - & \\
\hline AREA_NAME & 4 & C & - & \\
\hline OWNER & 1 & N & - & \\
\hline DISC_DATE & 8 & D & - & \\
\hline CNTRL_ACRE & 10 & N & 2 & \\
\hline DECLD_DATE & 8 & D & - & \\
\hline
\end{tabular}


Fire History Polygons -INFO Attribute Tables (Arc/Info Region Coverage)

\begin{tabular}{|r|l|r|r|l|r|l|}
\hline COLUMN & ITEM NAME & \multicolumn{1}{|l}{ WIDTH } & OUTPUT & TYPE & N.DEC & ALTERNATE NAME \\
\hline 1 & AREA & 8 & 18 & F & 5 & \\
\hline 9 & PERIMETER & 8 & 18 & F & 5 & \\
\hline 17 & FIRES\# & 4 & 5 & B & - & \\
\hline 21 & FIRES-ID & 4 & 5 & B & - & \\
\hline 25 & FIRE_ID & 17 & 17 & C & - & \\
\hline 42 & UNIT_ID & 7 & 7 & C & - & \\
\hline 49 & YEAR & 4 & 4 & I & - & \\
\hline 53 & FIRE_NUM & 4 & 4 & C & - & \\
\hline 57 & FIRE_TYPE & 2 & 2 & I & - & \\
\hline 59 & GEN_CAUSE & 1 & 1 & I & - & \\
\hline 60 & SPEC_CAUSE & 2 & 2 & I & - & \\
\hline 62 & FIRE_NAME & 30 & 30 & C & - & \\
\hline 92 & AREA_NAME & 4 & 4 & C & - & \\
\hline 96 & OWNER & 1 & 1 & I & - & \\
\hline 97 & DISC_DATE & 8 & 8 & D & - & \\
\hline 105 & CNTRL_ACRE & 10 & 10 & N & 2 & \\
\hline 115 & DECLD_DATE & 8 & 8 & D & - & \\
\hline
\end{tabular}

Fire History Polygons -.DBF Tables (Shapefile)

\begin{tabular}{|l|r|l|r|l|}
\hline \multicolumn{1}{|c|}{ ITEM NAME } & \multicolumn{1}{c|}{ WIDTH } & \multicolumn{1}{c|}{ TYPE } & N.DEC & ALTERNATE NAME \\
\hline SHAPE & 8 & SHAPEPOLY & & \\
\hline ID & 8 & N & & \\
\hline FIRE_ID & 17 & C & - & \\
\hline UNIT_ID & 7 & C & - & \\
\hline YEAR & 4 & N & - & \\
\hline FIRE_NUM & 4 & C & - & \\
\hline FIRE_TYPE & 2 & N & - & \\
\hline GEN_CAUSE & 1 & N & - & \\
\hline SPEC_CAUSE & 2 & N & - & \\
\hline FIRE_NAME & 30 & C & - & \\
\hline AREA_NAME & 4 & C & - & \\
\hline OWNER & 1 & N & - & \\
\hline DISC_DATE & 8 & D & 2 & \\
\hline CNTRL_ACRE & 10 & N & - & \\
\hline DECLD_DATE & 8 & D & & \\
\hline
\end{tabular}


Domain for INFO tables: NPS Fire History Layer (Polygons)

ITEM NAME: Description

Valid Values

Value Description

FIRE_ID: Unique ID for each fire; created by concatenating [UNIT_ID] + [YEAR] + [FIRE_NUM]

\begin{tabular}{l|l}
\hline Example: AK-DEP-2001-0001 & Description: Unique ID for each fire
\end{tabular}

UNIT_ID: Interagency unit identifier; comprised of 2 letter state abbreviation and 3 letter unit abbreviation

\begin{tabular}{|l|l}
\hline Example: AK-DEP & Denali National Park and Preserve \\
\hline
\end{tabular}

YEAR: Year in which fire started; Item 3c on NPS edited version, DI-1202 Individual Fire Report (12/1994);

Referenced as CALENDAR YEAR in SACS

Example: 2001

Description: Year in which fire started

FIRE_NUM: Local Unit Fire Number; Item 3d on NPS edited version, DI-1202 Individual Fire Report

(12/1994); Referenced as FIRE NUMBER in SACS

Example: 0001

Description: Fire Number

FIRE_TYPE: Fire Type (1st digit) concatenated with Protection Type (2nd digit) as recorded on DI-1202 report; Item 4 on NPS edited version, DI-1202 Individual Fire Report (12/1994); Referenced as FIRE TYPE in SACS

Example: 11

Description: See document "Instructions For Completing National Park Service Edited Version of DI-1202, Individual Fire Report." December 14, 1994.

GEN_CAUSE: General Cause of fire; Item 5 (first number) on NPS edited version, DI-1202 Individual Fire Report (12/1994); Referenced as GENERAL CAUSE in SACS

\begin{tabular}{|l|l|}
\hline 1 & Natural \\
2 & Campfire \\
4 & Smoking \\
5 & Debris Burning \\
6 & Incendiary \\
7 & Equipment Use \\
8 & Railroads \\
9 & Children \\
& Miscellaneous \\
& \\
\hline
\end{tabular}


SPEC_CAUSE: Specific Cause of fire; Item 5 (second number) on NPS edited version, DI1202 Individual Fire Report (12/1994); Referenced as SPECIFIC CAUSE in SACS

Example: 1

Description: See document "Instructions For Completing National Park Service Edited Version of DI-1202, Individual Fire Report." December 14, 1994.

FIRE_NAME: Name of fire; Item 9a on NPS edited version, DI-1202 Individual Fire Report (12/1994);

Referenced as FIRE NAME in SACS

Example: Herron River

Description: Name of fire

AREA_NAME: Four Letter Park/Area Alpha code; Item 9b on NPS edited version, DI-1202 Individual Fire Report (12/1994); Referenced as AREA NAME in SACS

Example: DENA

Denali National Park and Preserve

OWNER: Land Owner at the point of origin for the fire; Item 9f on NPS edited version, DI1202 Individual Fire Report (12/1994); Referenced as OWNER in SACS

\begin{tabular}{l|l}
\hline 1 & BLM \\
2 & BIA \\
3 & NPS \\
4 & FWS \\
5 & USFS \\
6 & OTHER FED LAND \\
7 & STATE \\
8 & PRIVATE \\
9 & OTHER
\end{tabular}

DISC_DATE: Date the fire was discovered (YYYYMMDD); Item 10a (Date) on NPS edited version, DI-1202 Individual Fire Report (12/1994); Referenced as DATE DISCOVERED in SACS

Note: Neither the NPS edited version, DI-1202 Individual Fire Report (12/1994) or SACS requests the fire's discover date in (YYYYMMDD) format. Dates recorded on the DI-1202 report or entered into SACS will have to be reformatted to the (YYYYMMDD) format.

Example: 20010626

Description: Date fire discovered; (YYYYMMDD)

CNTRL_ACRE: Size in acres, to the nearest tenth acre (rounded up), at the time the fire was declared under control; Item 10c (Acres) on NPS edited version, DI-1202 Individual Fire Report (12/1994); Referenced as ACRES CONTROLLED in SACS

Example: 6238.20

Size of fire at the time was declared under control

DECLD_DATE: Date the fire was declared out (YYYYMMDD); Item 10d on NPS edited version, DI-1202 Individual Fire Report (12/1994); Referenced as DATE DECLARED OUT in SACS 
Note: Neither the NPS edited version, DI-1202 Individual Fire Report (12/1994) or SACS

requests the date the fire was declared out in (YYYYMMDD) format. Dates recorded on the

DI-1202 report or entered into SACS will have to be reformatted to the (YYYYMMDD)

format.

Example: 20010812

Description: Date fire was declared out;

(YYYYMMDD) 


\section{Appendix D. Fire Project Information and Data Entry Protocol}

Shape:

- SHAPE indicated what kind of a polygon we will be creating in the GIS.

- If the fire record includes a map denoting an irregular polygon, then that mapped polygon is considered to be the record of the Perimeter. Thus, the shape would be IRREGULAR POLYGON.

- If there is a map denoting the location of the fire, but the fire is an acre or less, then the shape is REGULAR CIRCLE and centered on the ignition point.

- If there is no map, but the fire is greater than one acre, the shape is a REGULAR SQUARE and centered on the ignition point.

- If there is no map or location information included in the record (no Lat/Long or UTMs or TRS), then enter RECORD (NO SHAPE) in the SHAPE column.

- The Individual Fire Report Instructions can be accessed at found at http://nctc.fws.gov/resources/knowledge-resources/Pubs9/fire_rpt_inst.pdf

Fire Identification:

- FIRE_ID is a combination of the UNIT_ID, YEAR, and FIRE_NUM. Enter a hyphen between each of the three name components.

Unit Identification:

- UNIT_ID will always be FL-EVR for Everglades fires.

Fire Type:

- FIRE_TYPE - This number is a combination of Fire Type (Page 4 of the Individual Fire Report Instructions) and Protection Type (Page 5 of the Individual Fire Report Instructions).

General and Specific Cases:

- GEN_CAUSE - may be listed specifically, but may need to obtain from report narration (Page 6 of the Individual Fire Report Instructions).

- SPEC_CAUSE - may be listed specifically, but may need to obtain from report narration (Page 6 of the Individual Fire Report Instructions).

Fire Name:

- FIRE_NAME - List the fire name exactly as it appears in the report.

Area Name:

- AREA_NAME - For Everglades fires this will always be EVER. For Big Cypress fires this will

Owner: always be BICY.

- OWNER - Owner type (Page 7 of the Individual Fire Report Instructions).

Discovery or Start Date:

- DISC_DATE - Date the fire started or was discovered. Format as numeric, "YYYYMMDD", with no spaces between the numbers. This is the date used for weather and water elevation data.

Acreage:

- CNTRL_ACRE - Number of acres burned by the fire.

Declared Out or Under Control Date:

- DECLD_DATE - Date the fire is declared out or under control. If there is no "Declared Out" date but it is obvious from the narrative that the fire was under control and crews left the scene, use the last day of firefighting as the "Declared Out" date.

Park Fire Number: 
- PARK_FIRE_NUM - If there is another number listed in the record as the fire number, list it here. This will help keep track of any discrepancies in the fire numbering or naming.

Remarks or Comments:

- REMARKS - Any judgment calls you may make about the data need to be noted under the REMARKS column.

- Particularly unusual data about the fire should be entered here.

- Enter notations about the record, such as if the record is a duplicate or if there are two copies if one record.

- Note if the fire record is that of a fire located out of state.

- Note the units of fire cost (per acre, total cost, etc.)

Account:

- ACCOUNT - The account to which any charges for the fire were made. May also be listed under "Fiscal Data" or similar title.

Fire Cost:

- FIRE_COST - The dollar amount that the fire cost, or was charged to another party. May format the column as Numeric with two decimal places. Please note in REMARKS if the cost was per acre, total cost of the fire, etc.

NORTHING and EASTING - Projection and Datum Information:

- Use UTM Zone 17N, NAD83 as the spatial projection and datum.

Weather Data:

NOTE: Do not enter predicted data, only enter actual recorded observations or data from Web sites that include actual data and time data.

- Use the Discovery/Start Date and Time of the fire as the date and time for which you obtain the weather data. Also, try to find the actual reported data, as some records include a weather forecast.

- RAW_STATION_ID - the ID number of one of the three weather stations in the Everglades that is closest to the fire location.

- If weather data not in file, obtain from: http://www.wrcc.dri.edu/wraws/flF.html

- WIND_SPEED - Use the maximum wind speed listed in the report or the Web site.

- TEMP - use dry bulb temperature

- $\mathbf{R H}$ - relative humidity

- KDBI - Keetch-Byram Drought Index ( $h$ ttp://www.freshfromflorida.com/Divisions-Offices/FloridaForest-Service/Wildfire/Keetch-Byram-Drought-Index-KBDI)

- WIND_DIR - Wind direction should be entered as text (N, NNE, W, S, etc.). If you are given a degree reading for wind direction, use the following list to determine the descriptive direction:

- N--- 0 deg to $11 \mathrm{deg}$ and/or $349 \mathrm{deg}$ to $360 \mathrm{deg}$

- NNE--- 12 deg to $33 \mathrm{deg}$

- NE--- $34 \mathrm{deg}$ to $56 \mathrm{deg}$

- ENE--- 57 deg to $78 \mathrm{deg}$

- E--- 79 deg to $101 \mathrm{deg}$

- ESE--- $102 \mathrm{deg}$ to $123 \mathrm{deg}$

- $\quad$ SE--- $124 \mathrm{deg}$ to $146 \mathrm{deg}$

- $\mathrm{SSE}---147 \mathrm{deg}$ to $168 \mathrm{deg}$

- S--- 169 deg to $191 \mathrm{deg}$

- $\mathrm{SSW}---192 \mathrm{deg}$ to $213 \mathrm{deg}$ 
- SW--- 214 deg to $236 \mathrm{deg}$

- WSW--- 237 deg to $258 \mathrm{deg}$

- W--- 259 deg to $281 \mathrm{deg}$

- WNW--- 282 deg to 303 deg

- NW--- 304 deg to 326 deg

- NNW--- 327 deg to $348 \mathrm{deg}$

Fire Behavior Data:

NOTE: Do not enter predicted data, only enter actual recorded observations.

- R_SPEED - Rate of fire spread in chains per hour (CPH). Only enter numeric values, do not enter descriptive values if that is all that is given. If the rate of spread is given in feet per minute, just multiply the value by 60 and then divide by 66 . This will give you rate of spread in chains per hour...66 feet $=1$ chain.

- DISP_INDEX - Smoke dispersion index

For more info: http://www.fl-dof.com/fire_weather/information/adi.html

- ONE_HR_FM - One our time lag fuel moisture

For more info: $h$ htp: $/ /$ new.forestencyclopedia.net $/ \mathrm{p} / \mathrm{p} 523$

- BURN_INDEX - index of fire severity

- FD_RATING - fire danger rating

- FLAME_LENGTH - use the maximum flame length given in the fire record (FEET).

- FUEL_MODEL - we will only use two models. Enter the code only.

- D1P3 - pine forest

- N1P3 - grassland

Staff Class:

- STAFF_CLASS - if listed in report, 1 is the lowest level, 5 is the highest level.

Water Elevation Data:

- This data is entered into the NP44_H2O_LVL column

- The data is obtained from the following link: http://sofia.usgs.gov/eden/station.php?stn_name=NP44\#datalinks

- Use Recent or Historic Hourly Data

- Find the date of your fire record (hint: use the search tool to find the date more quickly)

- The times are hourly. Use the closest hour to the start time/detection time of your fire. For example, if the fire started at 1425 , use 1400 . If it started at 1545 , use 1600. 
Publishing support provided by the U.S. Geological Survey Science Publishing Network, Tacoma Publishing Service Center

For more information concerning the research in this report, contact the Director, Southeast Ecological Science Center

U.S. Geological Survey

7920 NW 71st Street

Gainesville, Florida 32653

http://fl.biology.usgs.gov/ 


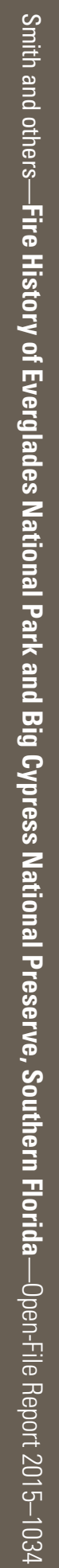

